A Portrait of

Prisoner Reentry

in Texas

Jamie Watson

Amy L. Solomon

Nancy G. La Vigne

Jeremy Travis

with Meagan Funches and Barbara Parthasarathy 


\section{Errata Sheet: A Portrait of Prisoner Reentry in Texas}

This is a listing of the substantive (non-grammatical) errors found in A Portrait of Prisoner Reentry in Texas (Watson, Solomon, La Vigne, and Travis 2004).

- Page $x$, first paragraph: the following sentence was added: “Texas's release patterns reflect these admissions and population trends: 58,949 prisoners were released from TDCJ prisons and state jails in 2002, nearly six times the number of prisoners released in $1980(10,636) . "$

- $\quad$ Page $\mathrm{x}$, second paragraph: changed 84 percent to 86 percent; changed 23 percent to 25 percent; and changed 57 percent to 47 percent.

- Page xi, first paragraph: changed 57 percent to 53 percent.

- $\quad$ Page xi, second paragraph: changed 59 percent to 58 percent.

- Page xiv, first paragraph: changed "...five times the number released two decades ago $(28,543$ in 1980)" to "more than five times the number released two decades ago $(10,636$ in 1980)."

- $\quad$ Page 3, figure 1.4: deleted the following note: "Release data after 1987 include prisoners released through parole in absentia (state prisoners paroled from non-TDCJ facilities); prior release data do not because the data are not available for those years" and changed the remaining note to include release data: "None of the admissions or release data include TDCJ prisoners who were admitted to county jails and completed their sentence there" (underline added here to highlight change).

- Page 12, first paragraph: changed 64 percent to 63 percent.

- $\quad$ Page 27, fourth paragraph: changed 30 percent to 35 percent.

- $\quad$ Page 29, fifth paragraph, changed 4 percent to 5 percent.

- $\quad$ Page 38, first paragraph, changed 1994 to 1992.

- Page 68, second paragraph, changed 135 to 113 and changed "return to all other zip codes in Houston" to "return to Houston."

- $\quad$ Page 77, second paragraph, changed 93 percent to 419 percent; changed 3.3 years to 3.4 years; changed 4.5 years to 4.6 years; and changed 57 percent to 47 percent.

- Page 77, third paragraph, changed 76 percent to 75 percent; changed 39 percent to 38 percent; and changed 61 percent to 62 percent.

- Page 86 , note 52, changed 33,410 to 33,428 and changed 59,572 to 58,949.

- Page 93 , note 161 , changed 34,410 to 33,428 and changed 59,572 to 58,949. 


\section{A Portrait of \\ Prisoner Reentry \\ in Texas}

Jamie Watson

Amy L. Solomon

Nancy G. La Vigne

Jeremy Travis

with Meagan Funches and Barbara Parthasarathy

\begin{tabular}{l|l|}
$\begin{array}{l}\text { Copyright @ 2004 } \\
\text { The Urban Institute }\end{array}$ & $\begin{array}{l}\text { The views expressed are those of the authors and should not be attributed to } \\
\text { The Urban Institute, its trustees, or its funders. The Justice Policy Center (JPC) } \\
\text { Jurricy Center }\end{array}$ \\
$\begin{array}{l}\text { carries out nonpartisan research to inform the national dialogue on crime, } \\
\text { Washington, DC 20037 } \\
\text { jww.urban. and community safety. For more information on JPC's reentry } \\
\text { research, visit http://jpc.urban.org/reentry. To receive monthly e-mail } \\
\text { (202) 833-7200 }\end{array}$ & $\begin{array}{l}\text { updates on JPC research, send an e-mail to JPC@ui.urban.org. } \\
\end{array}$
\end{tabular}




\section{About the Authors}

Jamie Watson is a research associate at the Urban Institute. Her primary areas of interest focus on prisoner reentry and community-based crime prevention and reduction initiatives. Ms. Watson's principal responsibility is project director for the Reentry Mapping Network, a partnership between the Urban Institute and local organizations committed to engaging neighborhoods by mapping and analyzing prisoner reentry at the neighborhood level. Ms. Watson has a master's degree in public policy from Harvard University and a B.A. in government from the University of Texas at Austin. Her master's thesis assessed the operational efficiencies of a community corrections program at the Suffolk County House of Correction in Boston; the analysis involved advanced statistical techniques and qualitative research. Ms. Watson is a native of Longview, Texas.

Amy L. Solomon is a policy associate at the Urban Institute, where she works to link the research activities of the Justice Policy Center to the policy and practice arenas. Her primary areas of concentration include prisoner reentry and problem-solving approaches to community safety. She currently manages the Reentry Roundtable series and the research partnerships with the Council of State Governments' Re-Entry Policy Council and the National Governors Association's Prisoner Reentry Policy Academy. She is currently working with several states and communities on their reentry planning efforts. Prior to joining the Urban Institute, Ms. Solomon served as policy analyst and acting director of strategic planning at the National Institute of Justice. Ms. Solomon obtained her master's degree in public policy from Harvard University and has a B.A. in English from the University of Michigan.

Nancy G. La Vigne is a senior research associate at the Urban Institute, where she directs several projects on prisoner reentry, including Returning Home: Understanding the Challenges of Prisoner Reentry, a multi-state, longitudinal study of the reentry experience. Prior to her current position, she was founding director of the National Institute of Justice's Crime Mapping Research Center. Dr. La Vigne obtained her Ph.D. in criminal justice from Rutgers University, a master's degree in public administration from the University of Texas at Austin, and a B.A. in political science from Smith College.

Jeremy Travis is a senior fellow at the Urban Institute. He is the cochair of the Reentry Roundtable, a group of prominent academics, practitioners, service providers, and community leaders working to advance policies and innovations on prisoner reentry that reflect solid research. Before joining the Urban Institute, Mr. Travis directed the National Institute of Justice, the research arm of the United States Department of Justice, from 1994 to 2000. Mr. Travis has been a key figure in the development of a policy and research agenda on the issue of prisoner reentry, including authoring the article "But They All Come Back: Rethinking Prisoner Reentry," developing the concept of the reentry court, and designing the reentry partnership initiative of the Department of Justice. He obtained his J.D. and a master's degree in public administration from New York University and his B.A. in American studies from Yale University.

Meagan Funches is a project associate at the Urban Institute. Her principal responsibility at the Urban Institute is providing research and policy support for the Justice Policy Center's many projects focused on prisoner reentry. Her primary areas of interest include the effect of incarceration on children and families. Ms. Funches has a B.A. in government from Harvard University.

Barbara Parthasarathy is a research associate at the Urban Institute. Her principal responsibility at the Urban Institute is as a criminal justice data analyst for the Federal Justice Statistics Resource Center, a widely used database of federal justice information compiled by the Urban Institute for the Bureau of Justice Statistics in the Department of Justice. Ms. Parthasarathy has a B.S. in geography from the University of Maryland. 


\section{Contents}

EXECUTIVE SUMMARY

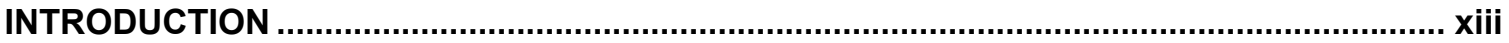

CHAPTER 1

WHAT IS THE POLICY CONTEXT SURROUNDING PRISONER REENTRY IN TEXAS? .......... 1

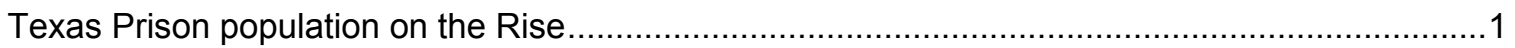

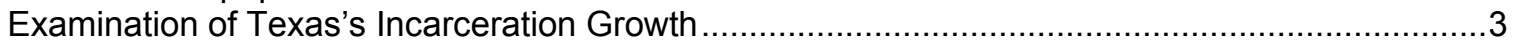

Summary

CHAPTER 2

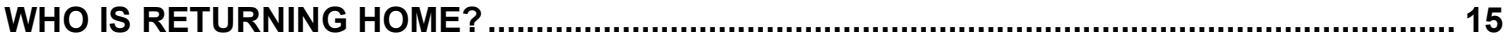

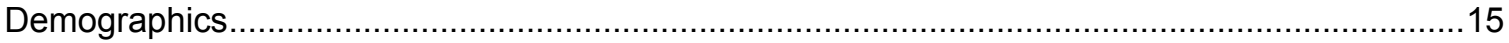

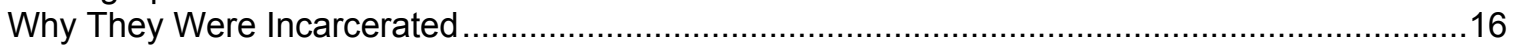

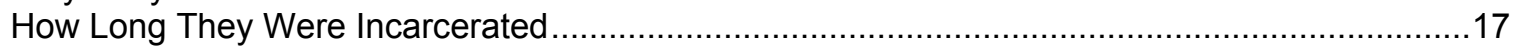

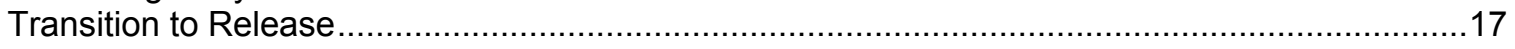

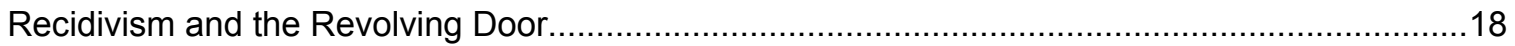

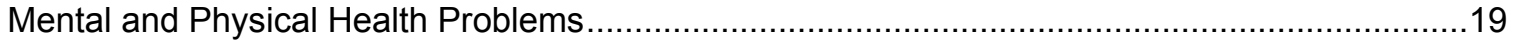

\section{CHAPTER 3}

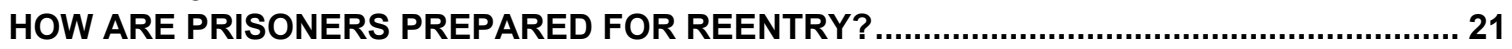

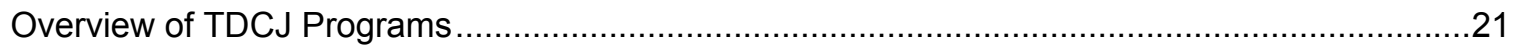

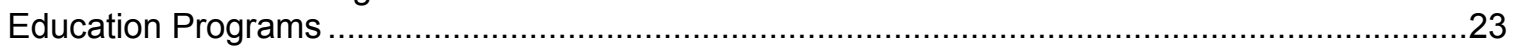

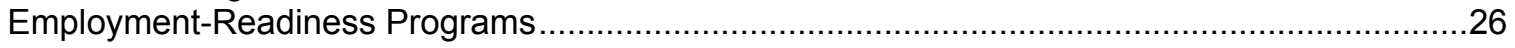

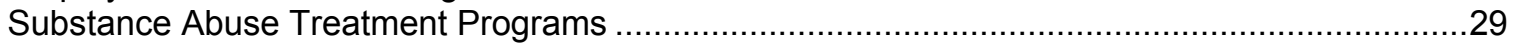

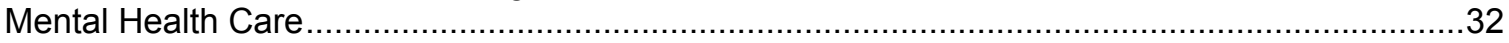

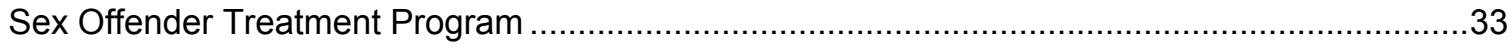

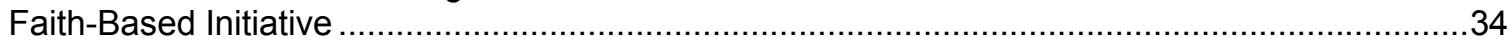

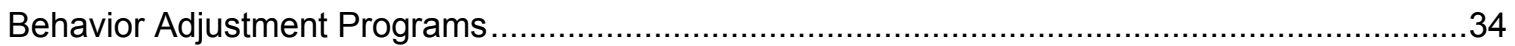

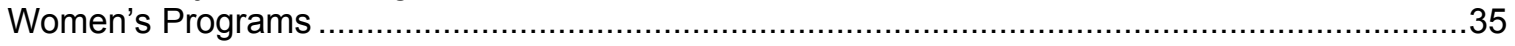

CHAPTER 4

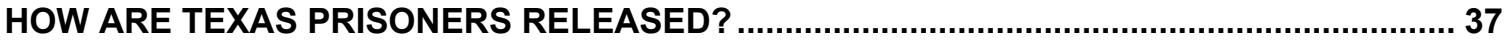

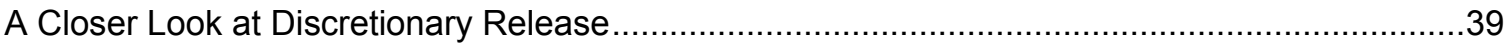

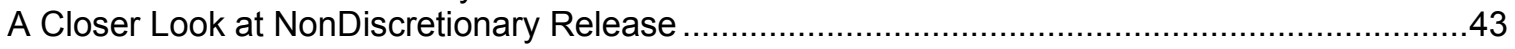

CHAPTER 5

HOW ARE TEXAS PRISONERS SUPERVISED UPON RELEASE? ..................................... 45

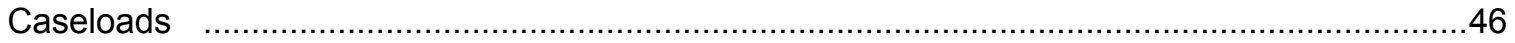

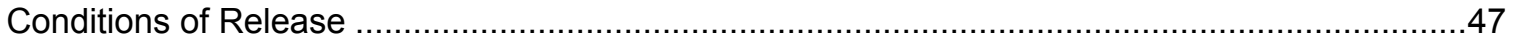

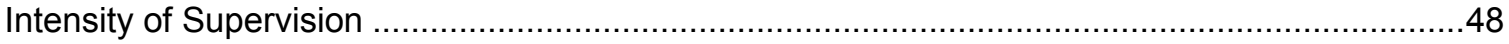

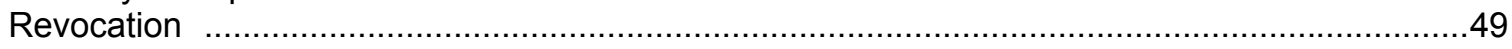

CHAPTER 6

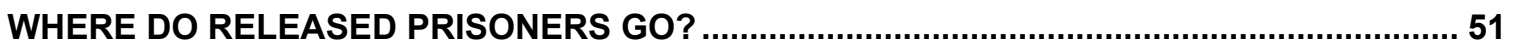

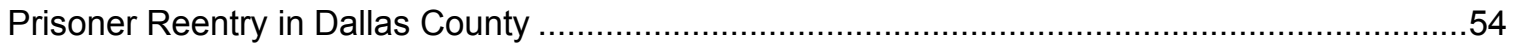

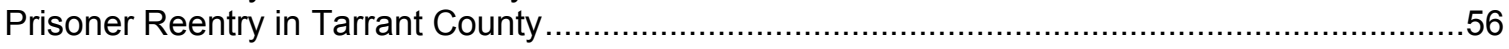

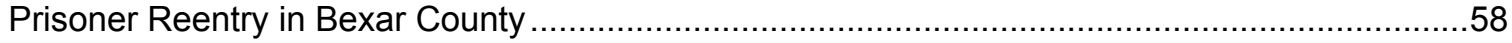

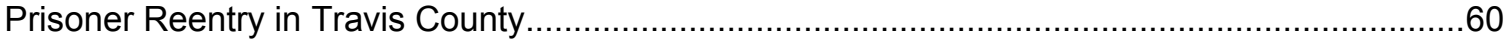

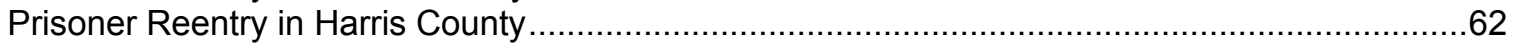


CHAPTER 7

TO WHICH HOUSTON NEIGHBORHOODS ARE TEXAS PRISONERS RETURNING? ........... 65

Overview of Released Prisoners who Returned to Houston ...............................................66

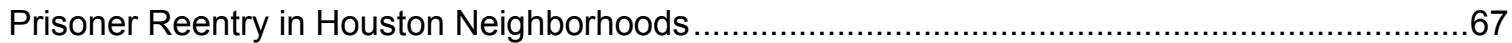

CHAPTER 8

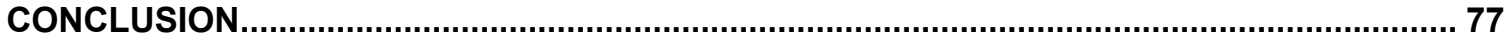

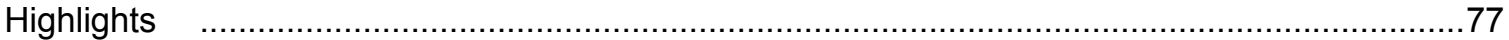

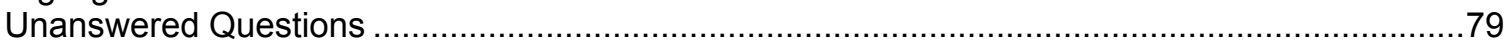

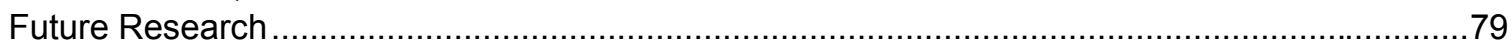

NOTES

APPENDIX A

CHARACTERISTICS OF EX-PRISONERS BY POSTRELEASE SUPERVISION ...................... 97

APPENDIX B

OVERVIEW OF PROBATION.

99 


\section{List of Figures}

CHAPTER 1

WHAT IS THE POLICY CONTEXT SURROUNDING PRISONER REENTRY IN TEXAS? .......... 1

Figure 1.1. TDCJ prison population, FY 1980 to FY 2002 ...............................................

Figure 1.2. Texas and U.S. incarceration rates (per 100,000 residents), FY 1980 to

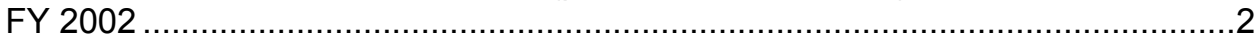

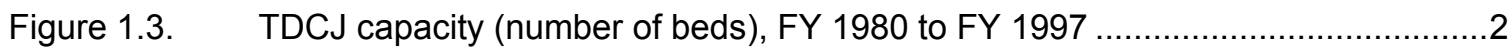

Figure 1.4. TDCJ admissions, TDCJ releases, and sentences to prison, FY 1980 to

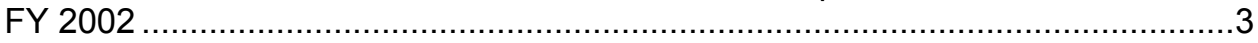

Figure 1.5. Time served by Texas releasees (in years), FY 1988 to FY 2002 ….................4

Figure 1.6. Convicted felons in county jails awaiting transfer to TDCJ, FY 1988 to

FY 2002 ..............................................................................................

Figure 1.7. Total Number of all reported crimes in Texas, FY 1988 to FY $2001 \ldots \ldots \ldots \ldots \ldots \ldots . . .5$

Figure 1.8. Total Number of reported violent crimes in Texas, FY 1988 to FY 2001 .............6

Figure 1.9. Total Number of reported property crimes in Texas, FY 1988 to FY 2001 ...........6

Figure 1.10. Adult (age 17 and older) arrests in Texas by select offense types,

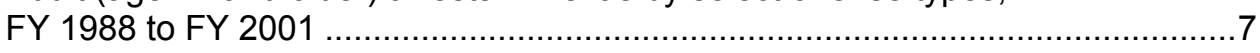

Figure 1.11. TDCJ admissions by offense type as a percentage of all admissions,

FY 1988 to FY 2002 ............................................................................. 8

Figure 1.12. Revocations as a share of TDCJ admissions, FY 1988 to FY 2002 ...................9

Figure 1.13. Sentence length (in years) of all TDCJ releases, FY 1988 to FY $2002 \ldots \ldots \ldots \ldots . . .10$

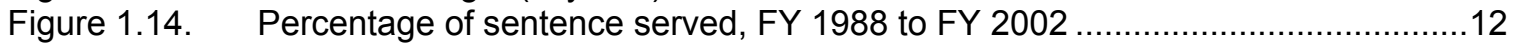

Figure 1.15. Parole approval rates, FY 1988 to FY 2002 .............................................12

Figure 1.16. Parole and mandatory supervision releases as percentage of all releases

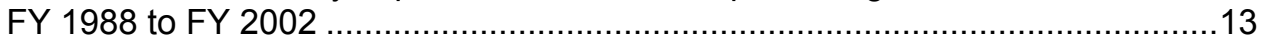

\section{CHAPTER 2}

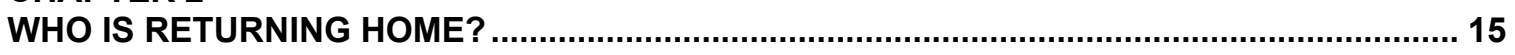

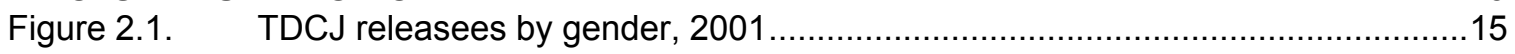

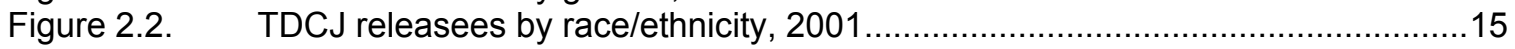

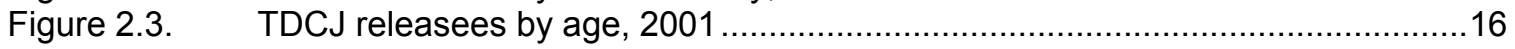

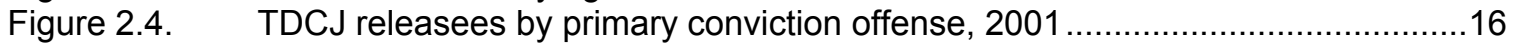

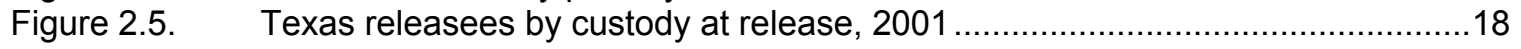

CHAPTER 3

HOW ARE PRISONERS PREPARED FOR REENTRY? ................................................ 21

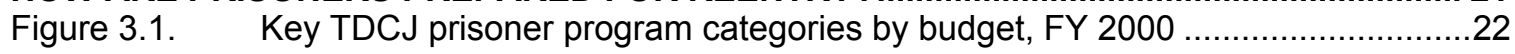

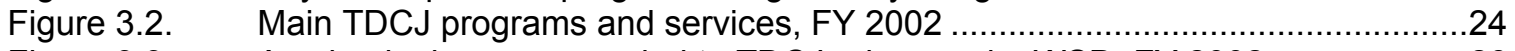

Figure 3.3. Academic degrees awarded to TDCJ prisoners by WSD, FY 2002 ..................26

CHAPTER 4

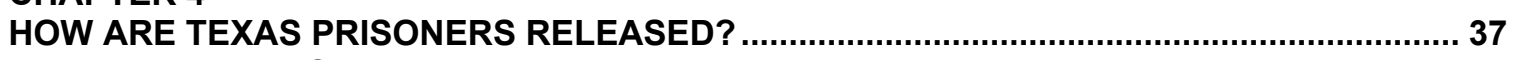

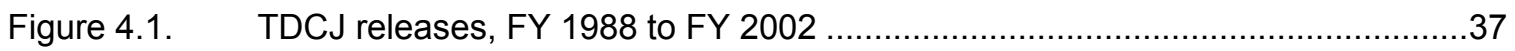

Figure 4.2. TDCJ discretionary and nondiscretionary releases as a percentage of all releases, FY 1988 to FY 2002 ...................................................................... 38

Figure 4.3. State prisoner and confinee discretionary releases as a percentage of all

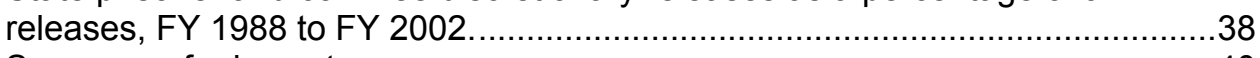

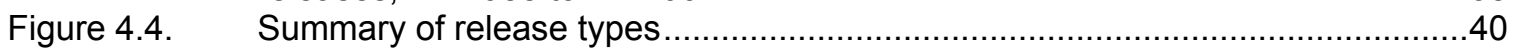


CHAPTER 5

HOW ARE TEXAS PRISONERS SUPERVISED UPON RELEASE?

Figure 5.1.

Percentage of all TDCJ releases released to supervision, FY 1988 to

FY 2002.

Figure 5.2.

Percentage of all released state prisoners and confinees released to

supervision, FY 1988 to FY 2002

Figure 5.3.

Figure 5.4.

Figure 5.5.

Active parole population in Texas, FY 1988 to FY 2002.

Texas parole facilities, capacity, and usage, FY 2002 ...................................48

Parole and mandatory supervision revocations as a percentage of all

TDCJ admissions, FY 1988 to FY 2002.

\section{CHAPTER 6}

WHERE DO RELEASED PRISONERS GO?

Figure 6.1 .

Figure 6.2.

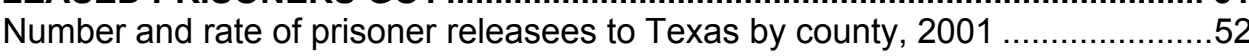

Figure 6.3.

Percentage of prisoner releasees to Texas by county, $2001 \ldots \ldots \ldots \ldots \ldots \ldots \ldots \ldots \ldots . . .53$

Figure 6.4.

Percentage of supervised releasees to Dallas County by zip code, 2001 ...........55

Offense types of Dallas County prisoner releasees and all Texas prisoner

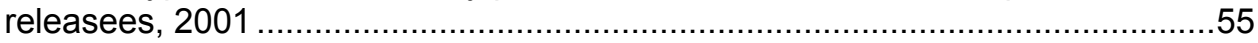

Figure 6.5.

Percentage of supervised releasees to Tarrant County by zip code, 2001 ........57

Figure 6.6.

Offense types of Tarrant County prisoner releasees and all Texas prisoner

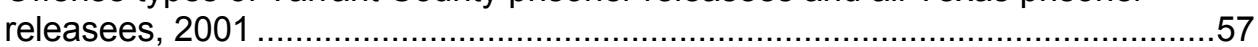

Figure 6.7. Percentage of supervised releasees to Bexar County by zip code, $2001 \ldots \ldots \ldots . . .59$

Figure 6.8.

Figure 6.9.

Offense types of Bexar County prisoner releasees and all Texas prisoner

releasees, 2001

Figure 6.10.

Percentage of supervised releasees to Travis County by zip code, 2001 ..........61

Offense types of Travis County prisoner releasees and all Texas prisoner

releasees, 2001

Figure 6.11.

Percentage of supervised releasees to Harris County by zip code, 2001

Figure 6.12.

Offense types of Harris County prisoner releasees and all Texas prisoner

releasees, 2001

CHAPTER 7

TO WHICH HOUSTON NEIGHBORHOODS ARE TEXAS PRISONERS RETURNING?

Figure 7.1.

Houston residents, Houston supervised releasees, and all TDCJ

releasees by race/ethnicity, 2001 .

Figure 7.2.

Houston supervised releasees and all TDCJ releasees by offense type,

2001.

Figure 7.3.

2001

(1)

Figure 7.4.

Numbers and rates of supervised releasees returning to Houston's

high-return zip codes, 2001

Figure 7.5.

Figure 7.6.

Rates of supervised releasees returning to Texas, Harris County, Houston, and Houston's high-return neighborhoods (per 1,000 residents), 2001 ..............69

Rank of Houston's seven high-return neighborhoods by demographic characteristic, 2001

Figure 7.7.

Rate of selected crimes (per 1,000 residents) by Houston neighborhoods,

2001

Figure 7.8

Percentage of residents below the federal poverty level by Houston

neighborhood, 2001

Figure 7.9.

Figure 7.10.

Figure 7.11.

Figure 7.12.

Percentage of female-headed households by Houston neighborhood,

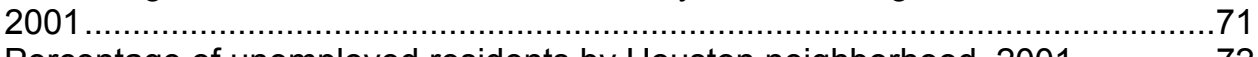

Percentage of unemployed residents by Houston neighborhood, 2001 ..............72

Percentage of renter-occupied housing by Houston neighborhood, 2001 ............72

Social services for Houston's high-return neighborhoods, 2001 .......................76

Figure 7.13.

Percentage of supervised releasees and services by Houston

neighborhoods, 2001 


\section{Acknowledgments}

The authors would like to thank the many individuals and organizations that made valuable contributions to this report. The Texas Department of Criminal Justice (TDCJ) provided the data that serve as the backbone for our analysis; specifically, we are grateful for the support and assistance of Gary Johnson, executive director of TDCJ; Dimitria Pope, director of the Research, Evaluation and Development Group; Michelle Moczygemba Connolly, assistant director of the Research, Evaluation and Development Group; Doug Dretke, director of the Correctional Institutions Division; Virginia Gibbons, program administrator II of the Parole Division's Information Services; Debbie Roberts, former director of the Programs and Services Division; Jeff Baldwin, senior executive assistant to the executive director; Wanda Redding, program administrator II of the Programs and Services Division; Travis Henderson, coordinator of Government Relations, Planning, and Evaluation of the Windham School District; and Gaylon Oswalt, former director of the Community Justice Assistance Division's Research Division. We are also grateful to many of these individuals for reviewing an early draft of this document. The Criminal Justice Policy Council also offered invaluable assistance in the early stages of the project by providing supplemental statistics, answering a myriad of questions about the corrections system in Texas, and reviewing an early version of this report. In particular, we would like to thank Tony Fabelo, former executive director; Andrew Barbee, former research specialist; and Mike Eisenberg, former senior research associate. Gratitude is also owed to Mike Lesco, deputy administrator of the Crime Records at the Texas Department of Public Safety. Elycia Daniel, from Sam Houston State University, collected the data on Houston-based services for returning prisoners. From the Urban Institute, we would like to thank Christy Visher, Sinead Keegan, Daniel P. Mears, and Megan Schaffer for providing critical feedback on earlier drafts of this report. We also thank the JEHT Foundation and the Houston Endowment for funding this project. Without them, this report would not have been possible. 


\section{Returning Home: Understanding the Challenges of Prisoner Reentry}

A Portrait of Prisoner Reentry in Texas is part of a larger Urban Institute initiative entitled Returning Home: Understanding the Challenges of Prisoner Reentry. The purpose of Returning Home is to develop a deeper understanding of the reentry experiences of returning prisoners, their families, and their neighborhoods. With support from the Texas Department of Criminal Justice, the Houston Endowment, and the JEHT Foundation, the Urban Institute has launched Returning Home in Texas. This research project involves interviews with state prisoners before and after their release from state correctional facilities, interviews with ex-prisoners' family members, focus groups with residents in neighborhoods to which many prisoners return, analysis of extant data on local indicators of community well-being, and interviews with community stakeholders. State laws and policies will also be reviewed to provide the overall political and policy context. The results of this research on reentry in Texas will be published in 2005 and will also be part of a larger cross-state analysis based on Returning Home research conducted in Maryland, Illinois, and Ohio. 


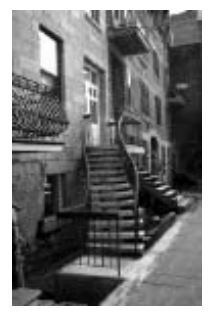

\section{Executive Summary}

$\mathrm{T}$ The growing number of prisoners - 55,183 in 2001returning to neighborhoods throughout Texas elevates the importance of prisoner reentry in the state. This report describes the process of prisoner reentry in Texas by examining the policy context surrounding reentry, the characteristics and geographic distribution of the state's returning prisoners, how prisoners are prepared for their release, the process by which they are released, how they are supervised once released, and the social and economic climates of the neighborhoods that are home to the largest numbers of returning prisoners. This report does not attempt to evaluate a specific reentry program nor does it empirically assess reentry policies and practices in Texas. Rather, the

\section{Note on Language}

"Confinees" are prisoners under the custody of TDCJ who have been convicted of a state jail felony offense and sentenced to no more than two years in a state jail. "State prisoners" are all other prisoners under the custody of TDCJ. In this report, the term "prisoner" represents all those persons under TDCJ custody, which includes both state prisoners and confinees. report consolidates existing data on incarceration and release trends and presents a new analysis of data on Texas prisoners released in 2001. The data used for this report were derived from several sources, including the U.S. Census Bureau, U.S. Bureau of Justice Statistics, Texas Department of Criminal Justice (TDCJ), Criminal Justice Policy Council, Texas Department of Public Safety, Houston Police Department, and City of Houston's Planning and Development Department. Highlights from the report follow.

Historical Incarceration and Release Trends. Texas's incarceration and reentry trends are similar to those observed at the national level. Between 1980 and 2001, the total number of prisoners in Texas increased fivefold, from 28,543 to 151,003 prisoners. In this period, the per capita rate of imprisonment in Texas rose 248 percent (from 199 to 693 prisoners per 100,000 residents), mirroring the 242 percent increase in the U.S. imprisonment rate (from 139 to 476 prisoners per 100,000 residents). The growth in Texas's prison population is largely attributable to rising prison admissions and longer lengths of stay in prison. Admissions increased primarily due to an increase in arrests for violent and drug crimes and an increase in the number of felony convictions. Prisoners were spending more time in prison mainly because most received longer 
sentences and were serving longer portions of their sentences (time served). Falling parole approval rates and legislation requiring prisoners to serve greater percentages of their sentences both contributed to the increase in time served. Texas's release patterns reflect these admissions and population trends: 58,949 prisoners were released from TDCJ prisons and state jails in 2002, nearly six times the number of prisoners released in $1980(10,636)$.

Profile of Prisoners Released in 2001. Approximately two-thirds $(36,538)$ of TDCJ prisoners released to Texas addresses were state prisoners and approximately one-third $(18,107)$ were confinees. Most were male (86 percent), and nearly half (44 percent) were non-Hispanic black, a third (32 percent) were non-Hispanic white, and 24 percent were Hispanic. The median age at release was 34 . The greatest share (39 percent) of TDCJ releases had been incarcerated for drug offenses; 33 percent had been incarcerated for property offenses; and 17 percent had been incarcerated for violent offenses. One-quarter had violated parole or mandatory supervision either by committing a new offense or a technical violation. The largest share (53 percent) of prisoners released in 2001 had served less than two years in state correctional facilities, and the next largest share (25 percent) had served more than five years. State prisoners were incarcerated, on average, for 4.6 years after serving 47 percent of their sentences. Confinees were incarcerated, on average, for 11 months after serving 100 percent of their sentences.

How Prisoners Are Prepared for Release. In 2002, most TDCJ prisoners participated in work activities, a substantial proportion participated in work-readiness and education programs, and few are documented to have participated in vocational or formal substance abuse treatment programs. TDCJ reports that 85 percent of all prisoners are participating in work activities at any given time, and 69,506 prisoners (35 percent of potential participants) participated in Project Rio-TDCJ's main work-readiness program. Approximately 83,337 prisoners participated in basic educational programs (approximately 42 percent of possible participants), and 12,463 (6 percent of possible participants) participated in college-level courses and vocational classes. At least 9,000 prisoners (5 percent of potential participants) were admitted to TDCJ's formal substance abuse programs prior to release, and at least 8,700 prisoners participated in postrelease inpatient substance abuse programs. Additional prisoners reportedly participated in substance abuse programs, but participation rates for many programs were unavailable.

How Prisoners Are Released. In 2001, 62 percent of Texas prisoners were released through nondiscretionary means (i.e., mandatory release or expiration of sentence). Of the remaining 38 percent, nearly all were released through the approval of the Board of Pardons and Paroles. Most state prisoners were released through a parole board decision; confinees are ineligible for this type of release. The number of prisoners released by a parole board decision has decreased dramatically over the past decade. 
Life on the Outside: Parole and Probation Supervision. In 2001, more than half (53 percent) of released prisoners were subject to parole supervision after release (whether released through parole or mandatory supervision), and 2 percent were subject to felony probation supervision after release. While most state prisoners are eligible for postrelease supervision through parole or mandatory supervision, no confinees are. Thus, most ( 84 percent) state prisoners are subject to postrelease supervision, compared with less than 3 percent of confinees.

Geographic Distribution of Released Prisoners. The vast majority (99 percent) of Texas prisoners released in 2001 were released to Texas communities. Over half (58 percent) returned to 5 of Texas's 254 counties. A quarter (26 percent, or 14,129 prisoners) returned to Harris County, 15 percent (7,971 prisoners) returned to Dallas County, 8 percent (4,097 prisoners) returned to Tarrant County, 6 percent (3,156 prisoners) returned to Bexar County, and 4 percent (2,342 prisoners) returned to Travis County. Examining returns at a more localized level, the largest share (23 percent) of supervised releasees returned to the city of Houston, which is located in Harris County (return zip codes are unavailable for prisoners not released to supervision). Within Houston, these releasees are most heavily concentrated in 5 of the city's 185 zip codes, and these zip codes span seven neighborhoods: Alief, East Houston, East Little York/Homestead, Kashmere Gardens, Trinity/Houston Gardens, Third Ward, and MacGregor. Each of these neighborhoods received more than 200 supervised releasees in 2001, more than returned to some entire counties in Texas. It should be noted that the presence of a halfway house in East Houston may explain the large number of releases returning to that zip code. High levels of poverty and crime also characterize most of these neighborhoods. 



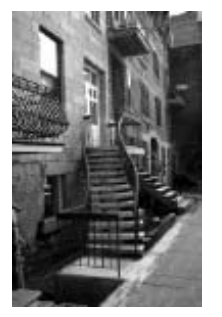

\section{Introduction}

$\mathrm{T}$

This report examines prisoner reentry in the state of Texas. Prisoner reentry - the process of leaving state correctional facilities and returning to society-has become a pressing issue both in Texas and nationwide. Rising incarceration rates over the past quarter century have resulted in more and more prisoners being released from prison each year. Nationally, an estimated 630,000 prisoners were released from state and federal prisons in 2001, a fourfold increase over the past two decades. ${ }^{1}$ Thus, released prisoners, their families, and the neighborhoods to which they return must cope with the challenges of reentry on a much greater scale than ever before.

And the challenges of reentry are many indeed. More prisoners nationwide are returning home having spent longer terms behind bars than in the past, exacerbating the already significant challenges of finding employment and reconnecting with family. ${ }^{2}$ Prisoners today are typically less prepared for reintegration, less connected to community-based social structures, and more likely to have health or substance abuse problems than in the past. ${ }^{3}$ In addition to these personal circumstances, limited availability of jobs, housing, and social services in a community may affect the returning state prisoner's ability to successfully reintegrate. ${ }^{4}$

These challenges affect more than returning prisoners and their families; they can also have serious public safety implications for the neighborhoods to which prisoners return. Reentry concerns are most pressing in major metropolitan areas across the country, to which about twothirds of the state prisoners released in 1996 returned - up from 50 percent in $1984 .{ }^{5}$ Within central cities, released prisoners may be even more concentrated in a few neighborhoods. ${ }^{6}$ These high concentrations of returning prisoners may generate substantial costs to those neighborhoods, including increases in crime, greater public health risks, and high rates of unemployment and homelessness. Developing a thorough understanding of the characteristics of returning state prisoners and the challenges they face is an important first step in shaping public policy toward improving the safety and welfare of all citizens.

In many ways, the dimensions and challenges of prisoner reentry observed on the national level are mirrored in the state of Texas. The Texas Department of Criminal Justice (TDCJ) is the state agency responsible for individuals incarcerated in state prisons, state jails, and private prisons. This agency also supervises individuals on parole and mandatory supervision 
through the TDCJ Parole Division and oversees adult probation (community supervision) through the TDCJ Community Justice Assistance Division. In 2001, 55,183 people were released from TDCJ correctional facilities - more than five times the number released two decades ago $(10,636$ in 1980). ${ }^{7}$

Nearly all (99 percent) of the men and women released from Texas facilities returned to neighborhoods in Texas. ${ }^{8}$ Of those prisoners who returned to Texas, 59 percent returned to 5 of 254 counties in Texas. Approximately a quarter (26 percent) returned to Harris County, 15 percent resumed residence in Dallas County, about 8 percent returned to Tarrant County, 6 percent went home to Bexar County, and 4 percent returned to Travis County.

With the largest share of ex-prisoners returning to Harris County, this report gives special attention to Houston, the largest metropolitan city in Harris County, using the data set provided by TDCJ. Of the prisoners released to supervision who returned to Harris County, 88 percent established residence in Houston. Within Houston, the flow of these prisoners was further concentrated in a small number of neighborhoods. A quarter of the 5,823 supervised releasees who returned to Houston returned to 5 of the city's 185 zip codes: 77072, the vast majority of which is encompassed by the neighborhood of Alief; 77078, most of which is included in the neighborhood of East Houston, where a halfway house is located; 77004, which spans the neighborhoods of Greater Third Ward and MacGregor; 77026, most of which spans the neighborhoods of Kashmere Gardens and Trinity/Houston Gardens; and 77016, which is mostly encompassed by the neighborhoods of East Little York/Homestead and Trinity/Houston Gardens. These neighborhoods, which already face great social and economic disadvantages, may experience the challenges of reentry more acutely.

Government leaders, corrections officials, local organizations, and service providers are keenly aware of the reentry challenges in Texas, and they have begun to use both research and programmatic knowledge to address them. In July 2002, the Texas Department of Criminal

\section{REENTRY DEFINED}

For the purposes of this report, "reentry" is defined as the process of individuals leaving adult correctional institutions and returning to society. We have limited our scope to those sentenced to serve time in state correctional institutions to focus on individuals who are convicted of more serious offenses, are eligible for state correctional programs, and are managed by state correctional, parole, and felony probation systems. Texas holds two categories of felons in state correctional facilities. The first category is referred to as "state prisoner" and the second category is referred to as "confinee." (See the sidebar "State Jail Confinees" on page xvi for a discussion of the history of confinees and differences between state prisoners and confinees.) In spite of differences between these populations, illustration of a more complete picture of reentry in Texas requires a discussion of both populations since they are both under state custody and confinees now represent a third of all TDCJ releases. While the two populations may require different reentry programs and policies, the vast majority of both populations returns to the community following state custody and are therefore both components of the reentry phenomenon in Texas. A comprehensive depiction of reentry in Texas, describing prisoners released from county jails, state prisons, federal institutions, and juvenile facilities returning to the state, is beyond the scope of this report. This report is intended to inform the policy and practice for those persons under adult state custody. 
Justice was awarded \$2 million from the U.S. Department of Justice, Office of Justice Programs, as part of the federal government's Serious and Violent Offender Reentry Initiative, which supports reentry initiatives nationwide. This recent grant provides the opportunity for Texas to continue to expand upon current reentry initiatives in the state. Specifically, a share of the funds will be used to develop reentry programs for administrative segregation prisoners, who currently have access to few or no programs, from three counties (Bexar, Dallas, and Harris). ${ }^{9}$ Texas also has a well-established reentry program, Project RIO (Reintegration of Offenders), which launched in 1985. Project RIO assists approximately 70,000 prisoners each year, before and after their release, in finding and securing employment. ${ }^{10}$ Several other reentry initiatives have been established in Harris County in recent years, such as Barriers to Employment, Girl Scouts Behind Bars, and the InnerChange Freedom Initiative. For example, the Joe Kegans State Jail (located in Houston) and the United Way's Career and Recovery Resources agency began Barriers to Employment, an in-prison program that prepares state jail felons to secure employment following release. ${ }^{11}$ These collaborative efforts are positive steps toward improving reentry outcomes in Texas and, specifically, in Houston, the city housing the greatest share of returning prisoners.

This report is designed to contribute to the efforts under way in Texas to enhance public safety and improve the prospects for successful state prisoner reintegration. It is important to note that this report does not attempt to evaluate a specific reentry program, nor does it empirically assess Texas's reentry policies and practices. Rather, the process and characteristics of state prisoner reentry in Texas are described by answering several questions that frame the organization of the report:

- What is the policy context surrounding state prisoner reentry in Texas?

- Who is returning home?

- How are Texas prisoners prepared for reentry?

- How are Texas prisoners released?

- How are Texas prisoners supervised upon release?

- Where are Texas prisoners going?

- To which Houston neighborhoods are prisoners returning?

The report begins by describing the policy context surrounding incarceration and reentry in Texas, followed by a description of the characteristics of prisoners released from Texas in 2001 and the ways in which Texas prisoners are prepared for release. Next we provide an overview of the institutional release process and of postrelease supervision trends and processes. We then turn our attention to an analysis of reentry in select Texas counties, and then further focus on Houston, to which the largest number and percentage of Texas releasees return. We describe and discuss the characteristics of Houston and the unique challenges the city faces because of the reintegration of prisoners. The report concludes with a spatial analysis of select neighborhoods in Houston to which a large percentage of prisoners return. It is our hope that this report will provide 
a useful, factual foundation for the individuals and organizations working to improve reentry outcomes for state prisoners, their families and neighborhoods, and the general public in Texas.

\section{STATE JAIL CONFINEES}

In 1993, the Texas legislature revised the state's criminal law code and established a new felony offense class, state jail felonies. ${ }^{12}$ The legislature shifted low-level drug and property offenders (nonviolent Class A misdemeanors and third-degree felons) into this category primarily to reduce overcrowding in state prisons, the cost of incarceration, and recidivism. This law took effect on September 1, 1994. The majority (78 percent) of offenders convicted of a state jail felony offense are sentenced to a term of probation, but most of the remaining offenders are sentenced to a period of incarceration in one of Texas's 17 state jails. Texas criminal justice officials refer to those prisoners confined in state jails as "confinees" and are referenced as such in this report.

Confinees are sentenced to state jails for new state jail felony offenses (direct sentence), up-front time (incarceration prior to release to probation), or probation revocation; they are not sentenced to these facilities for parole or mandatory supervision revocation. Unlike state prisoners who generally cannot receive sentences of less than two years, confinees cannot receive sentences longer than two years. For all other sentences besides probation revocation (which requires that a confinee serve the remainder of his sentence), confinees cannot receive a sentence of less than 75 days. While most state prisoners are released early through parole or credits for good behavior, virtually all confinees serve every day of their sentences since none are eligible for these early release mechanisms. In turn, 97 percent of state jail offenders are not supervised upon release while 84 percent of state prisoners are. Confinees, however, are obligated to participate in six hours of community service or educational, vocational, or substance abuse programs each day.

In addition to confinees, state jails house for up to two years nonviolent state prisoners awaiting relocation to a state prison. As of July 31, 1998, confinees accounted for slightly more than a third (38 percent) of those held in Texas's state jails; transfer prisoners accounted for the remaining two-thirds (62 percent). 


\section{ABOUT THE DATA}

The data used for this report were derived from several sources. Longitudinal data describing the policy context of incarceration and reentry trends in Texas were derived from the U.S. Department of Justice's Bureau of Justice Statistics and statistics compiled by various agencies within the state of Texas, such as the Criminal Justice Policy Council (CJPC) and the Texas Department of Criminal Justice. Community-level data used to develop the maps of reentry, as well as related demographic and socioeconomic status data by Houston neighborhood, were derived from census data compiled by the city of Houston, available from their website, http://ci.houston.tx.us/. The City of Houston also provided the crime rate data and the files that enabled us to aggregate and map data according to the 88 Houston community areas. Elycia Daniel, a Ph.D. candidate at Sam Houston State University, collected the offender services data for Houston.

The available data from each of these sources spanned different periods-some had data for only a few years, while others had data for two decades or longer. Rather than truncating longitudinal data so that graphs and statistics from all sources cover a common time span, we chose to include all years for which we were able to obtain data points. As a result, readers will not always be able to make year-to-year comparisons across graphs. Much of our consecutive longitudinal data begins in fiscal year 1988, the first year of data that the CJPC was able to review and clean to ensure its reliability, and stops at fiscal year 2002. In some cases, we were able to obtain a single data point for a more recent year. In these instances, because of the gaps between data points, readers may see statistics presented in the text that are not included in the figures.

Data on the population of prisoners released from Texas prisons and state jails in calendar year 2001 were obtained from TDCJ and represent only those prisoners released to the community from TDCJ custody. Prisoners who received sentences of less than one year are included in the sample. These short-term prisoners face different reentry challenges since they are housed for relatively short periods of time, are ineligible for some programs, and are not subject to postrelease supervision. However, confinees make up a growing proportion of the state prisoner release population (36 percent in 2002) and, therefore, are included in this report.

The 2001 cohort data from TDCJ include the state, county, and zip code to which prisoners returned. These data were used to analyze the geographic location of prisoners following their release. The state and county to which prisoners returned was available for 65 percent of all prisoners in the data set; the state and county of release for the remaining 34 percent of prisoners were approximated by using the state and county of conviction. These data were available for all but 1 percent of prisoners. Zip codes were used for an analysis of the prisoners returning to the five counties receiving the greatest share of ex-prisoners. Zip codes were only available for prisoners released to parole or mandatory supervision (42 percent of all prisoners). We compared both groups (those with and those without zip code information available) across a host of demographic and criminal justice characteristics. A chisquare test revealed statistically significant differences across all variables (see the summary of the characteristics of these populations in appendix A). Thus, readers should refrain from generalizing the characteristics of supervised releasees to those of non-supervised releases (see the summary of the characteristics of these populations in appendix $A$ ). 


\section{ABOUT THE DATA (CONTINUED)}

It should also be noted that because zip codes can span neighborhoods and counties, the maps showing the location of released prisoners to Houston neighborhoods by zip codes are approximate. The same is true for the Houston crime rate by community data. Because the crime data were available by police beat rather than by community, the police beats were aggregated to the community level. As with zip codes, police beats can span multiple communities and thus the crime rate distributions are approximations.

The Criminal Justice Policy Council's reports and statistical tables are the basis of most of the longitudinal data describing trends for TDCJ prisoners. The reported TDCJ admissions underestimate the actual number of state prisoners admitted to correctional custody. These data do not include state prisoners who are never admitted to TDCJ facilities; the data therefore miss state prisoners who complete their sentences in county jails, out-of-state jails or prisons, or federal prisons. The undercount is noteworthy. Most of the uncounted prisoners are housed in county jails. Thousands of state prisoners have been and are held in county jails at any given time $(5,778$ convicted felons were held in the county jails in fiscal year 2002). But the largest overflow to the county jails occurred between 1990 and 1994, during which time TDCJ held up to 26,000 state prisoners in county jails; the data during these years are thus expected to undercount admissions and releases to the greatest extent. Likewise, during these years, around 10,000 prisoners were paroled from facilities not administered by TDCJ each year under "parole in absentia."

We address these challenges in several ways. To capture the true standing prison population totals, we add those TDCJ prisoners held in county jails to the standing TDCJ prison population counts. The prison population counts therefore only miss those Texas felons not held in either TDCJ facilities or county jails in Texas, such as out-of-state prisons, but the total number of missed prisoners is expected to be low. Thus, the prison population estimates should be generally accurate.

Producing an accurate estimation of admissions trends is more difficult given that the annual admissions of state prisoners to non-TDCJ facilities are unavailable. However, to show an estimation of the maximum number of admissions possible, we illustrate the total number of sentences to state prison in addition to the total number of TDCJ admissions. Sentences to state jail are not available, but because these facilities have not been overcrowded, the total number of admissions to state jails should approximate the total number of newly sentenced state jail felons admitted to correctional facilities. To compare trends for admissions and releases, we report releases from TDCJ facilities only. 


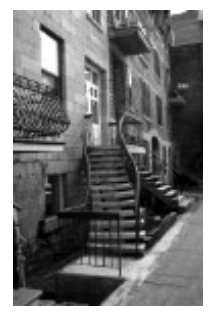

\section{H A P T E R 1}

\section{What Is the Policy Context Surrounding Prisoner Reentry in Texas?}

$\mathrm{T}$ o fully understand prisoner reentry in Texas, it is first necessary to examine the state's trends in sentencing, corrections, and release. This chapter provides an overview of these trends and describes the factors that contributed to the rapid growth in Texas's prison population.

\section{TEXAS PRISON POPULATION ON THE RISE}

Over the past two decades, the Texas prison population grew tremendously, reflecting the rise in prison populations nationwide. ${ }^{13}$ From 1980 to 2002, the Texas prison population increased more than fivefold, from 28,543 to 151,003 (figure 1.1). ${ }^{14}$ During this time, the Texas incarceration rate grew 248 percent (from 199 to 693 prisoners per 100,000 residents) while the U.S. incarceration rate grew 242 percent (from 139 to 476 prisoners per 100,000 residents) (figure 1.2). ${ }^{15}$ By the end of 2002, Texas held the second-largest state prison population in the nation and had the thirdhighest state incarceration rate. ${ }^{16}$

Figure 1.1. TDCJ prison population, FY 1980 to FY 2002

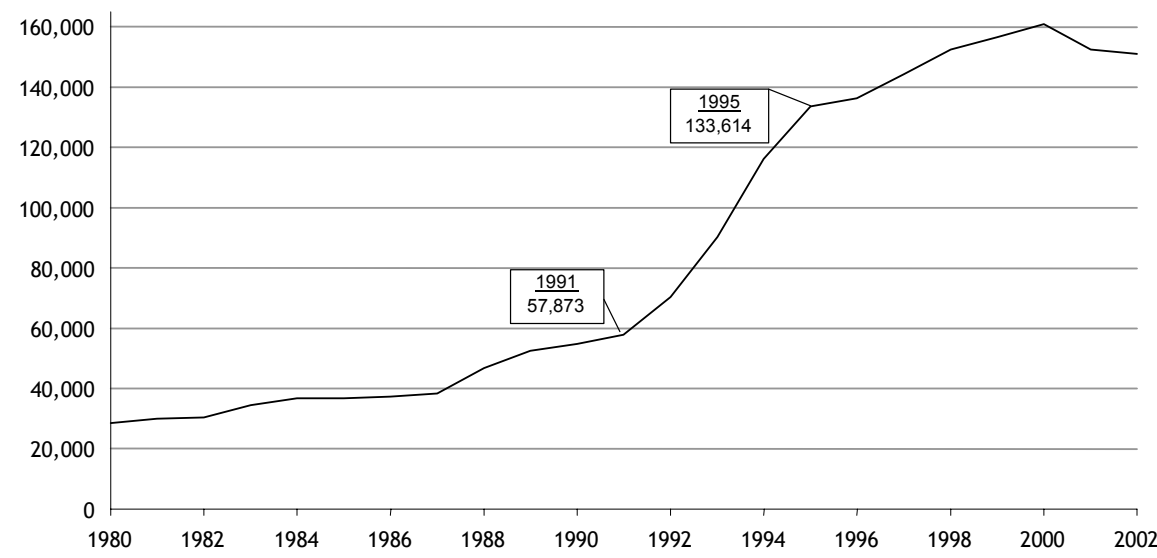

Source: Urban Institute analysis of TDCJ, Criminal Justice Policy Council, and U.S. Bureau of Justice Statistics. 
Figure 1.2. Texas and U.S. incarceration rates (per 100,000 residents), FY 1980 to FY 2002

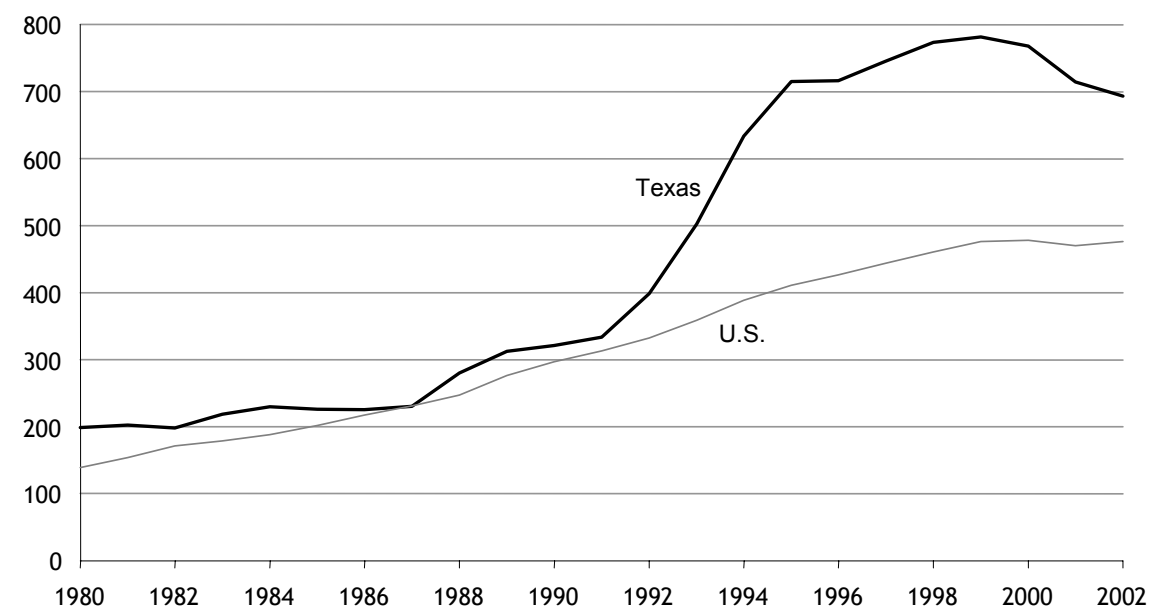

Source: Urban Institute analysis of TDCJ, Criminal Justice Policy Council, U.S. Bureau of Justice Statistics, and U.S. Census Bureau data.

Figure 1.3. TDCJ capacity (number of beds), FY 1980 to FY 1997

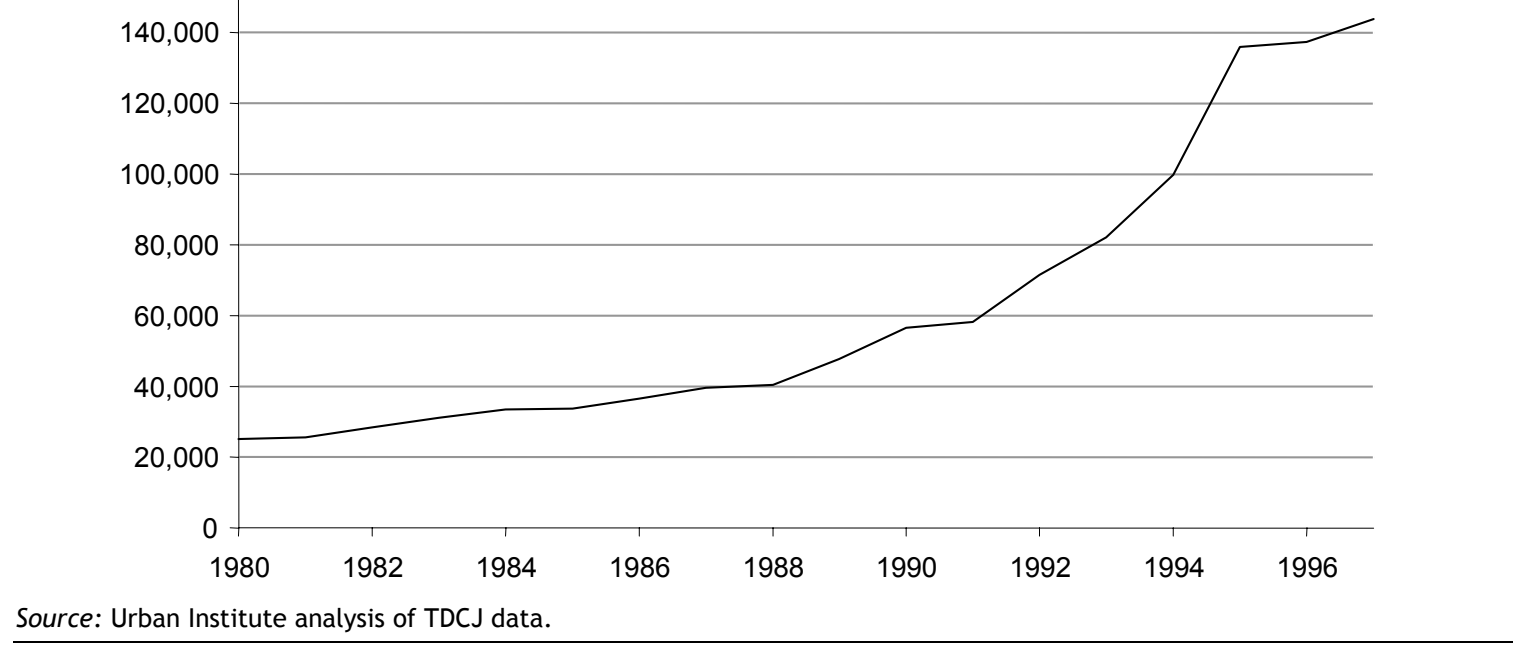

The number of state correctional facilities doubled in the 1980 s, from 17 to 35 , and tripled in the 1990s, from 35 to $105 .{ }^{17}$ Likewise, between 1980 and 1997, the number of beds available to house Texas prisoners increased by 473 percent, from 25,129 to 143,908 (figure 1.3). ${ }^{18}$ The legislature appropriated nearly $\$ 2.3$ billion between 1988 and 1997 to construct 108,597 beds. $^{19}$

Overall spending on state corrections has also increased during this time. Between 1990 and 2000, total appropriations for TDCJ increased by 31 percent, rising from $\$ 1.8$ billion in 1990 (adjusted for inflation) to $\$ 2.4$ billion in $2000 .{ }^{20}$ In fiscal year 1999 , Texas spent $\$ 179$ per capita on corrections, slightly higher than the national average of $\$ 162$ and representing the 12th-highest per capita corrections expenditures in the nation. ${ }^{21}$ However, given the large number of prisoners 
incarcerated in Texas, these costs average approximately $\$ 40$ per prisoner per day, which is significantly lower than the national average of $\$ 54 .^{22}$

\section{EXAMINATION OF TEXAS'S INCARCERATION GROWTH}

Although the Texas prison population has grown throughout the past three decades, it grew most dramatically from 1991 to 1995 . In these years, the state prison population grew by nearly 120 percent (from 57,873 to 127,559), and the incarceration rate grew by 114 percent, from 334 to 715 prisoners per 100,000 residents (figures 1.1 and 1.2). This section examines potential causes underlying these trends, devoting special attention to these years.

A state's prison population may grow if admissions to prison increase and/or prisoners spend more time in prison. Increases in both of these factors-prison admissions and the time spent in prison (time served) - contributed to the growth in Texas's prison population. Between 1988 and 2002, TDCJ admissions grew 78 percent, from 33,816 to 60,196 prisoners per year (figure 1.4). Likewise, released prisoners' time served grew 83 percent, from 1.8 to 3.3 years on average (figure 1.5). As the following discussion will show, admissions increased during this time primarily due to a rising number of arrests for violent and drug crimes and an increase in felony convictions. Notably, crime fell during most of this period of time in spite of growth in the number of Texas adult residents. Time served increased mainly because most prisoners were serving longer sentences and prisoners were also serving longer portions of their sentences. Prisoners served greater portions of their sentences due to falling parole approval rates and legislation that required prisoners serve longer portions of their sentences.

Figure 1.4. TDCJ admissions, TDCJ releases, and sentences to prison, FY 1980 to FY 2002

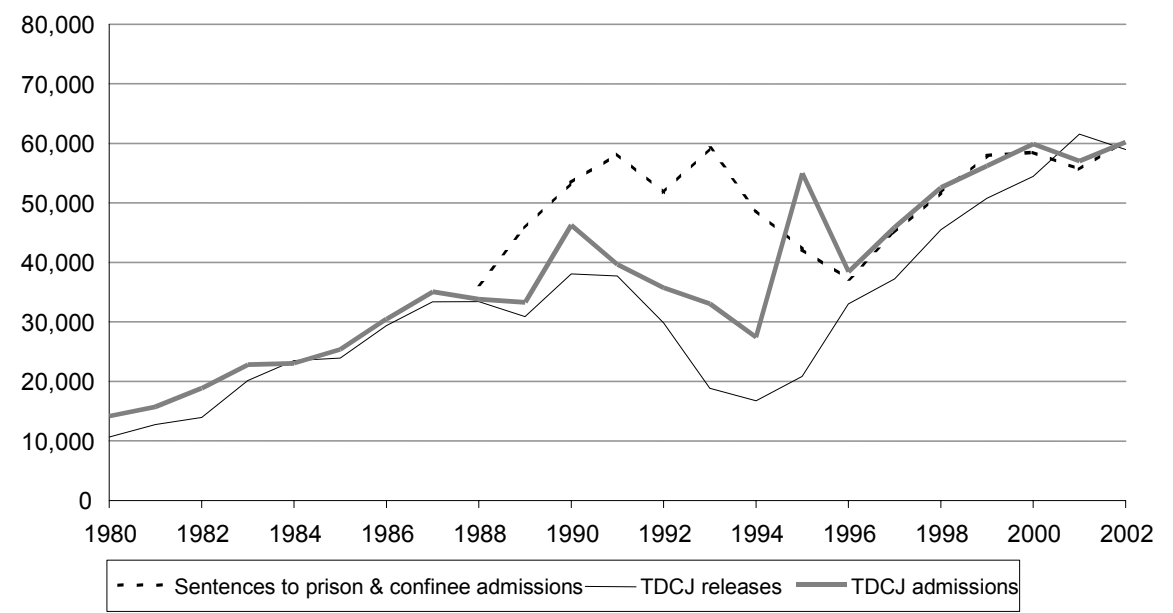

Note: None of the admissions or release data include TDCJ prisoners who were admitted to county jails and completed their sentence there.

Source: Urban Institute analysis of TDCJ and Criminal Justice Policy Council data. 
Figure 1.5. Time served by Texas releases (in years), FY 1988 to FY 2002

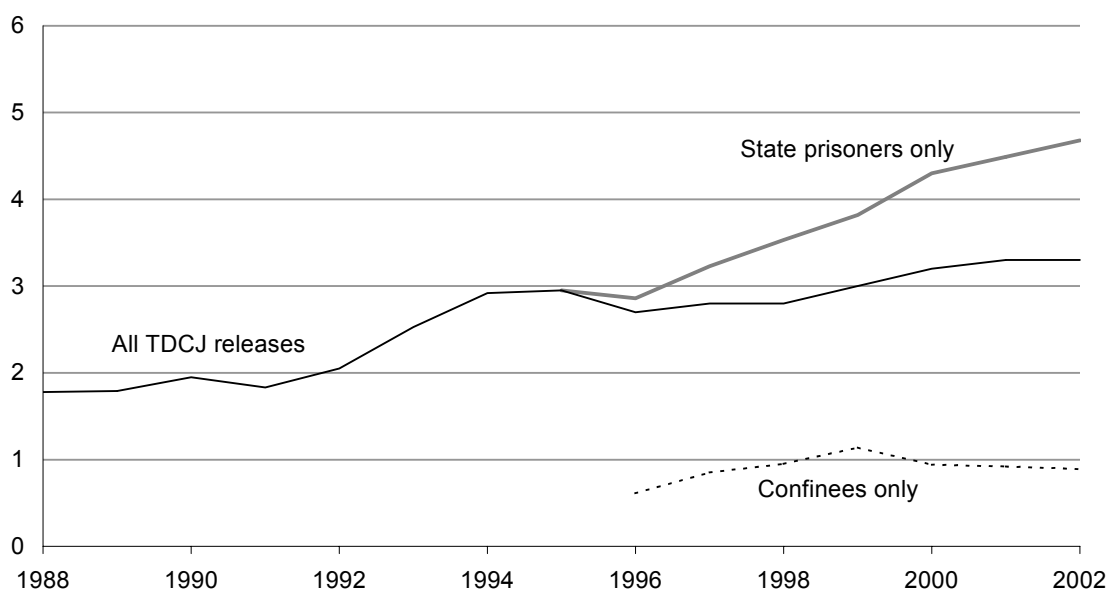

Source: Urban Institute analysis of Criminal Justice Policy Council data.

Before proceeding to a more in-depth discussion of these trends, an explanation of the peaks and valleys that characterized TDCJ admissions and releases between 1990 and 1995 is warranted (figure 1.4). ${ }^{23}$ These fluctuations reflect the fact that the admissions and release totals only reflect admissions and releases to TDCJ facilities, and during this time many felons were admitted and released from non-TDCJ facilities (e.g., county jails) due to overcrowding in TDCJ facilities. Between 1988 and 1990, admissions approximated the total number of sentences to prison. Then, from 1991 to 1994, many TDCJ prisoners were admitted to county jails rather than to TDCJ facilities to manage overcrowding. ${ }^{24}$ Consequently, sentences to prison far exceeded admissions during this time. The overflow to county jails peaked in 1993 at close to 26,000 state prisoners (figure 1.6). Admissions grew dramatically in 1995 with the opening of 36,000 TDCJ beds. Consequently, admissions closely approximated sentences to prison after this year. During this time, release trends tended to follow admission trends.

Figure 1.6. Convicted felons in county jails awaiting transfer to TDCJ, FY 1988 to FY 2002

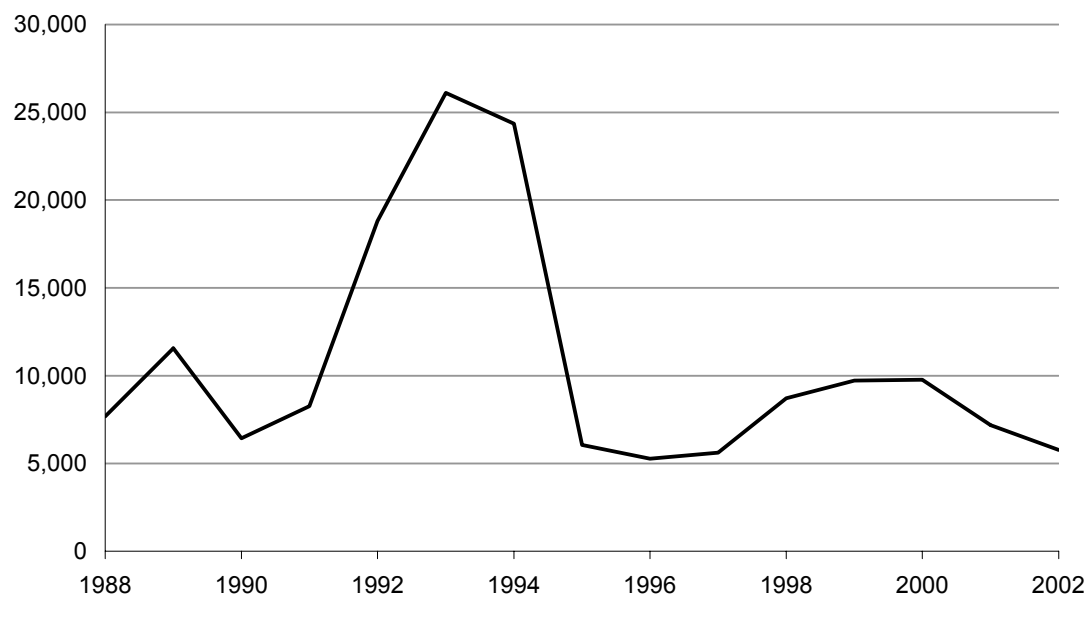

Source: Urban Institute analysis of Criminal Justice Criminal Justice Policy Council. 


\section{Increased Admissions}

Increases in crime rates and, in particular, violent crime rates across the United States in the latter part of the 20th century heightened concerns about public safety and coincided with a shift in the political landscape. American sentencing policy generally became more punitive, policing practices more stringent, and revocations of parole and probation more common. The convergence of these forces together often resulted in increased admissions to prison. This section reviews the role that each of these factors played in Texas admissions from 1988 to 2002.

\section{Crime Trends}

An increase in the number of crimes can lead to an increase in arrests, convictions, and ultimately, to an increase in prison admissions. ${ }^{25}$ In Texas, however, crime does not appear to have contributed to the increase in prison admissions.

Crime in Texas was stable between 1988 and 1991 (figure 1.7). Crime then fell until 2000 when it began to rise slightly. Total crimes fell throughout the 1990s - even while adult residents in Texas increased in number (by 23 percent). ${ }^{26}$ Taking Texas's population growth into account, we find that Texas's crime rate (reported crimes per 100,000 residents) had begun to generally decline in 1988 and continued to fall until 2000.

These numbers portray overall crime trends, however, and include many crimes that do not typically result in prison sentences. Therefore, overall crime could decrease while the prison population could increase as a result of an increase in serious crimes, which are more likely to result in prison sentences. Violent (serious) crime rose between 1988 and $1991 .^{27}$ In 1988, violent crimes approached 110,000; by 1991, violent crime slightly exceeded 140,000 (figure 1.8). Violent crime then fell and continued to fall until beginning to slightly increase after 1998. In 2001, violent crimes totaled approximately 120,000. Between 1988 and 1991, property crime remained stable; it then fell until 2000, when it began to rise again (figure 1.9) ${ }^{28}$ In 2001,

Figure 1.7. Total number of all reported crimes in Texas, FY 1988 to FY 2001

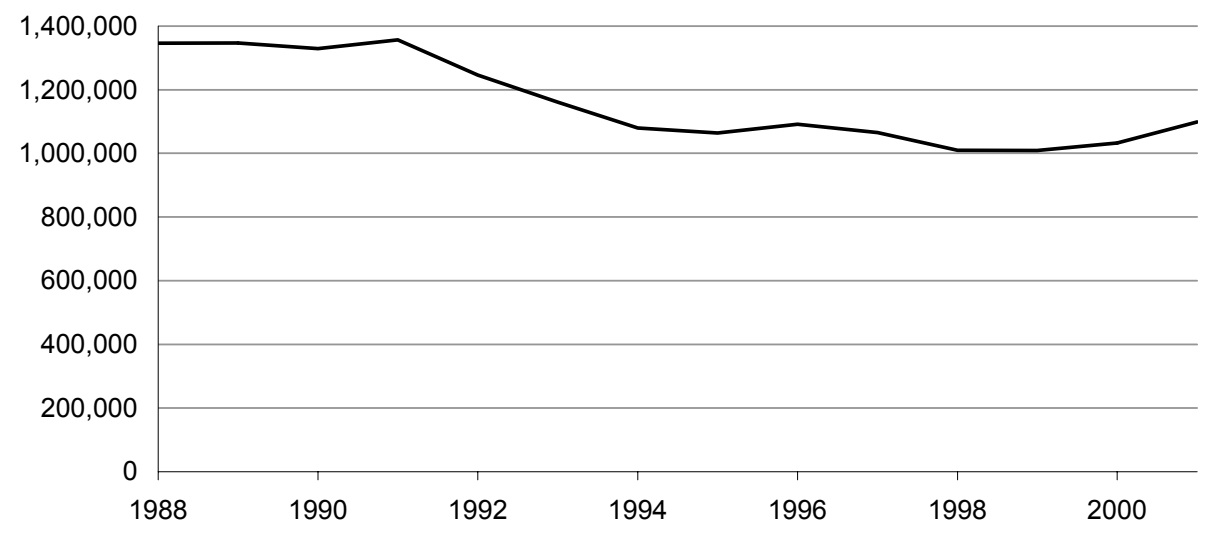

Source: Urban Institute analysis of Criminal Justice Policy Council data. 
Figure 1.8. Total number of reported violent crimes in Texas, FY 1988 to FY 2001

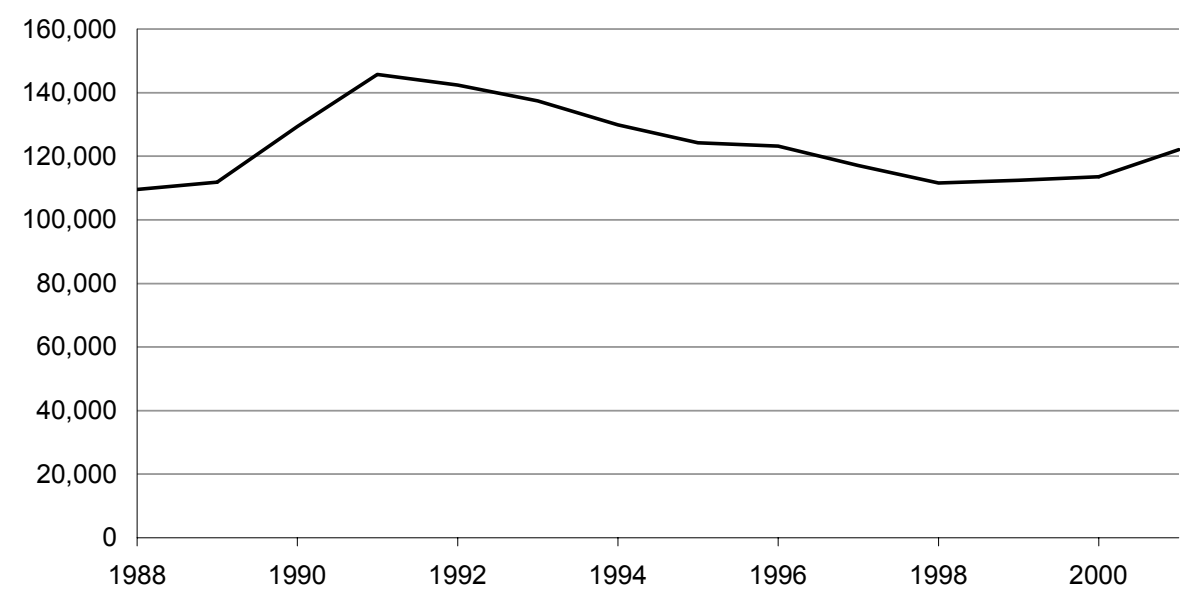

Source: Urban Institute analysis of Criminal Justice Policy Council data.

Figure 1.9. Total number of reported property crimes in Texas, FY 1988 to FY 2001

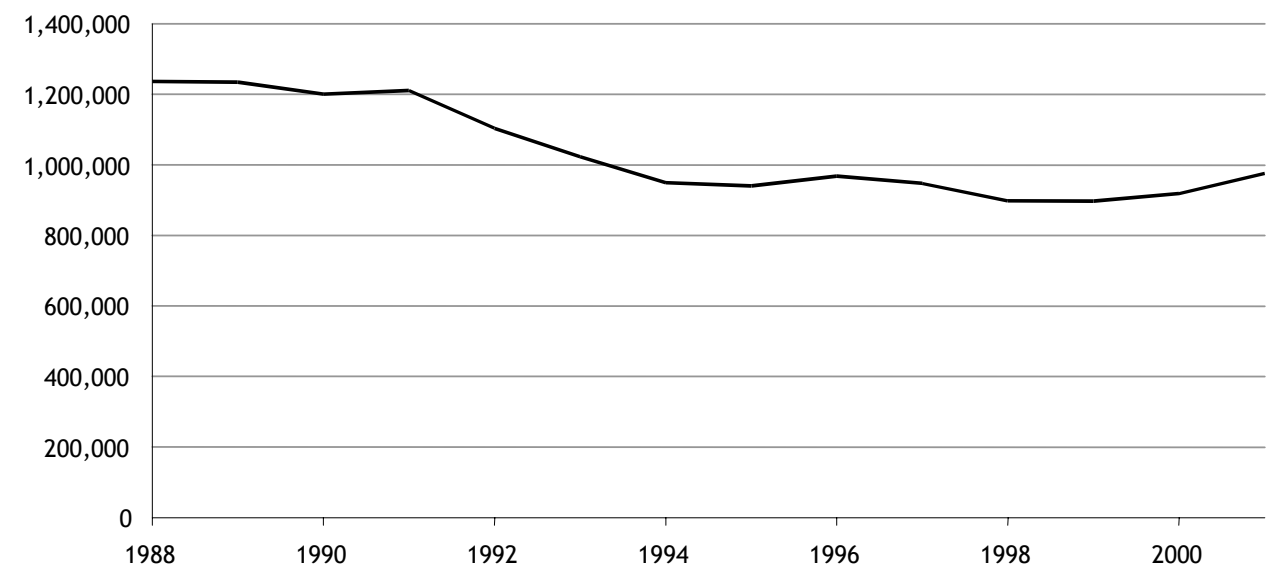

Source: Urban Institute analysis of Criminal Justice Policy Council data.

property crimes totaled less than 1 million. Thus, the most serious offenses (violent), along with less serious offenses (property), were both falling during the period when Texas's incarceration rate was growing most significantly. An analysis of these trends for drug crimes cannot be included in this discussion since police departments in Texas and throughout the United States do not record reported drug crimes due to the fact that they rarely involve a victim.

\section{Arrest and Conviction Trends}

Regardless of trends for incidence in crime, admissions to prison may increase if police departments are making more arrests and those arrested receive prison sentences. A marked rise in arrests for drug and violent crimes, along with an increase in felony convictions, likely contributed significantly to Texas's growing admissions. 
Figure 1.10. Adult (age 17 and older) arrests in Texas by select offense types, FY 1988 to FY 2001

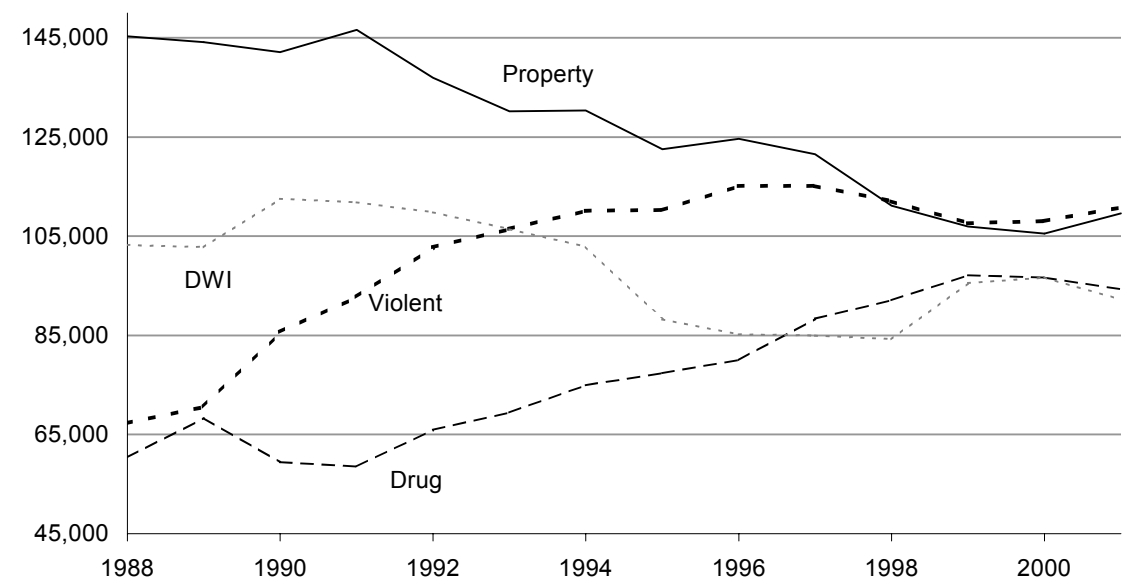

Source: Urban Institute analysis of Texas Department of Public Safety.

In Texas, adult arrests grew by 25 percent (from 752,698 to 942,481) between 1988 and $1994 .{ }^{29}$ Since that time, adult arrests remained generally stable, although they fell slightly—by 5 percent to 891,437 - in 2001. Rising adult arrests may well have contributed to Texas's incarceration growth through 1994. Disaggregating arrests by offense type helps to clarify the impact of arrests on prison admissions. Therefore, we also examine trends for violent, property, driving-while-intoxicated (DWI), and drug offenses separately. ${ }^{30}$

Figure 1.10 shows that, between 1988 and 2001, violent crime arrests rose (from 67,275 to 110,840 ) - even after 1992 when reported violent crimes fell. ${ }^{31}$ The influence of these factors on the prison population is unclear, however. While violent crime fell, arrests for violent offenses grew until 1996 and then they largely stabilized. Violent offenders rose as a share of the admissions population until 1994, when they began to fall as a share (figure 1.11). Arrests for drug offenses also rose in this period, and drug offenders accounted for a growing share of the admissions population. ${ }^{32}$ Mirroring property crime trends, arrests for property crimes generally fell in this period. ${ }^{33}$ Likewise, property offenders' share of admissions tended to shrink during this time.

In 1987, Texas created 45 regional narcotics task forces (RNTFs), primarily to decrease drug crimes in rural areas, but they have operated in urban areas as well. ${ }^{34}$ These decentralized task forces may have contributed to the increase in drug arrests since a key measure of these units' success is the number of drug arrests they make. ${ }^{35}$ From fiscal years 1997 to 2003 (the years for which data were available), the RNTFs arrested between 12,000 and 19,500 individuals annually, accounting for a significant share (10 to 21 percent) of all drug crime arrests during these years.

Increased arrests only contribute to an increase in the prison population if the arrests lead to felony convictions and sentences to prison or state jail. In Texas, the total number of felony 
Figure 1.11. TDCJ admissions by offense type as a percentage of all admissions, FY 1988 to FY 2002

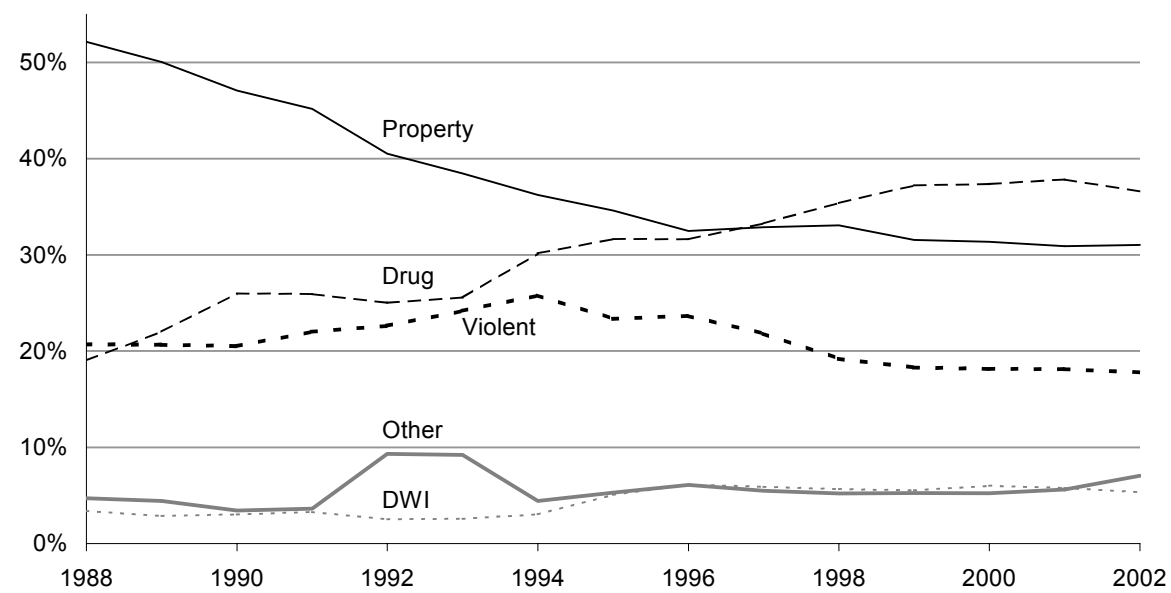

Source: Urban Institute analysis of Criminal Justice Policy Council data.

convictions rose from 73,049 in 1988 to 89,245 in 1991. They then fell until 1996, when they totaled 74,882. The number of convictions then rose again, reaching 90,669 in 2002. Notably, during this time, conviction rates had actually fallen. Between 1988 and 1994, conviction rates fell from 80 to 70 percent and then stabilized. ${ }^{36}$ A rise in arrests likely contributed to the growth in the prison population in the first half of the 1990s while rising felony convictions contributed to the growth in the second half.

\section{Parole and Probation Revocation}

Another potential cause of increased admissions is an increase in parole and probation revocations. In Texas, however, revocations contributed minimally to the increase in TDCJ admissions during this time. ${ }^{37}$ A parole or probation revocation may be the result of the commission of a new crime or a technical violation of a condition of supervision (such as the requirement to report to the supervising officer). Revocations accounted for a significant but stable share of all TDCJ admissions from 1988 to 2002, only rising slightly (by 4 percent) between 1991 and 1994 (figure 1.12). 
Figure 1.12. Revocations as a share of TDCJ admissions, FY 1988 to FY 2002

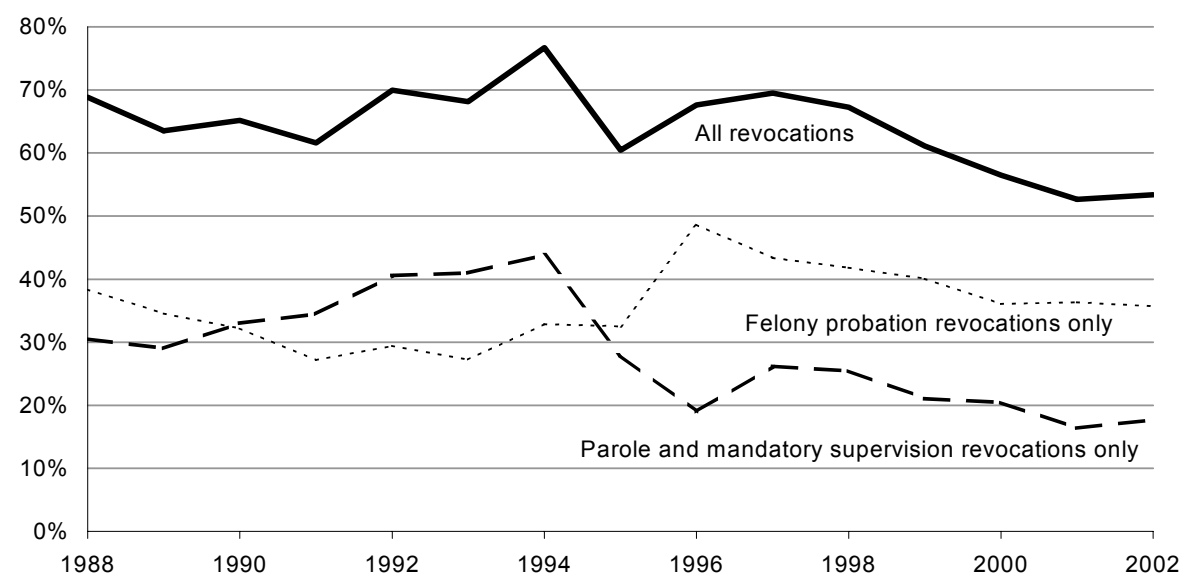

Source: Urban Institute analysis of Criminal Justice Policy Council data.

\section{Increased Lengths of Stay}

The main cause of Texas's incarceration growth is the rising length of prisoners' stays in TDCJ facilities, or the actual time served in these facilities. ${ }^{38}$ Time served for Texas prisoners has increased fairly consistently in the past 14 years (refer back to figure 1.5). Prisoners released in 1988 served an average of 1.8 years; by 2002, they served an average of 3.3 years - an increase of 83 percent. The most marked increase in time served occurred between 1992 and 1995, which coincided with the largest increase in the TDCJ prison population (from 51,592 to 127,559). Comparing Texas's experience with national trends, Texas prisoners' time served grew 57 percent between 1990 and 2000, outpacing the 32 percent growth in time served by state and federal prisoners across the nation during that time. ${ }^{39}$ In 1990, Texas prisoners served 1.9 years on average, approximating the time served by state prisoners throughout the nation (1.8 years). But by 2000, Texas prisoners were spending 37 percent more time incarcerated than the average state prisoner nationwide (3.2 years versus 2.3 years). This section reviews the impacts of sentence length, percentage of sentence served, parole, and good-behavior credits on Texas prisoners' lengths of stay from 1988 to 2002.

\section{Sentence Length}

Increases in the length of sentences can cause prison populations to grow by increasing the time state prisoners are incarcerated. ${ }^{40}$ In Texas, the sentence length for most state prisoners increased during much of the past decade and therefore may have contributed to the increase in time served.

For Texas prisoners released between 1988 and 1994, the length of sentence grew substantially - by 46 percent - from 7.7 to 11.2 years (figure 1.13). This increase in sentence length applied to all prisoner types: nonviolent offenders' sentences grew the most-by 60 percent (from 6.8 to 10.9 years); aggravated crime offenders' sentences grew by 34 percent (from 
10.7 to 14.3 years); and violent crime offenders' sentences grew by 12 percent (from 11.3 to 12.6 years). ${ }^{41}$ Between 1994 and 1998, the average sentence length dropped dramatically from 11.2 to 6.1 years, and from 1998 to 2002 it remained relatively stable. ${ }^{42}$

The state jail felon category took effect in fiscal year 1995 (this population will be discussed further throughout the text; also see "State Jail Confinees" sidebar in the introduction for further explanation). This legislation lowered the maximum sentence length for nonviolent Class A misdemeanors and third-degree felons from 25 years to 2 years; prison administrators in Texas refer to these prisoners as confinees. Prior to this time, all prisoners' sentences were a minimum of 2 years; after this time, confinees (the new category of felons) could receive sentences of as little as 75 days for a new crime and no more than 2 years for any offense.

Figure 1.13. Sentence length (in years) of all TDCJ releases, FY 1988 to FY 2002

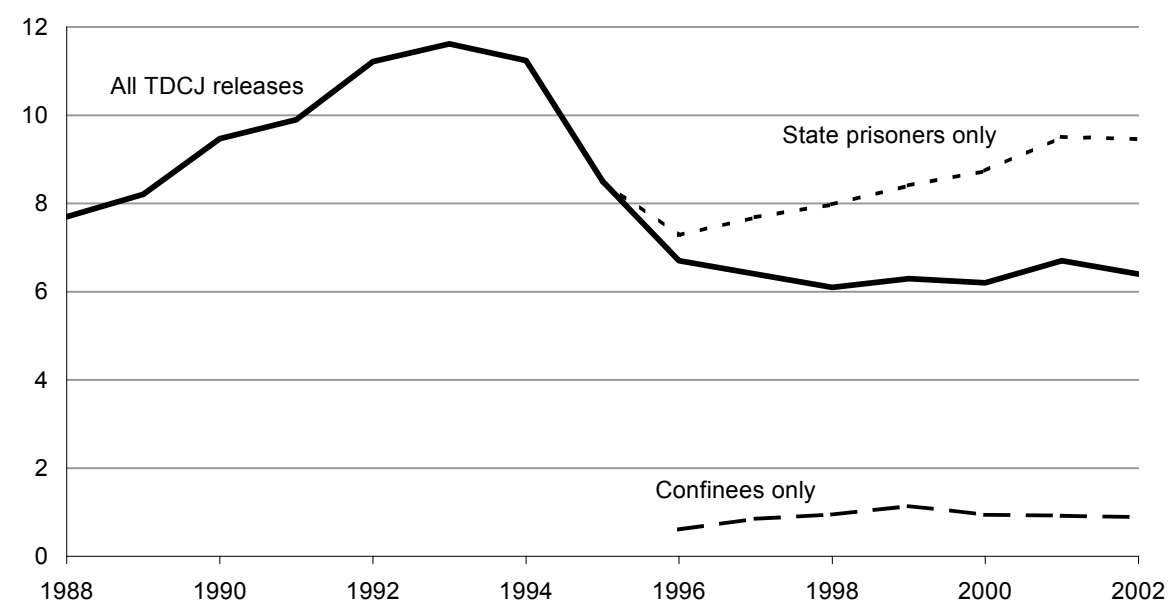

Source: Urban Institute analysis of Criminal Justice Policy Council data.

Between 1996 (the year that data are first available) and 2002, confinees received, on average, 11-month sentences. Alternatively, state prisoners' sentences grew longer during this time, from 7.3 to 9.5 years, since the less serious offenders with shorter sentences removed from the state prison population. Since state prisoners make up the majority (two-thirds) of all released prisoners, most prisoners' sentence lengths increased during this time.

Rising sentence lengths, however, may not translate into increased time served (time spent incarcerated) if prisoners are, for example, being released early to parole. For confinees, sentence length directly impacts time served since they are ineligible for parole and mandatory supervision (and thus early release). ${ }^{43}$ All but the two percent of confinees who are released to shock probation serve their full term. ${ }^{44}$ Although state prisoners are eligible for parole and mandatory supervision, the changes in their sentence lengths likely affected their time served. For example, as the average sentence length for state prisoners grew by 23 percent from 1988 to 2002 (from 7.7 years to 9.5 years), the average time served grew by 85 percent (from 1.8 to 3.3 years). (Please refer back to figure 1.5.) Clearly, changes in sentence length cannot explain the total 
increase in time served. We will now examine other factors that may have affected state prisoners' time served.

\section{Percentage of Sentence Served}

Policies and practices for both parole and good-conduct time can affect the percentage of a sentence that a prisoner serves (discussed below). In addition, in the past decade, a number of states across the nation, including Texas, have passed legislation requiring state prisoners to serve longer portions of their sentences. ${ }^{45}$ By making confinees ineligible for parole or mandatory supervision, the Texas legislature ensured that nearly all of these prisoners would serve 100 percent of their sentences. However, Texas still requires state prisoners (the majority of prisoners) to serve at least 25 to 50 percent of their sentences - substantially less than the 85 percent minimum requirement of nearly all other states. ${ }^{46}$

In 1987, new legislation required that Texas prisoners' time served and credits for good behavior sum to at least 25 percent of their sentences before they were eligible for parole or release to mandatory supervision. ${ }^{47}$ Since then, the legislature has increased the percentage to 33 percent, or to 50 percent for some state prisoners who committed serious violent and aggravated offenses; the most significant legislative increases in the percentage of time served occurred in 1987 and 1993. Although Texas increased this percentage requirement for some prisoners, Texas remains only one of three states that allow prisoners to become eligible for parole after serving, with good-time credits, less than 85 percent of their sentences - the percentage recommended by the federal government. ${ }^{48}$ Confinees are subject to distinct requirements. Since their creation in 1993, confinees have been ineligible for parole or good-time credits (i.e., release to mandatory supervision), and all but 2 percent, who are released at a judge's discretion through shock probation, serve 100 percent of their sentences.

Trends in the percentage of the sentence that prisoners are serving reflect these legislative changes (figure 1.14). ${ }^{49}$ State prisoners released in 1993 served 27 percent of their sentences; by 2002 , they were serving 58 percent. The percentage of sentence served approximately doubled for all offender types, including nonviolent offenders. ${ }^{50}$ Today, more releasees are also serving 100 percent of their sentences (i.e., were "discharged"), receiving no early release through parole, good-behavior credits, or shock probation. In 1988, less than 1 percent of all prisoners were discharged; by 2002, 45 percent were. Although the proportion of discharged state prisoners has increased, the primary reason for the marked rise in discharges is due to the growth in the number of confinee releases. In 1988, the confinee category did not exist; by 2002, confinees constituted 35 percent of all TDCJ releases, and 98 percent of them were discharged while only 16 percent of state prisoners were. 
Figure 1.14. Percentage of sentence served, FY 1988 to FY 2002

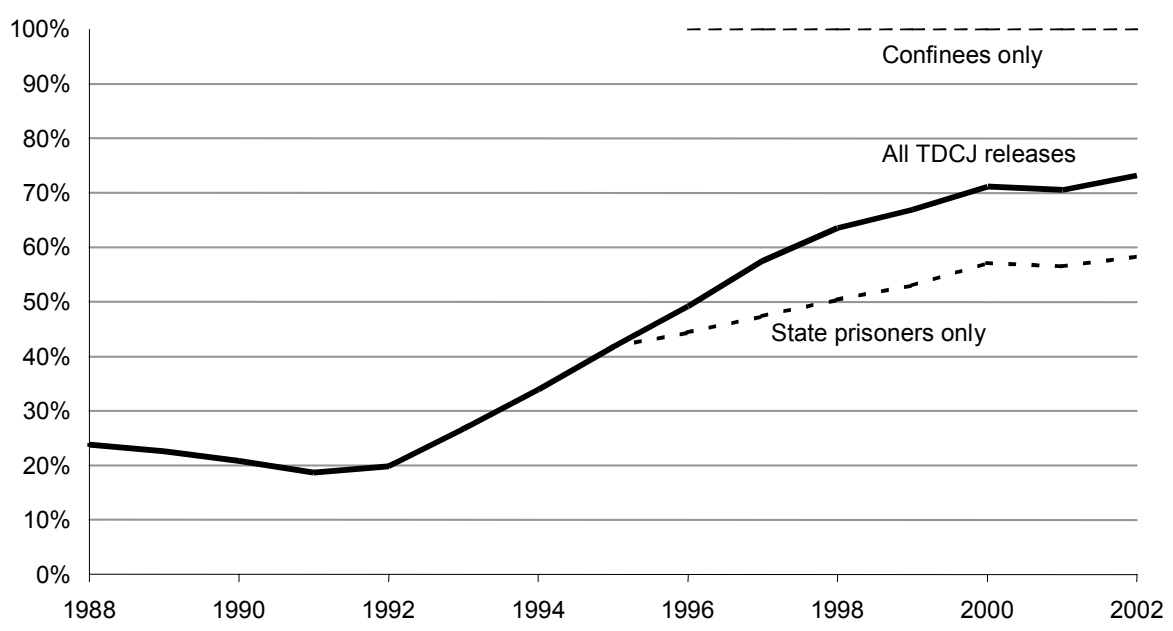

Source: Urban Institute analysis of Criminal Justice Policy Council data.

Figure 1.15. Parole approval rates, FY 1988 to FY 2002

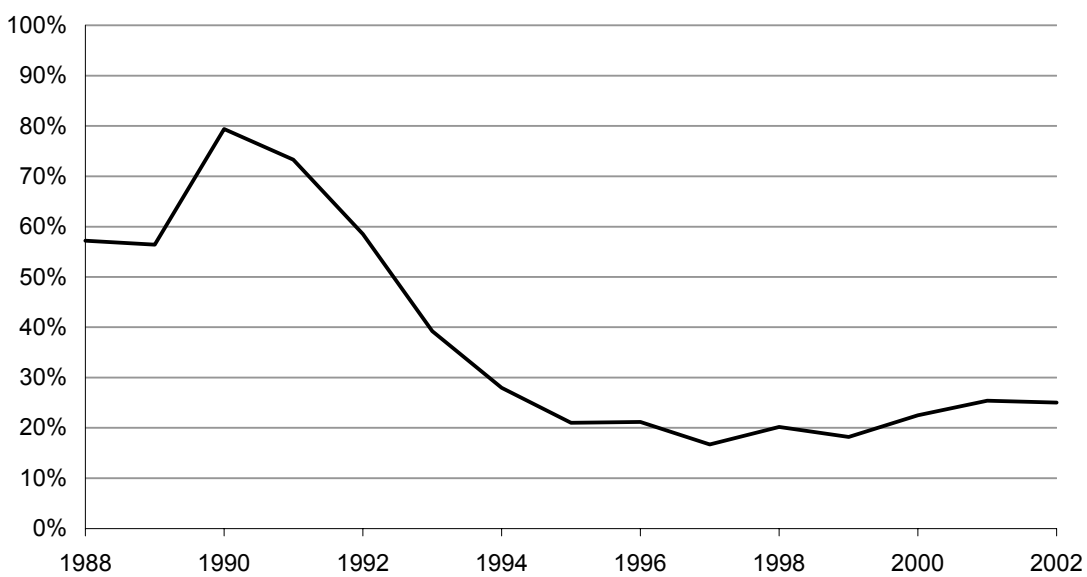

Source: Urban Institute analysis of Criminal Justice Policy Council data.

\section{Parole Eligibility and Approvals}

Falling parole approvals were the driving force behind the rise in prisoners' time served. ${ }^{51}$ Two main factors contributed to this decline. First, the percentage of releases who were eligible for parole dropped from nearly 100 percent in 1988 to approximately 63 percent in $2002 .^{52}$ Consequently, the number of prisoners considered for parole grew by just 24 percent while the prison population grew by 227 percent and releases grew by 73 percent. Second, for those prisoners considered for parole, parole approval rates plummeted from 57 percent to 25 percent during this time (figure 1.15). The result: the number of prisoners released to parole decreased by 45 percent, from 28,090 in 1988 to 15,426 in 2002.

The creation of the state jail felon category - a growing percentage of prisoners who are ineligible for parole - in 1993 likely reduced the proportion of prisoners considered for parole. 
Other factors also may have contributed to this result, such as resource constraints, an increasingly punitive political climate, changes in parole board members, and the increased housing capacity of TDCJ.

\section{Good-Conduct Time}

Eligible state prisoners can receive credit for good behavior (i.e., good-conduct time) for participating in programs and avoiding disciplinary reports; confinees cannot receive goodconduct time. ${ }^{53}$ These credits can affect a state prisoner's length of stay in two ways. First, as previously mentioned, some state prisoners are eligible for parole when their good-conduct time and time served sum to a percentage of their sentence. (Good-behavior credits are not considered when determining the parole eligibility date for state prisoners convicted of some aggravated offenses. ${ }^{54}$ ) Second, eligible state prisoners can still be released early through mandatory supervision (further described in chapters 4 and 5), which may occur when the prisoner's goodbehavior credits and time served sum to his sentence. ${ }^{55}$ The amount of good-conduct time a state prisoner can receive is not set, but CJPC staff reported that most state prisoners receiving goodconduct time receive one day of credit for each day served.

Although good-conduct time directly affects the time served by prisoners, changes in good-conduct time over the past decade did not likely contribute to the increase in prisoners' time served, since more prisoners are released today to mandatory supervision than were a decade ago. In 1988, 22 percent of all TDCJ releasees received mandatory supervision; in 2002, 29 percent did (figure 1.16).

Figure 1.16. Parole and mandatory supervision releases as percentage of all releases, FY 1988 to FY 2002

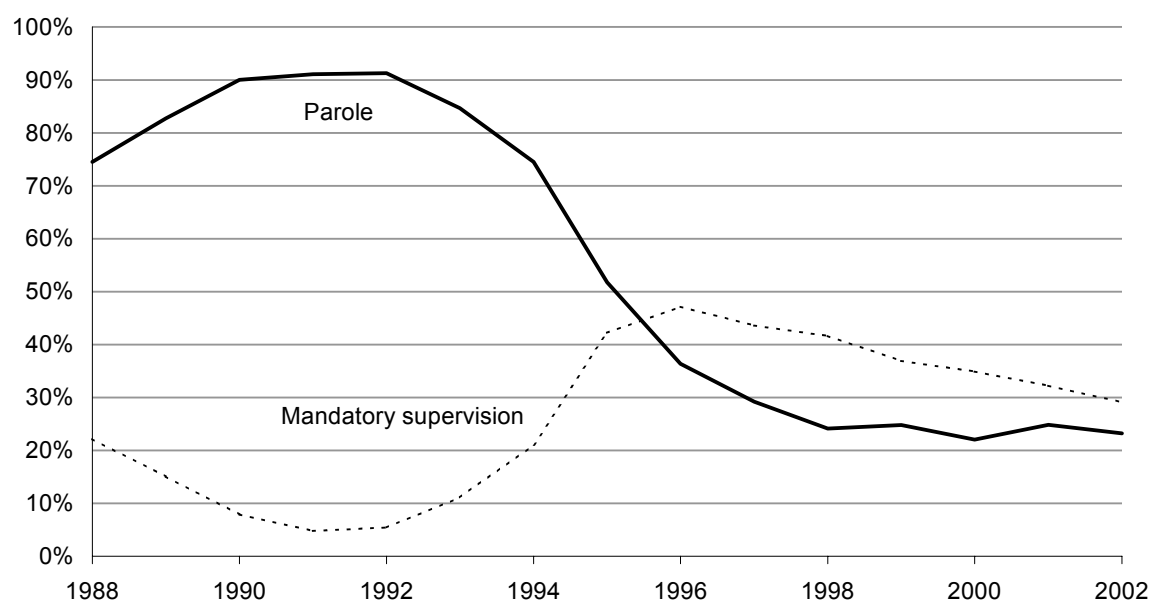

Source: Urban Institute analysis of Criminal Justice Policy Council data. 


\section{SUMMARY}

In summary, the state of Texas has experienced significant growth in its prison population and corrections spending. The prison population increase can be attributed to rising arrests, more convictions, longer sentences for most prisoners (state prisoners), falling parole approvals, and legislation requiring prisoners to serve longer portions of their sentences. From a reentry perspective, we can expect to observe two different types of released prisoners: (1) state prisoners who have spent longer periods of time in prison for drug, property, and violent crimes and (2) confinees who have spent shorter periods of time in state jails for drug and property crimes. The former group will likely have served long enough to have access to a variety of prison programs, including educational, vocational, employment, and substance abuse treatment programs. However, they will have been out of the workforce and disengaged from the community for a longer time, making the reentry adjustment a challenging one. Conversely, the latter group will have been released after serving very short sentences, making the disruption of incarceration less pronounced. However, these prisoners may have had less access to the programs and resources that TDCJ has to offer. These differences in reentry needs and challenges have implications for program structures, release policies, and postrelease supervision practices, topics that will be addressed in the chapters that follow. 


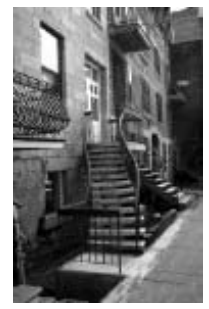

\section{H A P T E R 2 \\ Who Is Returning Home?}

s admissions to Texas prisons and state jails have increased over time, so too has the
number of prisoners being released from these facilities. To better understand prisoner
reentry in the state, it is important to examine the characteristics of the population being released from TDCJ each year. This section describes the 2001 release cohort, including basic demographics, reasons for incarceration, time served, transition to release, recidivism rates, and health challenges. ${ }^{56}$

\section{DEMOGRAPHICS}

In calendar year 2001, TDCJ released 55,183 men and women from its custody to the streets. ${ }^{57}$ Nearly all (99 percent, or 54,645) remained in Texas following release. ${ }^{58}$ The demographic characteristics of those released to Texas are similar to those of the state's standing prison population. The majority ( 86 percent) of the release population is male (figure 2.1). Nearly one in five prisoners are married. Almost half (44 percent) are non-Hispanic black, a third (32 percent) are non-Hispanic white, and a quarter (24 percent) are Hispanic (figure 2.2).

As figure 2.3 shows, nearly three-quarters (70 percent) of all releasees were less than 40 years old at release. Most were in their mid-30s at the time of their release, with the median age at release being 34. A little more than one-third (36 percent) were less than 30 years old at release. The youngest prisoner was 17 years old, and the oldest was 97.

Figure 2.1. TDCJ releasees by gender, 2001

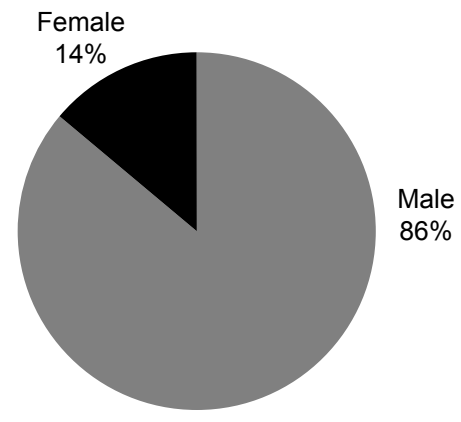

Source: Urban Institute analysis of 2001 TDCJ data.

Figure 2.2. TDCJ releasees by race/ethnicity, 2001

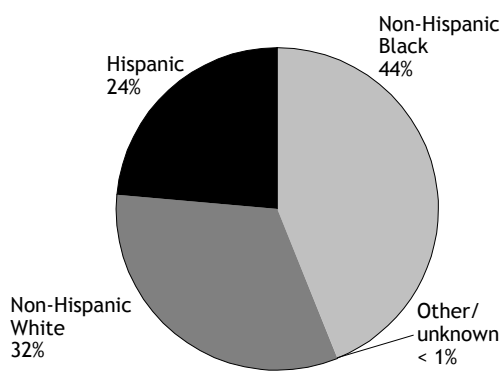

Source: Urban Institute analysis of 2001 TDCJ data.

Note: Figures total more than 100 percent due to rounding. 
Figure 2.3. TDCJ releasees by age, 2001

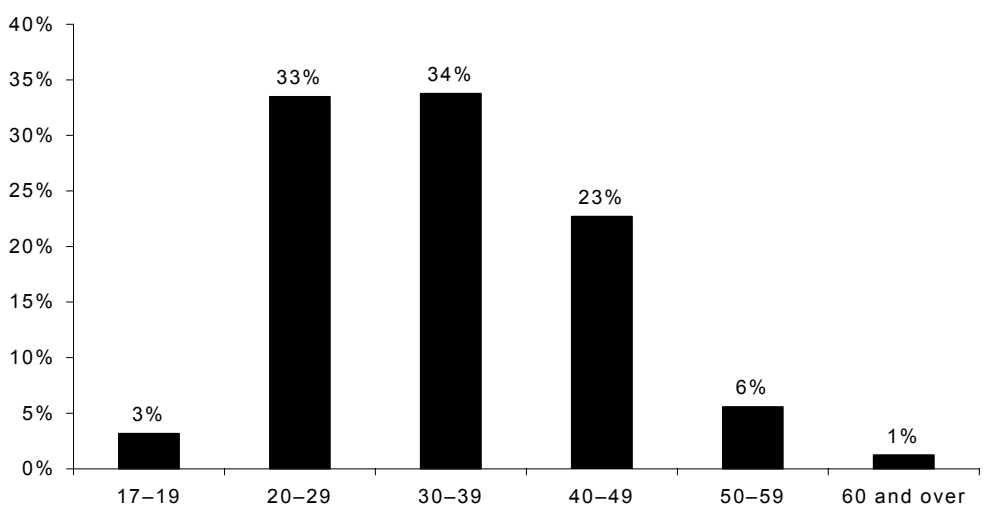

Source: Urban Institute analysis of 2001 TDCJ data.

Figure 2.4. TDCJ releasees by primary conviction offense, 2001

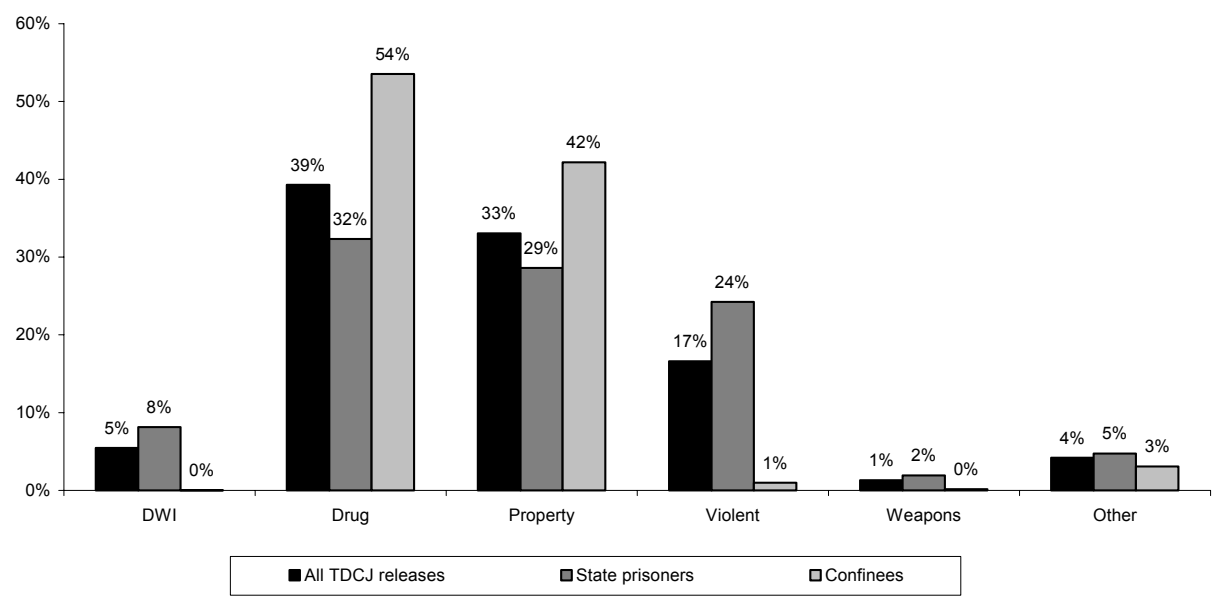

Source: Urban Institute analysis of 2001 TDCJ data.

Note: Percentages may not total 100 due to rounding.

\section{WHY THEY WERE INCARCERATED}

As described in the first chapter of this report, an increase in convictions for drug offenses has contributed to the growth in Texas's prison population. And, of prisoners released to Texas in 2001, drug offenses accounted for the greatest share of all convictions (figure 2.4). One in every 2.5 releasees (39 percent) had been incarcerated for either possessing or selling drugs; 1 in 3 releasees ( 33 percent) had been incarcerated for property offenses; and 1 in 6 releasees (17 percent) had been incarcerated for violent offenses. The remaining releasees had been incarcerated for such offenses as driving while intoxicated and weapons offenses.

Of those released to Texas, one-third $(18,107)$ had been serving time for a state jail, felony offense. See the sidebar, "Highlights of Differences between Confinees and State 
Prisoners," for a discussion of differences between these two populations, including differences in the offense types committed.

\section{Highlights of Differences between Confinees and State Prisoners Released in 2001}

- Twice as many confinee releasees as state prisoner releasees were women (21 versus 10 percent).

- Confinee releasees were slightly less likely than state prisoners to be white (30 versus 34 percent) or Hispanic (21 versus 25 percent) and more likely than state prisoners to be black (49 versus 41 percent).

- The median age of confinee releasees was slightly younger than that of state prisoners (31 versus 35).

- Compared with state prisoners, confinee releasees were significantly more likely to have been serving time for drug offenses ( 54 versus 32 percent), much more likely to have been serving time for property offenses (42 versus 29 percent), and significantly less likely to have been serving time for violent offenses (less than 1 versus 24 percent).

- On average, confinees were released after serving 11 months (100 percent of their sentences). In contrast, state prisoners were released after serving an average of 4.6 years (47 percent of the average sentence length of 9.7 years).

\section{HOW LONG THEY WERE INCARCERATED}

As discussed above, the average time served of Texas prisoners released in 2001 was 3.4 years and the average sentence length was 6.8 years. ${ }^{59}$ Slightly more than half ( 53 percent) of the Texas prisoners released in 2001 served two years or less in prison, 22 percent served between two and five years, and a quarter served five years or more. (For longitudinal trends on time served, refer back to figure 1.5.)

\section{TRANSITION TO RELEASE}

In 2001, the vast majority ( 85 percent) of prisoners released by TDCJ were released from a minimum custody level (figure 2.5). Confinees were only slightly more likely than state prisoners to be released from minimum custody ( 88 versus 83 percent). Consequently, most TDCJ prisoners are released with the benefit of a transition from a higher to a lower security level where they are able to participate in more programs and assume greater freedoms and responsibility, which may help prepare them for their release. 
Figure 2.5. Texas releasees by custody at release, 2001

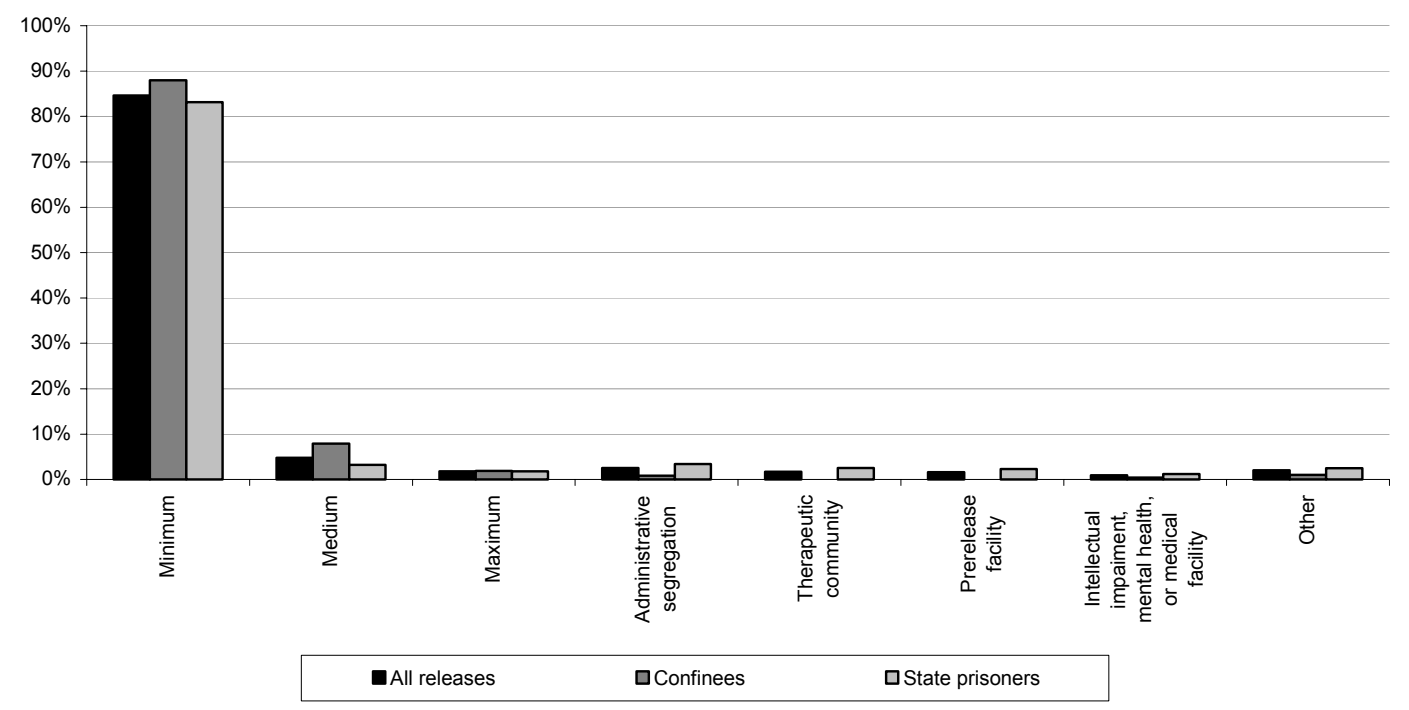

Source: Urban Institute analysis of 2001 TDCJ data.

\section{RECIDIVISM AND THE REVOLVING DOOR}

Cycling in and out of prison is common among released state prisoners, whether they are returned to prison while under parole supervision or not. A recently released study by the Bureau of Justice Statistics that tracked state prisoners released from prisons in 15 states in 1994 found that within three years of their release, nearly 52 percent were back in prison for new prison sentences or technical violations of the conditions of their release. ${ }^{60}$

The criminal histories of the released state prisoners in Texas demonstrate slightly lower patterns of reincarceration: within three years of release, 41 percent of state prisoners released in 1994 returned to a state prison or state jail facility. ${ }^{61}$ By 1998 , the percentage of state prisoners who had been reincarcerated within three years had dropped to 31 percent - the lowest recidivism rate in a decade. To compare reincarceration rates of state prisoners with confinees, we must examine two-year reincarceration rates since those are the only data available for confinees. Of the confinees released in 1998, 19 percent were reincarcerated in two years; state prisoners released in 1998 were only slightly more likely (21 percent) to be reincarcerated within this period. $^{62}$ Notably, confinees released to supervision are significantly more likely to be reincarcerated than those who are simply discharged. For example, 17 percent of confinees released in 1998 without supervision were reincarcerated-less than half the rate at which confinees released to supervision were (39 percent). ${ }^{63}$ Data comparing the recidivism rates of state prisoners released to supervision with those not released to supervision are unavailable.

Also, one in four Texas prisoners released in 2001 had been incarcerated as a parole, mandatory supervision, or shock probation violator. The percentage of prisoner releasees who, at incarceration, had violated felony probation is not available - although the percentage is expected to be high given felony probation revocation trends (see figure 1.12). 


\section{MENTAL AND PHYSICAL HEALTH PROBLEMS}

State prisoners nationwide suffer from a range of mental and physical health problems. In 1997, nearly one-third (31 percent) of state prisoners nationally reported having a learning or speech disability, a hearing or vision problem, or a mental or physical condition. ${ }^{64}$ The physical health challenges, along with the related fiscal costs, are rising due to the changing demographics of the prison population in Texas. The CJPC found a substantial increase since 1994 in the elderly prison population (ages 55 and older) - a population that tends to experience health problems at a higher rate than the average prisoner. ${ }^{65}$ In fiscal year 2000, the cost of managed health care in Texas reached over $\$ 267$ million (11 percent of TDCJ's $\$ 2.4$ billion budget). ${ }^{6}$

A specific area of heightened concern is HIV/AIDS in prison populations. Nationally, in 2000, 2 percent of state prisoners were HIV positive, and the overall rate of confirmed AIDS cases among the nation's prison population was four times the rate in the U.S. general population (0.52 percent versus 0.13 percent) ${ }^{67}$ In Texas, 1.9 percent of prisoners were HIV positive in $2000{ }^{68}$ The reentry challenge of HIV/AIDS is particularly significant considering the findings of a 2000 study conducted by Dr. William O'Brien, a researcher at the University of Texas Medical Branch in Galveston (UTMB). ${ }^{69}$ This study found that TDCJ prisoners were developing resistance to an HIV/AIDS medication as a result of inconsistent administration of the drug. ${ }^{70}$ While the authors were unable to obtain detailed statistics on other health characteristics of Texas prisoners, ${ }^{71}$ it stands to reason that the state's soon-to-be-released state prisoners have rates of other physical conditions similar to those of prisoners across the country. ${ }^{72}$

CJPC studies have shown that mental health issues pose an increasingly significant challenge to TDCJ. Between 1988 and 1998, the total number of TDCJ state prisoners receiving mental health care (whether on inpatient or outpatient caseloads) increased by 399 percent (from 3,148 to 15,716 ). At the same time, the number of psychiatric beds available increased by 157 percent (from 823 to 2,116 ), and the overall prison population increased by 262 percent (from $39,664$ to 143,803$).^{73}$ The vast majority of prisoners with mental health issues were served in outpatient facilities. ${ }^{74}$ In fiscal year 2000, the cost of psychiatric care totaled $\$ 43$ million (nearly 2 percent of TDCJ's budget). ${ }^{75}$

Mental health issues are also prevalent in the parole and probation population. In 2001, 575,548 individuals were under direct parole or probation supervision in Texas; of these individuals, an estimated 16 percent $(91,603)$ suffered from a mental illness. ${ }^{76}$ Twenty-seven percent (or 29,948 of 110,692) of all direct parolees are estimated to be mentally ill and 13 percent (or 61,655 of 464,856) of direct probationers are. At the same time, 28 percent $(25,562)$ of mentally ill probationers and parolees were treated: 19 percent received services from the state's Mental Health and Mental Retardation programs and 9 percent received services from the criminal justice system mental health services.

Thus, mental and physical health issues experienced by Texas state prisoners present yet another reentry challenge and public health opportunity. 



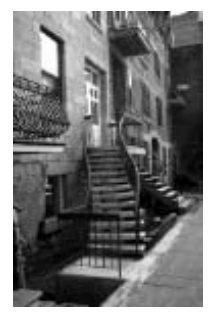

\section{H A P TER 3 \\ How Are Prisoners Prepared for Reentry?}

$\mathrm{H}$

istorically, prison programs have played an important role in American corrections. Whether prison programs do, in fact, contribute to positive postrelease outcomes (e.g., reduced recidivism and long-term employment) has been the subject of much research and dispute. In the 1970s, studies suggested that prison programs did not work. ${ }^{77}$ By contrast, more recent research and meta-analyses have found favorable results, with treatment groups across programs consistently achieving at least modest reductions in recidivism versus comparison groups, particularly when coupled with programs in the community. $^{78}$

Despite the potential benefits of facility-based programs, participation in prison programs nationwide is on the decline. The number of soon-to-be-released state and federal prisoners who reported participating in vocational programs dropped from 31 percent in 1991 to

\section{TDCJ Placement Process}

With the exception of those prisoners sentenced to a Substance Abuse Felony Punishment facility, prisoners receive an Individualized Treatment Plan at admission. This plan outlines the programs appropriate for the individual. When determining priority for placement in programs, preference is given to prisoners approved for parole and required to complete a treatment program. Other prisoners are categorized based on projected release date, age, custody level, level of need, whether the program is offered in the prisoner's institution, and the availability of space in the program.

27 percent in $1997 .{ }^{79}$ Similarly, the number who reported participating in education programs dropped from 43 to 35 percent in that same period. ${ }^{80}$ The number of prisoners who reported receiving formal substance abuse treatment also dropped, from 25 percent in 1991 to 10 percent in $1997 .^{81}$ These numbers are discouraging given the suggested benefit of in-prison programs and the increasing number of prisoners who are in need of training and treatment.

\section{OVERVIEW OF TDCJ PROGRAMS}

TDCJ prisoners have access to a range of programs and services - including education programs, vocational training, substance abuse treatment, behavior-modification programs, and mental health counseling - designed to help them reintegrate into communities and reconnect with their families. 
Figure 3.1 shows that over $\$ 241$ million was devoted to in-prison programs in Texas in fiscal year 2000. ${ }^{82}$ These funds come from the budgets of TDCJ and the Windham School District (WSD), TDCJ's primary educational and vocational program provider. The vast majority of these funds are devoted to educational, work, and substance abuse treatment programs. Seven percent of TDCJ's budget (nearly $\$ 165$ million) is devoted to institutional programs. Of TDCJ's budget, 3.2 percent is devoted to correctional industries (work programs); 2.8 percent is allocated to inprison substance abuse treatment; 0.2 percent is devoted to academic and educational programs; 0.1 percent is for Project RIO, a vocational skill program; and 0.6 percent is devoted to other institutional inmate treatment services such as sex offender treatment programs. To assist with the transition from corrections to the community, TDCJ also provides some programs to prisoners in the community following release (both residential and nonresidential), but funding totals for these programs were unavailable. In addition, WSD reports spending over \$76.4 million for educational and academic programs in fiscal year $2000 .{ }^{83}$ Of these funds, 83 percent was devoted to education programs in state prisons, 12 percent was devoted to education programs in state jails, 4 percent was devoted to continuing education programs, and 0.3 percent was devoted to education programs in parole facilities. ${ }^{84}$

\section{Figure 3.1. Key TDCJ prisoner program categories by budget, FY 2000}

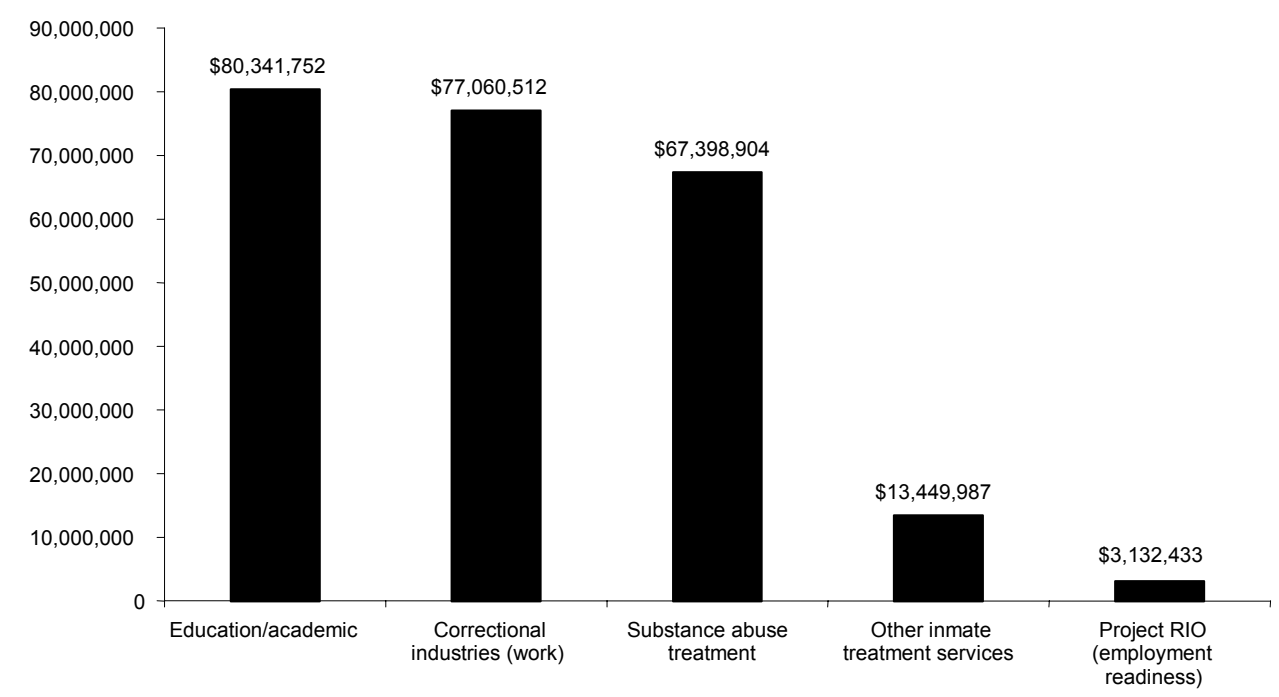

Source: Urban Institute analysis of TDCJ, Texas Board of Pardons and Parole, and Criminal Justice Policy Council data.

In fiscal year 2004, however, TDCJ's budget for programs - specifically substance abuse treatment programs, academic programs, and chaplaincy-dropped 16 percent due to Texas's budget deficit. ${ }^{85}$ Overall, TDCJ's budget fell 5 percent from fiscal year 2003 to fiscal year $2004 .{ }^{86}$ As a result, Texas prisoners face fewer opportunities to participate in programs today than in recent years. Further, prisoners may have fewer incentives today to participate in programs than they did a decade ago, since parole approvals, which include program participation as a consideration factor, are less likely now than they were a decade ago. 
While no historical data exist on program participation in Texas, and current data are sometimes incomplete, we are able to report some estimates of prisoner participation in programs. WSD reports that 83,337 prisoners ( 42 percent of possible participants in fiscal year 2002) participated in its basic educational programs in fiscal year $2002 .^{87}$ In addition, 12,463 prisoners $(6$ percent of possible participants in fiscal year 2002) participated in WSD's college-level courses and vocational classes. In 2002, at least 9,000 prisoners (5 percent of potential participants in fiscal year 2002) were admitted to substance abuse programs prior to release, and at least 8,700 prisoners could have participated in postrelease inpatient substance abuse programs (not including those prisoners who received field referral services). However, many more prisoners may have participated in substance abuse programs since most of TDCJ's substance abuse programs do not publish
About Program Participation Data

Unless otherwise noted, individual program participation and admission rates are unique. Because prisoners may have participated in multiple programs, we are unable to combine or average rates across program types with any accuracy. For example, combining participation rates across programs in the Windham School District would count more than once prisoners who participated in more than one program and overestimate the number of individuals who accessed education programs.

participation rates. Also, 85 percent of prisoners participate in work assignments at any given time, and 69,506 prisoners (35 percent of potential participants in fiscal year 2002) participated in Project RIO, a prerelease and postrelease work-readiness program (figure 3.2).

Figure 3.2 provides a summary of the main TDCJ programs and services offered to prisoners incarcerated in TDCJ facilities - both in traditional correctional institutions and in community-based facilities. ${ }^{88}$ We provide a more in-depth description of these programs below. While we include descriptions of programs administered by TDCJ Parole Division, we do not do so for those programs administered by TDCJ Community Justice Assistance Division (the probation department) because so few TDCJ prisoners (approximately 2 percent) are released to probation.

\section{EDUCATION PROGRAMS}

Data on the nation's prison populations suggest that the education level of state prisoners is well below that of the general population. ${ }^{89}$ While 18 percent of the general population had not completed high school or received an equivalency degree in 1997, 40 percent of prisoners in state or federal prison had not done so. ${ }^{90}$ In Texas, 43 percent of state prisoners admitted in 2000 did not possess a high school diploma or general equivalency diploma (GED). ${ }^{91}$ Even more

\section{Education Programs}

- Basic Education

- College Coursework

- Community Opportunities Programs in Education 


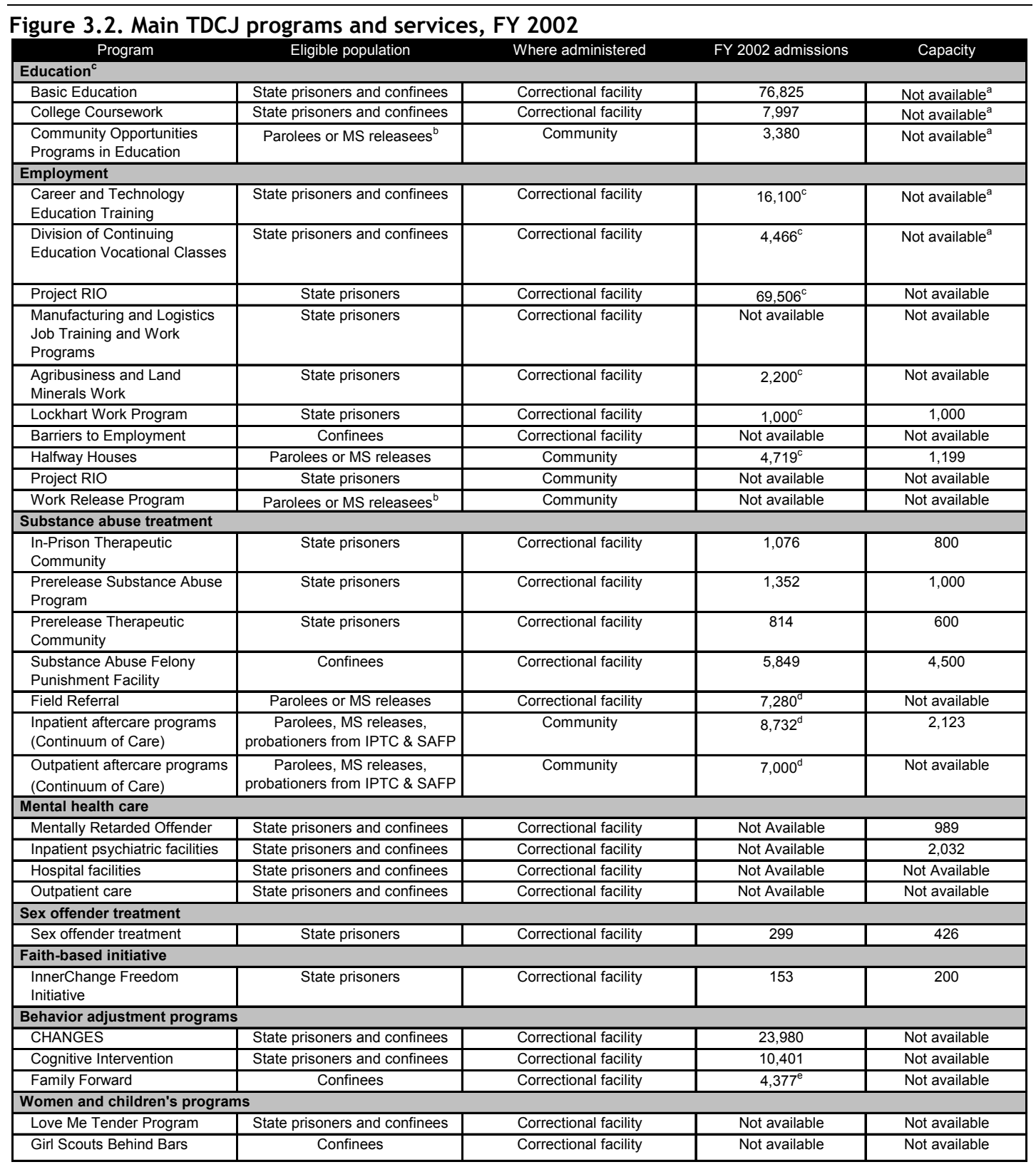

Source: Urban Institute analysis of TDCJ, Texas Board of Pardons and Parole, and CJPC data.

${ }^{a}$ The total capacity of all WSD vocational and educational programs is approximately 30,000 . Since some inmates participate in multiple programs, the participation totals listed above may double count inmates admitted; as a result, the total number of education participants listed above will not sum to the total number of unique inmates participating in these programs that is listed in the chapter.

${ }^{\mathrm{b}} \mathrm{MS}$ signifies mandatory supervision release.

'Program participants.

${ }^{\mathrm{d}}$ Estimated from program capacity and average length of stay.

${ }^{\mathrm{e}} \mathrm{FY} 2003$. 
striking is the fact that, in 2002, 31 percent of state prisoners in Texas prisons could be defined as functionally illiterate. ${ }^{92}$

Since 1969, WSD has served as the primary administrator of educational and vocational programs for TDCJ. WSD operates as an independent school district under the dual supervision of TDCJ and the Texas Education Authority. In the 2001 to 2002 school year, WSD had 83,337 participants in WSD educational or vocational programs (42) percent of potential participants). ${ }^{93}$ Overall, WSD has the capacity to serve approximately 30,000 prisoners at any given time through its 88 schools in TDCJ facilities. ${ }^{94}$ WSD also reports that 5,347 GEDs and 509 advanced degrees were conferred to TDCJ prisoners in 2002 (figure 3.3).

On average, prisoners receive the equivalent of one school year (604 hours) of educational programming during their stay in prison; placement preference is given to those prisoners required to participate in programs prior to parole release, those nearing their release, those who are young, and those with the greatest need for education programs. ${ }^{95}$ The following is a brief description of the education programs offered through the TDCJ. ${ }^{96}$

\section{Administered in Correctional Facilities}

- Basic Education. WSD's Division of Instruction offers basic academic programs from primary to secondary schooling and includes literacy programs, English as a second language classes, and special education classes for prisoners with special needs. Among these programs, the literacy program is the most widely accessed. In the 2001 to 2002 school year, 52,639 (26 percent of potential participants in fiscal year 2002) enrolled in the literacy program. This program targets adults who are considered functionally illiterate or who are pursuing a GED. Most basic education programs require a commitment of approximately 15 hours per week of class time.

- College Coursework. The Division of Continuing Education offers college-level coursework through partnerships with 16 two-year and 3 four-year colleges and universities. Prisoners who participate receive college credit for their courses. Approximately 4 percent of the possible participants took advantage of higher-level academic courses during the 2001 to 2002 school year. WSD does not fund collegelevel courses. Outside sources and the prisoners themselves fund these courses. In 2002, 509 college degrees (associate's, bachelor's, and master's degrees) were awarded. 
Figure 3.3. Academic degrees awarded to TDCJ prisoners by WSD, FY 2002

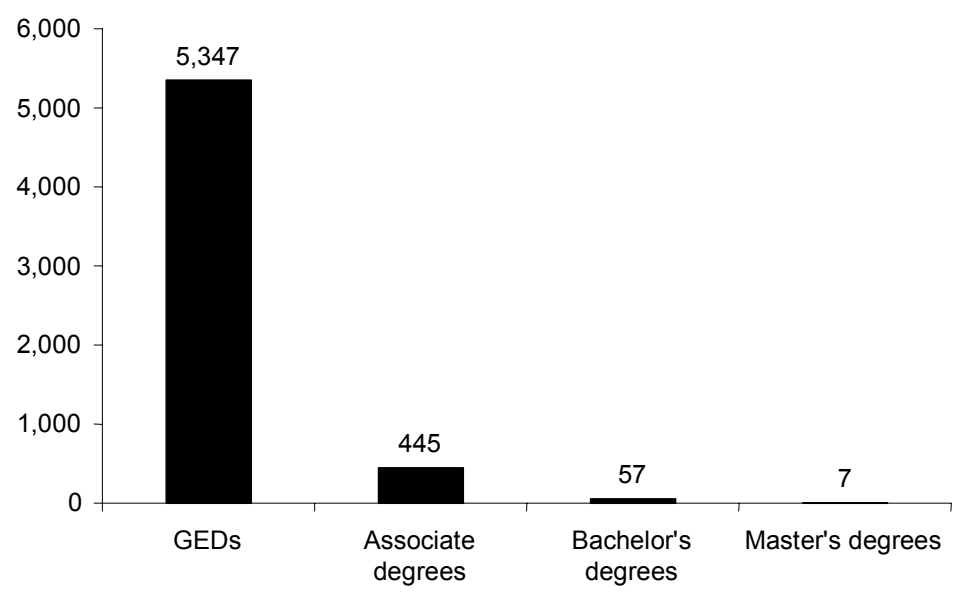

Source: Urban Institute analysis of TDCJ data.

\section{Administered in the Community}

- Community Opportunities Programs in Education (COPE) Program. ${ }^{97}$ Upon release, parolees with low academic achievement levels or who wish to earn their GED are eligible to participate in the Parole Division's COPE Program. A substantial proportion of parolees meet this qualification: Of the 13,200 prisoners released to parole in fiscal year 2002, 44 percent had not earned a high school diploma or GED. By the end of fiscal year 2002, 3,380 offenders (26 percent of the prisoners released to parole in that fiscal year), had enrolled in this program. ${ }^{98}$

\section{EMPLOYMENT-READINESS PROGRAMS}

The difficulties prisoners face within the labor market, before incarceration, and after release have been well documented. ${ }^{99}$ Prisoners often enter prison with poor educational backgrounds and unstable work histories. While incarcerated, they lose the opportunity for valuable work experience and may sever interpersonal connections that could provide links to employment opportunities. ${ }^{100}$ These obstacles to finding legitimate employment add to the reintegration challenges facing returning state prisoners.

Employment-readiness programs are programs designed to help prisoners overcome the barriers to employment and prepare them for reentry into the workforce. WSD and TDCJ's Manufacturing and Logistics Division

\section{Employment-Readiness Programs}

- Career and Technology Education

- Division of Continuing Education Vocational Classes

- Project RIO

- Manufacturing and Logistics Job Training

- Agribusiness and Land Minerals

- Lockhart Work Program

- Barriers to Employment

- Halfway House Programs

- Work Release Program 
offer several in-prison occupational training and career development programs. As of fiscal year 2002, more than 90,000 prisoners were enrolled in WSD employment programs (including 69,506 reported Project RIO participants), and more than 7,300 were involved in employment programs through the Manufacturing and Logistics Division. ${ }^{101}$ Thus, at least 97,300 prisoners could have participated in these programs during this time. ${ }^{102}$ WSD also reports that 13,118 vocational certificates were conferred to TDCJ prisoners in 2002 and that WSD students earned 2,731 industry certificates. A brief overview of some of the main TDCJ work programs follows.

\section{Administered in Correctional Facilities ${ }^{103}$}

- Career and Technology Education (CTE). CTE offers occupational training courses to participating prisoners. While the program operates in most adult institutions, only 8 percent of potential participants in fiscal year 2002 participated in CTE programs. ${ }^{104}$ Courses are offered in 34 subject areas that range from electrical trades and plumbing to graphic arts and information technology. ${ }^{105}$ The full training program entails 600 hours of coursework and provides entry-level industry training, while the short training program (for prisoners with specific occupational needs or who will be released shortly) entails 45 to 200 hours of coursework. CTE also offers an apprenticeship program and on-the-job training.

- Division of Continuing Education Vocational Classes. The Division of Continuing Education offers prisoners vocational education classes to earn credits for college or toward vocational certification. These classes are offered in 29 TDCJ units and cover such topics as advanced horticulture, electronics, and masonry. But only 2 percent of potential participants in fiscal year 2002 participated in vocational credit courses through the continuing education program.

- Project RIO (Re-Integration of Offenders). Project RIO is a prerelease and postrelease program created in 1985 that works to reduce recidivism by connecting prisoners to jobs. WSD administers the prerelease component of this program that includes assisting prisoners to obtain the necessary documentation-such as social security cards, birth certificates, and driver's licenses - to secure employment. WSD staff members also help participants develop a postrelease plan to find and secure employment and refer them to appropriate in-prison education, vocational training, and substance abuse programs. Of the 58,949 state prisoners and confinees released in fiscal year 2002, nearly 35 percent of possible participants had developed plans to seek services and employment after release through Project RIO.

- Manufacturing and Logistics Job Training and Work Programs. TDCJ's Manufacturing and Logistics Division offers work programs and some on-the-job 
training and certification to prisoners. The products manufactured by prisoners and services are provided free-of-charge or at a reduced cost to the TDCJ and to other public agencies. Prisoners can work in the division's varied industries: movement of freight, managing storage facilities, and management and maintenance of TDCJ's automobiles. Prisoners can also receive training and certification in Geographic Information Systems, computer repair, and braille transcription through the Manufacturing and Logistics Division; in 2002, 49 prisoners were certified in one of these areas. In partnership with the Texas Correctional Industries, the division also employs around 7,300 prisoners in 40 factories that manufacture a variety of products, including mattresses, shoes, brooms, furniture, and steel products.

- Agribusiness and Land Minerals. This division employs 2,200 offenders in agriculturally based jobs throughout the state of Texas. Prisoners are employed in various positions, including farming, tending livestock, and harvesting produce.

- Lockhart Work Program. Located in a secure facility within the TDCJ prison system, the Lockhart work program employs inmates in a variety of industries that include manufacturing air conditioner parts, computer components, medical gowns, and designer lenses and frames under the Private Sector/Prison Industries Enhancement Program (PIE). This federally funded program excludes the industries located at Lockhart from federal constraints placed on offender-made goods. In addition, the PIE program stipulates that a portion of the income prisoners earn is donated toward facility maintenance, victim restitution, and family support. Prisoners are able to participate in much of the same programming offered in other prison facilities, such as educational, vocational, and life skills programs. Lockhart prison has a capacity of 1,000 men and women.

- Barriers to Employment. This program, offered at the Joe Kegans State Jail in Houston, offers transitional programming to help confinees reintegrate into the community. Offenders that qualify for the program transfer to the Kegans facility prior to release. There they are provided with prerelease counseling and services. Specifically, the Barriers to Employment program, in partnership with Career and Recovery Resources (a United Way Agency) offers career and employment readiness counseling that teaches prisoners how to write a résumé, secure and maintain employment, and utilize local resources to find employment. ${ }^{106}$

\section{Administered in the Community}

- Halfway House Programs. There are currently seven halfway houses for parolees and mandatory supervision releases across Texas, all of which are contracted to private 
nonprofit or for-profit entities. In addition to providing shelter to just-released prisoners, halfway houses often provide other transitional services, such as employment counseling and referrals. Prisoners must remain on the property at all times (unless reporting to their designated place of employment) and contribute a portion of their earnings to the maintenance of the facility. Prisoners are also required to remain in the halfway house facility until the proper authorities grant permission to leave. In fiscal year 2002, these facilities had a capacity to house 1,199 parole and mandatory supervision releasees at any given time. ${ }^{107}$ During this fiscal year, 4,719 parole and mandatory supervision releasees were released from these facilities. ${ }^{108}$

- Work Release Program. Some Texas counties administer a work release program offered to prisoners released to parole or mandatory supervision who are returning to nonmetropolitan areas that may lack a halfway house program. Prisoners reside in county jail facilities and follow similar rules to their counterparts in halfway house programs. Local divisions of the TDCJ Parole Division administer this program.

- Project RIO. The Texas Workforce Commission implements the community-based component of Project RIO. Project RIO helps ex-prisoners complete their Individual Strategy and Service Development Plan developed during their incarceration. Project RIO staff offer job-search assistance, workshops on résumé building and interviewing, work referrals, and job fairs. Project RIO staff also work to educate employers about the referral process and its benefits; they also provide a financial incentive program for employers who hire certain ex-prisoners. ${ }^{109}$

\section{SUBSTANCE ABUSE TREATMENT PROGRAMS}

The relationship between substance abuse and incarceration has drawn the attention of national and state officials alike. Studies have found that more than half of state prisoners across the nation reported that they were under the influence of drugs or alcohol at the time they committed the offense that led to their imprisonment. ${ }^{110}$ Furthermore, 74 percent of state prisoners nationwide who expected to be released in the year 2000 reported a history of drug and/or alcohol abuse. ${ }^{111}$

The issues surrounding substance abuse in Texas largely mirror those of the nation. A recent study found that 63 percent of state prisoners are substance users or chemically dependent and that 39 percent of state prisoners reported being intoxicated during the commission of their crime. ${ }^{112}$ At the same time, 5 percent of potential prisoner

Substance Abuse Treatment Programs

- In-Prison Therapeutic Community

- Prerelease Substance Abuse Program

- Prerelease Therapeutic Community

- Substance Abuse Felony Punishment Facility

- Aftercare Programs

- Field Referral 
participants are known to have been admitted to substance abuse programs in fiscal year 2002 . We expect that a significant number of prisoners have attended voluntary self-help programs such as Alcoholics Anonymous, Narcotics Anonymous, counseling sessions, and Secular Organization for Sobriety programs. ${ }^{113}$ However, the availability of these programs to prisoners depends on the number of volunteers available at any given time. Participation rates for these programs are unavailable.

Now we turn to a brief description of the TDCJ Programs and Services Division's four substance abuse programs. Together, these programs have a capacity to serve 6,900 prisoners at any given time and are located in 19 of TDCJ's 105 units. Combined, the four programs served 5 percent of potential participants in fiscal year 2002. Evaluations conducted by the Criminal Justice Policy Council suggest that these models have positive effects on the prisoners they serve. ${ }^{114}$ Below, we provide an overview of substance abuse programs and opportunities for released prisoners to find substance use treatment once they return to the community.

\section{Administered in Correctional Facilities}

- In-Prison Therapeutic Community Program (IPTC). IPTC is designed for paroleapproved state prisoners within 12 to 14 months of their release who suffer from substance abuse. IPTC is mandatory for those selected by the parole board to participate; these prisoners must complete the nine-month program as a condition of release to parole. IPTC has a program capacity of 800 prisoners (500 male and 300 female) and admitted 1,076 offenders in fiscal year 2002. The Criminal Justice Policy Council (CJPC) reports that within a sample population, the recidivism rates of state prisoners who successfully completed IPTC are lower than for those who did not complete IPTC. In 1994, CJPC reported that 63 percent of prisoners in the sample studied completed both in-prison and postrelease treatment components of the IPTC program. Following the implementation of several procedural changes, completion rates have increased since this time. ${ }^{115}$

- Pre-Release Substance Abuse Program (PRSAP). Operating since 1996, this program follows a six-month curriculum that includes counseling, anger-management training, life skills training, and drug and alcohol education. PRSAP works with 1,000 mandatory supervision and parole-approved prisoners who will be released to parole. PRSAP admitted 1,352 prisoners in fiscal year 2002. According to a 2003 CJPC report, within the sample studied, PRSAP reduced recidivism rates among participating prisoners, particularly among those who were considered at high risk of recidivating. The PRSAP program has the highest completion rate of all substance abuse programs; 85 percent of the sample population completed the six-month curriculum. 
- Pre-Release Therapeutic Community (PRTC). Established in 1997, the PRTC program targets mandatory supervision or parole-approved state prisoners returning to the Dallas area. The program curriculum includes six months of substance abuse treatment, vocational and academic courses, and life skills training workshops. PRTC has the capacity to serve 600 prisoners at any given time and served 814 prisoners in fiscal year 2002. CJPC found that recidivism rates are generally lower for prisoners who complete the entire PRTC program and found that 61 percent of participants do so. According to CJPC, for the sample studied in 2003, factors unrelated to program activities (namely staffing shortages and multiple program goals) may have lessened PRTC's effectiveness.

- Substance Abuse Felony Punishment Facilities (SAFP). Confinees, probationers, and parolees with substance use issues may be sentenced directly to SAFPs. Offenders sentenced to SAFP facilities serve six-month sentences in a SAFP facility, are required to complete three months of treatment after release in an inpatient substance abuse treatment facility, and are encouraged to participate in up to nine months of outpatient care. ${ }^{116}$ While incarcerated in a SAFP facility, offenders are under 24-hour supervision and are provided various types of substance abuse treatment education, cognitive intervention courses, life skills training, and other positive components geared toward successful reintegration and a crime-free, drug-free lifestyle. At the end of fiscal year 2002, SAFP had a 4,500-bed capacity with 500 beds reserved for parolees; the program admitted 5,849 offenders in fiscal year 2002. According to a CJPC evaluation, the recidivism rates for a sample of SAFP participants and nonparticipants are very similar over time (32 percent for participants and 30 percent for the comparison group); however, they also reported that the recidivism rate for prisoners who complete all components of the two-year program drops to 5 percent. Additionally, "CJPC estimates that for every 100 prisoners placed in the SAFP program the state avoids $\$ 770,000$ in incarceration costs." 117 While 68 percent of the sample prison population completed one month of the three-month outpatient treatment program, only 44 percent completed all in-prison and postrelease program components. ${ }^{118} \mathrm{CJPC}$ also reported a disproportionate number of revocations due to technical violations of parole or probation among SAFP participants; violators accounted for 55 percent of SAFP recidivists.

\section{Administered in the Community}

Studies have shown that substance abuse treatment programs are most effective when they encompass an in-prison treatment component as well as an aftercare component. ${ }^{119}$ Following this research, the community-based programs run by the Parole Division complement the variety of in-prison programs provided by the Programs and Services Division. 
- Aftercare Programs (Continuum of Care Programs). Parolees and mandatory supervision releasees who participated in the In-Prison Therapeutic Community (IPTC) program and probationers who were incarcerated in a Substance Abuse Felony Punishment (SAFP) facility participate in this program. IPTC and SAFP programs require participants to seek three to nine months of substance abuse treatment following release. TDCJ administers both the inpatient and outpatient care. The inpatient aftercare program has a program capacity of 2,183 and serves approximately 8,732 prisoners per year. ${ }^{120}$ The outpatient substance abuse program, coordinated by the Programs and Services Division, serves approximately 7,000 parolees and probationers per year. ${ }^{121}$

- Field Referral. For parolees and mandatory supervision releasees at risk of substance abuse who did not participate in IPTC or SAFP, the Division of Parole provides the Field Referral program. After release, a field officer assesses a prisoner's substance abuse treatment needs and refers him or her to the appropriate treatment facility or program. Since 52 percent of all releasees were released to parole or mandatory supervision, many TDCJ ex-prisoners have access to this service. The field referral program has access to 395 inpatient beds, which serve approximately 1,580 prisoners per year. ${ }^{122}$ The outpatient program serves approximately 5,700 parole or mandatory supervision releasees per year. ${ }^{123}$

\section{MENTAL HEALTH CARE}

The United States Department of Justice reports that almost 16 percent of state prisoners nationwide suffer from mental illness. ${ }^{124}$ Although the percentage of Texas prisoners receiving mental health care in 1998 (slightly under 11 percent) was below the national average, the number of prisoners under mental health supervision in Texas had increased fivefold in 10 years. From 1988 to 1998, the number of Texas prisoners under mental health supervision grew from 3,148 to $15,716 .{ }^{125}$

- Hospitals. TDCJ prisoners have access to two secure hospitals - the Young Medical Facility and Hospital

Mental Health Care Options

- Hospitals

- Outpatient Care

- Basic Mental Health Care

- Inpatient Psychiatric Units

- Mentally Retarded Offender Program Galveston. The University of Texas Medical Branch manages both facilities. Both hospitals provide mental health services and ambulatory, surgical, and specialty care for prisoners. At the end of fiscal year 2001, there were 459 prisoners incarcerated in TDCJ hospital facilities. ${ }^{126}$ 
- Outpatient Care. Most prisoners with mental health challenges received outpatient care. In 1988, 2,589 TDCJ prisoners (82 percent of the mental health population) received outpatient care. A decade later, in 1998, 13,691 TDCJ prisoners (87 percent of the mental health population) received outpatient care. ${ }^{127}$

- Basic Mental Health Care. Every Texas correctional institution provides prisoners with basic mental health care, which can include diagnosis, provision of psychiatric medication, and counseling. ${ }^{128}$ Each facility has either mental health professionals on staff or contracts with outside entities to provide psychological and psychiatric testing, examinations, and diagnostic services.

- Inpatient Psychiatric Units. Prisoners with significant mental health challenges may receive more intensive care in one of four inpatient psychiatric units. Prisoners with serious psychiatric needs are placed in psychiatric units in three correctional facilities (Jester IV, Montford, and Skyview), and the Program for Aggressive Mentally Ill Offenders (PAMIO) operates in a fourth unit (Clements). PAMIO is a 450-bed, inpatient psychiatric facility for administrative segregation prisoners. ${ }^{129}$ These four units can serve up to 2,032 state prisoners and had a population of 1,932 at the end of fiscal year 2002. ${ }^{130}$

- Mentally Retarded Offender Program. Prisoners with mental retardation and developmental challenges are placed in the Mentally Retarded Offender Program, which is located in two facilities and has the capacity to serve 989 prisoners at a time. ${ }^{131}$ At the end of fiscal year 2002, this program held 897 prisoners.

\section{SEX OFFENDER TREATMENT PROGRAM}

The Sex Offender Treatment Program (SOTP) is an 18-month rehabilitation program for prisoners who are serving sentences for sex crimes. Currently, SOTP is offered at three TDCJ facilities. In fiscal year 2002, SOTP admitted 744 prisoners. The program has a capacity to serve 426 prisoners at one time. ${ }^{132}$ The program targets sex offenders within two years of their release date and consists of four phases of treatment: (1) in-prison therapy, (2) off-site work programs, (3) community-based transition programs, and (4) aftercare for offenders released to postrelease supervision (though few sex offenders are discharged with postrelease supervision requirements). ${ }^{133}$ For those prisoners who complete all program components, the program is extremely successful: CJPC reports that these prisoners have a 38 percent lower arrest rate and a 39 percent lower reincarceration rate than the comparison group. ${ }^{134}$ CJPC reports that approximately a quarter (22 percent in fiscal year 1997 and 25 percent in fiscal year 1999) complete the 18-month program. 


\section{FAITH-BASED INITIATIVE}

In 1997, the Prison Fellowship, a national Christian outreach organization, initiated the InnerChange Freedom Initiative (IFI), a faith-based intervention program. To prepare prisoners for reentry, IFI teaches academic, vocational, and life skills classes from a biblical and moral perspective. While participation is voluntary, the only prisoners who are eligible are those who (1) are within 18 to 24 months of release, (2) are returning to Harris County and other adjacent counties, (3) are functionally literate (educational achievement score above 6.0), (4) have no enemies at the facility, and (5) are willing to accept Christian teachings. The IFI program can serve up to 200 prisoners and served 153 prisoners in fiscal year 2002. A 2003 CJPC evaluation found that prisoners who completed the program's prerelease and postrelease components had a recidivism rate of 8 percent, substantially less than the comparison group's 20 percent recidivism rate; the study also found that 42 percent of participants complete the program. ${ }^{135}$ A preliminary evaluation of the InnerChange Freedom Initiative conducted by the University of Pennsylvania also noted that graduates of this program were 50 percent less likely to be rearrested than a matched comparison group and 60 percent less likely to be reincarcerated. ${ }^{136}$

\section{BEHAVIOR ADJUSTMENT PROGRAMS}

To prepare prisoners for reintegration, WSD also offers programs that teach social skills and community responsibility. Some examples of these programs are listed below; all of them are administered in TDCJ correctional facilities. ${ }^{137}$

\section{- Changing Habits and Achieving New Goals to} Empower Success (CHANGES). This 60-day Windham School District program teaches prisoners

Behavior Adjustment Programs

- Changing Habits and Achieving New Goals to Empower Success

- Cognitive Intervention

- Parenting within two years of release life skills for successful reintegration, including family and parenting skills, civic responsibilities, health skills, labor market skills, money management, and social skills. In 2002, 23,980 prisoners participated in the CHANGES program.

- Cognitive Intervention. This program, which was developed with assistance from the National Institute of Corrections and implemented in 60 of 114 Texas prisons, aims to build prisoners' problem-solving and social skills. This program is specifically designed for and targets prisoners with disciplinary issues and served 10,401 prisoners in fiscal year 2002.

- Parenting. This program offers confinees classes to help them develop healthy family relationships using a curriculum developed by Family Forward $\AA$, a statewide organization whose mission is to strengthen families and promote family stability. ${ }^{138}$ 
State jail facilities that offer WSD classes also provide confinees the opportunity to participate in parenting classes. In fiscal year 2003, 4,377 prisoners participated in parenting classes.

\section{WOMEN'S PROGRAMS}

As of August 31, 2002, 7 percent of the TDCJ prison and state jail population were women. ${ }^{139}$ TDCJ provides programs exclusively for women incarcerated in TDCJ facilities to address the issues unique to this population.

- Love Me Tender. This program, which the University of Texas Medical Branch administers, aims to increase bonding time for newborns and

\section{Women's Programs}

- Love Me Tender

- Girl Scouts Behind Bars

- Plane State Jail WrapAround Program

- The Empowerment Project their mothers. For those not in the program, healthy mothers and their newborns are generally separated within six hours of birth.

- Girl Scouts Behind Bars. TDCJ's Programs and Services Division also coordinates this program in two facilities within the TDCJ-Hilltop and Plane State Jail. The program's main goal is to allow mothers and their children to remain in contact during incarceration. Regular Girl Scout meetings held in the community are combined with meetings in prison.

- Plane State Jail Wrap-Around Program. TDCJ's Programs and Services Division also coordinates the Plane State Jail Wrap-Around Program, which offers transitional services to female confinees returning to Harris County. The division has partnered with various agencies in Houston committed to meeting the needs of these women, particularly in the areas of education, job/vocational training, mental health issues, substance abuse issues, housing needs (several halfway houses offer placement), and access to health care.

- The Empowerment Project. Launched in fiscal year 2003 at the Woodman State Jail, this program is a pilot program for women who have been sexually abused or were victims of domestic violence. Participants receive counseling and education during their incarceration and referrals to groups within their community upon release. The Austin-based Texas Council of Family Violence administers this program. 



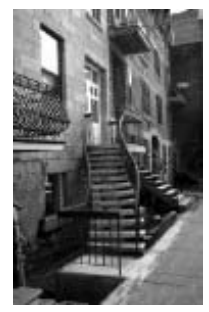

\section{H A P T E R 4}

\section{How Are Texas Prisoners Released?}

$\mathrm{T}$ he growth in the TDCJ prison population over the past 14 years has led to an increase in the number of prisoner releases. ${ }^{140}$ As figure 4.1 illustrates, in 2002 TDCJ prisons and state jails released 58,949 prisoners-73 percent more than the number of prisoners released in $1988(34,410)$. These prisoners, like those across the nation, are released either through a discretionary or a nondiscretionary process. With nondiscretionary release, state statutes and the prisoner's court-ordered sentence determine the prisoner's release date at the time of sentencing. With discretionary release, a parole board, judge, or other authority reviews the prisoner's case, once the prisoner has served a statutorily required portion of his sentence, to decide whether to release the prisoner earlier than the date specified by the court. ${ }^{141}$

Figure 4.1. TDCJ releases, FY 1988 to FY 2002

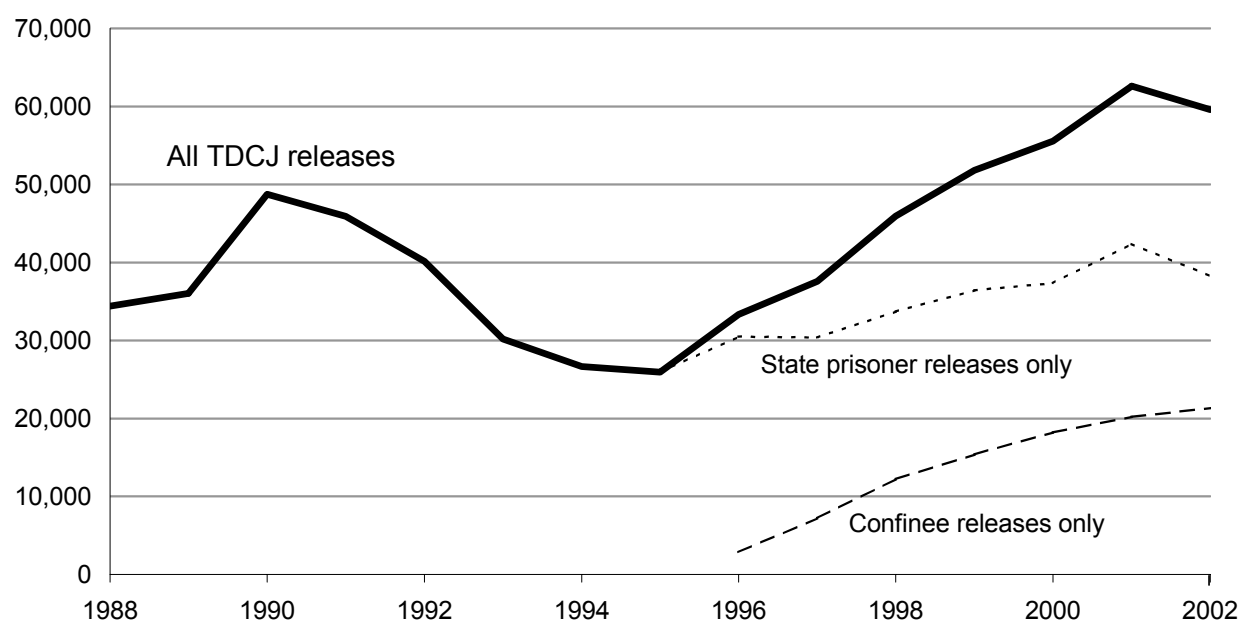

Source: Urban Institute analysis of Criminal Justice Policy Council data. 
Figure 4.2. TDCJ discretionary and nondiscretionary releases as a percentage of all releases, FY 1988 to FY 2002

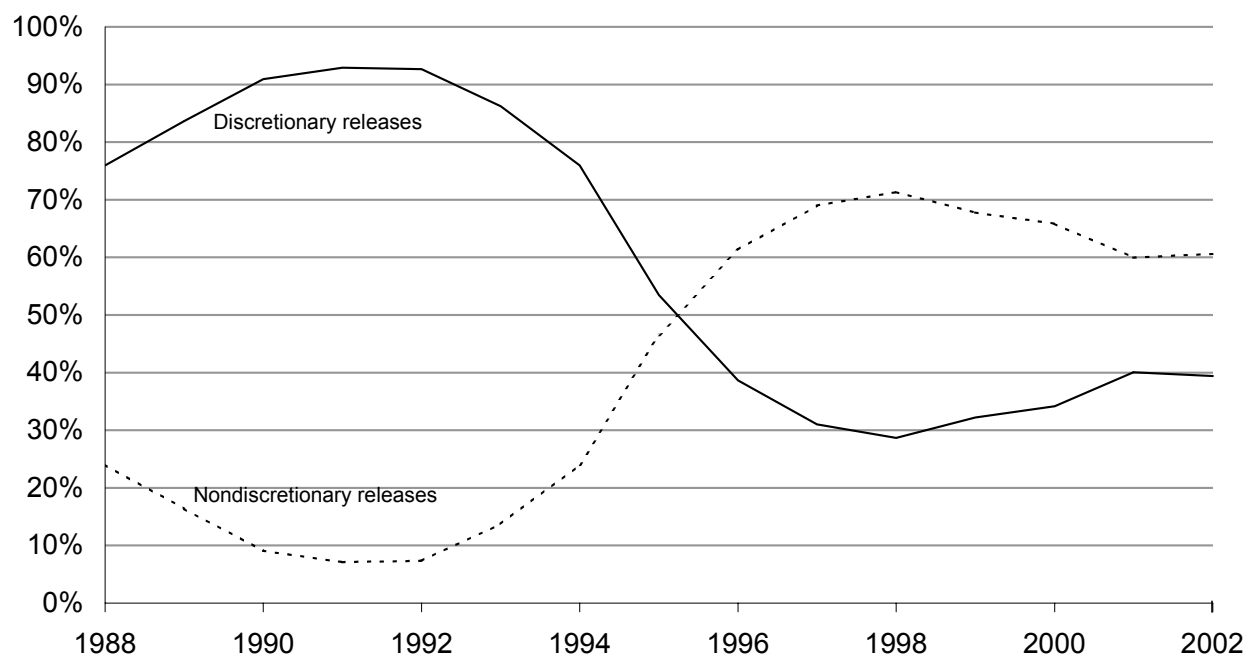

Source: Urban Institute analysis of Criminal Justice Policy Council data.

Between 1988 and 2002, the percentage of TDCJ releases approved for discretionary release dropped from 75 to 38 percent. The proportion of discretionary releases began to fall after 1992 (figure 4.2) when, most notably, parole approval rates were falling dramatically (refer back to figure 1.15). The creation of the state jail felon category in 1994 also contributed to the decline in discretionary releases since those prisoners are ineligible for the most common forms of discretionary release (parole and discretionary mandatory supervision). Thus, while the majority (60 percent) of state prisoners are released through the approval of a discretionary body, only 1 percent of confinees are released through discretionary mechanisms (figure 4.3 ). ${ }^{142}$

Figure 4.3. State prisoner and confinee discretionary releases as a percentage of all releases, FY 1988 to FY 2002

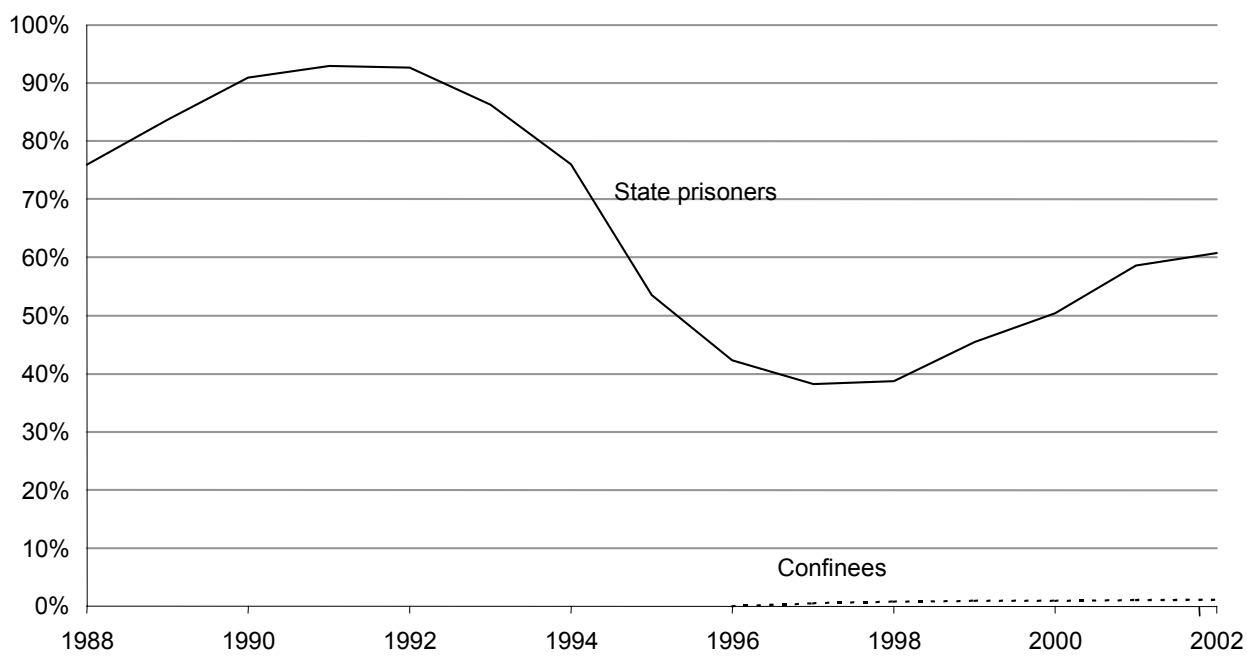

Source: Urban Institute analysis of Criminal Justice Policy Council data. 
Accordingly, nondiscretionary releases accounted for more than half (62 percent) of all TDCJ releases in 2002, up from 25 percent in 1988. These prisoners completed their entire sentence length in prison or state jail, many without review by a parole board or a judge. The use of discretionary release has important implications for reentry. Under discretionary release, a panel reviews a prisoner's case during his incarceration; they consider his institutional conduct, criminal history, and postrelease plans, such as living arrangements and employment. ${ }^{143}$ This review can provide an important incentive for prisoners to comply with institutional rules, participate in programs, and develop a strategy for reentry. Also, while some nondiscretionary release mechanisms do not entail postrelease supervision requirements, discretionary release always entails these requirements. Figure 4.4 summarizes the key characteristics of each release mechanism.

\section{A CLOSER LOOK AT DISCRETIONARY RELEASE}

TDCJ prisoners can be released through one of three discretionary means: parole, discretionary mandatory supervision (DMS), and shock probation. Prisoners released through parole and DMS are subject to postrelease supervision under parole. Prisoners released through shock probation are subject to postrelease supervision under probation. A full description of shock probation is not included in the text below because it applies to so few prisoners (approximately 1 percent of all releases in 2002). However, shock probation is counted in this chapter's graphs to provide a complete picture of discretionary release practices.

All state prisoners except those incarcerated for certain violent crimes, particularly aggravated violent crimes such as first- or second-degree assaults, are eligible for discretionary release through any of these mechanisms. In contrast,

\section{DMS vs. RMS}

Prisoners sentenced before September 1, 1996, may be eligible for release to mandatory supervision (RMS). RMSeligible prisoners are released automatically once their time served and good-time credits sum to their sentence length. Prisoners sentenced on or after September 1, 1996, are ineligible for RMS but may be eligible for discretionary mandatory supervision (DMS). To be released through DMS, however, the Board of Pardons and Paroles must review a prisoner's case and award approval. Approved prisoners are released to DMS once their time served and good-time credits sum to their sentence length.

confinees are ineligible for either parole or DMS. Accordingly, as the confinee population has grown (since first implemented in 1994), discretionary releases have fallen. 
Figure 4.4. Summary of release types

\begin{tabular}{|c|c|c|c|c|c|c|}
\hline Type of release & Authority & $\begin{array}{l}\text { Time of } \\
\text { decision }\end{array}$ & $\begin{array}{c}\text { Eligible } \\
\text { population }\end{array}$ & $\begin{array}{l}\text { Postrelease } \\
\text { supervision }\end{array}$ & $\begin{array}{c}\text { Percent of } \\
\text { releases in } \\
1988\end{array}$ & $\begin{array}{c}\text { Percent of } \\
\text { releases in } \\
2002\end{array}$ \\
\hline \multicolumn{7}{|l|}{ Discretionary } \\
\hline Parole & $\begin{array}{l}\text { Board of } \\
\text { Pardons and } \\
\text { Paroles }\end{array}$ & $\begin{array}{l}\text { During } \\
\text { incarceration }\end{array}$ & $\begin{array}{l}\text { State } \\
\text { prisoners }\end{array}$ & Parole & 75 & 23 \\
\hline $\begin{array}{l}\text { Discretionary } \\
\text { mandatory } \\
\text { supervision (DMS) }\end{array}$ & $\begin{array}{l}\text { Board of } \\
\text { Pardons and } \\
\text { Paroles }\end{array}$ & $\begin{array}{l}\text { During } \\
\text { incarceration }\end{array}$ & $\begin{array}{l}\text { State } \\
\text { prisoners }\end{array}$ & Parole & $\begin{array}{l}\text { Did not yet } \\
\text { exist }\end{array}$ & 15 \\
\hline Shock probation & Judge & $\begin{array}{l}\text { During } \\
\text { incarceration }\end{array}$ & $\begin{array}{l}\text { State } \\
\text { prisoners; } \\
\text { confinees }\end{array}$ & Probation & 1.5 (est.) & 1 (est.) \\
\hline \multicolumn{7}{|l|}{ Nondiscretionary } \\
\hline Direct discharge & Judge & $\begin{array}{l}\text { Set at } \\
\text { sentencing }\end{array}$ & $\begin{array}{l}\text { State } \\
\text { prisoners; } \\
\text { confinees }\end{array}$ & None & 0.4 & 45 \\
\hline $\begin{array}{l}\text { Release to } \\
\text { mandatory } \\
\text { supervision (RMS) }\end{array}$ & $\begin{array}{l}\text { Board of } \\
\text { Pardons and } \\
\text { Paroles }\end{array}$ & $\begin{array}{l}\text { Set at } \\
\text { sentencing }\end{array}$ & $\begin{array}{l}\text { State } \\
\text { prisoners }\end{array}$ & Parole & 23 & 14 \\
\hline & & & & & & 1 (est.) \\
\hline $\begin{array}{l}\text { Split } \\
\text { sentence/probation } \\
\text { modification }\end{array}$ & Judge & $\begin{array}{l}\text { Set at } \\
\text { sentencing }\end{array}$ & $\begin{array}{l}\text { State } \\
\text { prisoners; } \\
\text { confinees }\end{array}$ & Probation & Not Available & $\begin{array}{l}\text { Data not } \\
\text { available for } \\
\text { state } \\
\text { prisoners }\end{array}$ \\
\hline Boot camp & Judge & $\begin{array}{l}\text { Set at } \\
\text { sentencing }\end{array}$ & $\begin{array}{l}\text { State } \\
\text { prisoners }\end{array}$ & Probation & $\begin{array}{l}\text { Did not yet } \\
\text { exist }\end{array}$ & 1 (est.) \\
\hline
\end{tabular}

\section{Parole}

The Texas Board of Pardons and Paroles can expedite a state prisoner's release date by authorizing parole (confinees and prisoners sentenced to death are ineligible for parole). Parole allows a state prisoner to serve the remainder of his sentence in the community under supervision while complying with specified Ineligible for Parole

- Confinees

- Prisoners sentenced to death $^{144}$ conditions of release. ${ }^{145}$ A prisoner is eligible for parole once his time served and credits for good behavior sum to a certain percentage of his sentence as specified in Texas statute. ${ }^{146}$ This percentage increases for more serious offenses, and ranges from 25 to 50 percent. ${ }^{147}$

State prisoners are informed of their parole-eligibility date upon admission to TDCJ. Several months prior to a state prisoner's parole-eligibility date, a parole officer meets with the state prisoner to review his or her case. The officer records a summary of the case, including his or her criminal and social background, physical and mental health, and institutional behavior. By the prisoner's parole-eligibility date, the Board of Pardons and Paroles reviews the case summary and approves parole if the prisoner is likely to comply with release conditions and is not likely to pose a threat to public safety. Prior to making this decision, board members can request that the prisoner appear before them to answer questions, but they rarely do so given the volume of 
prisoners considered for parole and discretionary mandatory supervision (nearly 8,000 per month in 2002). ${ }^{148}$

The Board sets the prisoner's release date and conditions of release, discussed further in the next chapter, when they approve parole. ${ }^{149}$ The Board can release the prisoner immediately to parole, set a later parole-release date, or require that the prisoner first participate in an institutional rehabilitation program for 3 to 18 months. At the time of release, TDCJ provides parolees with a copy of their release conditions, including the name of their parole officer and the time and location of their first meeting with the officer. At the initial meeting, the parole officer reviews parolees' release conditions with them. Parolees serve the remainder of their sentence (the sentence length minus the time served in prison) in the community under parole supervision. For prisoners denied parole, the Board reviews their cases within the next five years.

The number and share of prisoners released to parole has fallen dramatically over the past 14 years. In 1988, 28,090 prisoners were paroled (75 percent of all releases) and, in 2002, 15,426 prisoners were paroled (23 percent of all releases). ${ }^{150}$ See chapter 1 for a discussion of potential explanations for this trend.

In 2002, members of the Board of Pardons and Paroles were only slightly more likely to parole prisoners incarcerated for nonviolent offenses than those incarcerated for violent offenses. The Criminal Justice Policy Council reports the following approval rates for each offense type:

- Nonviolent

- Aggravated violent

- Nonaggravated violent

- Nonaggravated sex offense

- Aggravated sex offense
30 percent $(11,187$ of 37,841$)$

22 percent $(1,586$ of 7,130$)$

21 percent $(2,186$ of 10,262$)$

8 percent $(201$ of 2,496$)$

3 percent $(86$ of 3,146$)$

Notably, although prisoners incarcerated for nonviolent crimes were only slightly more likely to be approved for parole than other prisoners, they still served a significantly shorter portion of their sentence on average ( 31 percent compared to between 50 and 60 percent for most other offense types).

\section{Discretionary Mandatory Supervision}

The Board of Pardons and Paroles can also expedite state prisoners' release by authorizing discretionary mandatory supervision (DMS) release. DMS allows eligible state prisoners to be released when their time served and their good-time credits sum to their sentence length. ${ }^{151}$ If approved, state prisoners then serve the remainder of their sentence in the community under parole supervision. DMS

Ineligible for DMS

- Confinees

- State prisoners incarcerated for some aggravated or violent crimes

- State prisoners sentenced before September 1, 1996

was implemented in 1996; prior to this time, all releases to mandatory supervision were automatic (nondiscretionary). 
Fewer TDCJ prisoners are eligible for DMS than for parole. ${ }^{152}$ As with parole, no confinees or death-sentenced state prisoners are eligible for DMS. Unlike parole, however, state prisoners who have committed particular aggravated or violent offenses (such as any crime involving a deadly weapon, first-degree burglary, and first- and second-degree aggravated assaults) are ineligible for DMS, as are state prisoners sentenced prior to September 1, $1996 .{ }^{153}$ The DMS review process is entirely paper-based, meaning eligible prisoners never appear before the Board for hearings. TDCJ forwards prisoners' case files to the Board, and the Board notifies TDCJ of its decision. Although the Board can require DMS-approved state prisoners to participate in an institutional program before approving DMS release, they rarely do so. ${ }^{154}$ The Board reviews denied cases within one year of their initial decision.

The Board sets the conditions of release for those prisoners approved for DMS, and the prisoner is given a printed copy of these conditions at release. This document specifies all release conditions, the name of their parole officer, and the time and location of their first meeting with the officer. At this meeting, the parole officer reviews their release conditions with them. The DMS releasee is supervised under parole for the remainder of his sentence (the sentence length minus the time served in prison).

The share of prisoners released to DMS has grown between 1998 (when data are first available) and 2002. Three percent of all TDCJ prisoners released in 1988 were released through DMS; by 2002, 15 percent were released through DMS. As more state prisoners have become eligible for DMS release (i.e., they were

Nearly half (49 percent) of nonviolent offenders considered for parole and DMS were not approved. sentenced on or after September 1, 1996), the proportion of TDCJ prisoners released through DMS has increased. As this growth continues, discretionary releases will, in turn, increase as they have since 1998 when DMS data first became available and were added into the discretionary release pool. ${ }^{155}$

DMS approval rates are nearly double parole approval rates. From 1998 (when data are first available) to 2002, the approval rate for DMS considerations remained between 46 and 61 percent annually. Compared to parole, the Board has significantly higher DMS approval rates for nonviolent offenders than for violent offenders. The following is a summary of the 2002 approval rates for each offense type:

- Nonviolent

- Aggravated violent

- Nonaggravated violent

- Nonaggravated sex offense

- Aggravated sex offense
61 percent $(8,272$ of 13,574$)$

0 percent $(0$ of 9$)$

37 percent $(646$ of 1,754$)$

14 percent (24 of 169)

4 percent ( 3 of 71 )

Nonviolent state prisoners approved for DMS served half (49 percent) of their sentences while other state prisoners approved for DMS served between 53 and 66 percent of their sentences. 


\section{A CLOSER LOOK AT NONDISCRETIONARY RELEASE}

All TDCJ prisoners not eligible or not approved for discretionary release are released nondiscretionarily through one of five means: direct discharge, release to mandatory supervision, split sentence, probation modification, or boot camp. Some state prisoners (see below for further detail) and all confinees are ineligible for mandatory supervision and boot camps. All but those prisoners released through direct discharge are subject to postrelease supervision. A full description of split sentence, probation modification, and boot camp is not included in this discussion because they apply to so few prisoners (approximately 2 percent of all releases). However, they are counted in this chapter's graphs to capture nondiscretionary release trends. ${ }^{156}$ A short overview of direct discharge and release to mandatory supervision follows.

\section{Direct Discharge}

Prisoners released through direct discharge serve the full term of their court-ordered sentence-without reductions in their term for good behavior - and are released to the community without supervision. Over the past 14 years, direct discharges rose as a proportion of all TDCJ releases: in 1988, 0.4 percent of all TDCJ prisoners were direct

\section{Eligibility for Direct Discharge}

All prisoners eligible for release are eligible for direct discharge. discharges, while nearly half (45 percent) of all releases were direct discharges in 2002 . The vast majority of direct discharges are confinees. Nearly 100 percent of confinees are released this way, compared with 16 percent of state prisoners (2002). ${ }^{157}$

\section{Release to Mandatory Supervision}

All state prisoners who were sentenced before September 1, 1996, but not sentenced to death are released automatically through release to mandatory supervision (RMS) when their time served plus their good-time credits sum to their sentence length. State prisoners receive good-time credits through program participation and by avoiding disciplinary infractions. Many state prisoners receive one day of Ineligible for RMS

- State prisoners sentenced on or after September 1 , 1996

- Confinees good-time credit for each day served, but the total credits received can be adjusted on a case-bycase basis. The Board of Pardons and Paroles sets the release conditions prior to the prisoner's release under mandatory supervision, and the prisoner receives a copy of these conditions at release. The mandatory supervision releasee is supervised under parole for the remainder of his sentence, which equals the sentence length minus the time served in prison.

Mandatory supervision releases have shrunk over the past 14 years. In 1988, 23 percent of all TDCJ prisoners were released through mandatory supervision; by 2002, just 14 percent were. In the future, the number of mandatory supervision releases will continue to decrease as the number of prisoners sentenced after September 1, 1996, increases. 



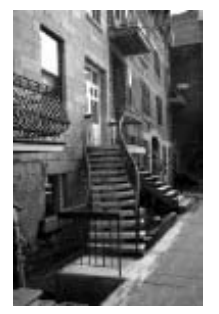

\section{H A P T R 5}

\section{How Are Texas Prisoners Supervised upon Release?}

$\mathrm{I}$

n 2002, slightly more than half (55 percent) of released prisoners were subject to some period of postrelease supervision under either parole or probation, a drop from 99.6 percent in 1988 and substantially lower than the national average of 77 percent (figure 5.1). ${ }^{158}$ In 2002, almost half (45 percent) of TDCJ prisoners were released following the expiration of their sentences and were not subject to any release conditions or any form of postrelease supervision. These prisoners were under no legal obligation to abide by release conditions, such as having a job,

\section{Note on Language}

In this chapter, prisoners released through mandatory supervision or discretionary mandatory supervision are referred to as parolees because they are supervised by the Parole Division following their release and are subject to the same requirements as parolees. participating in drug or alcohol treatment, or having prearranged housing plans.

When disaggregating post-release supervision trends by prisoner type, significant differences emerge. Although the percentage of state prisoners released to supervision has declined over the past 14 years, the overwhelming majority of state prisoners continue to be released to supervision. In 1988, 99.6 percent of state prisoners were released to supervision; 84

Figure 5.1. Percentage of all TDCJ releases released to supervision, FY 1988 to FY 2002

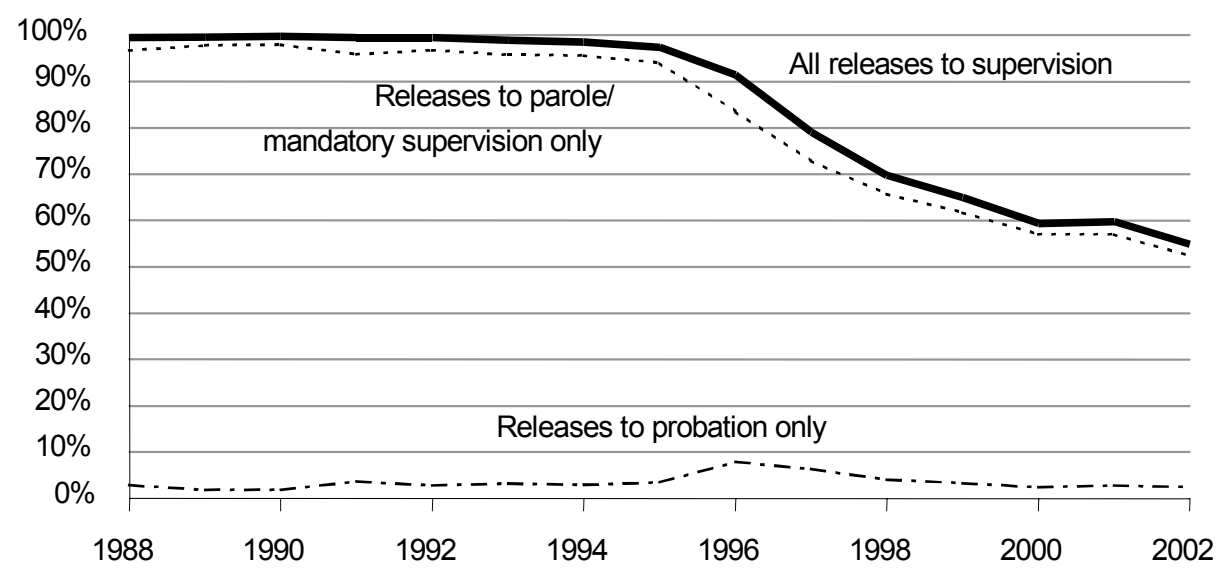


Figure 5.2. Percentage of all released state prisoners and confinees released to supervision, FY 1988 to FY 2002

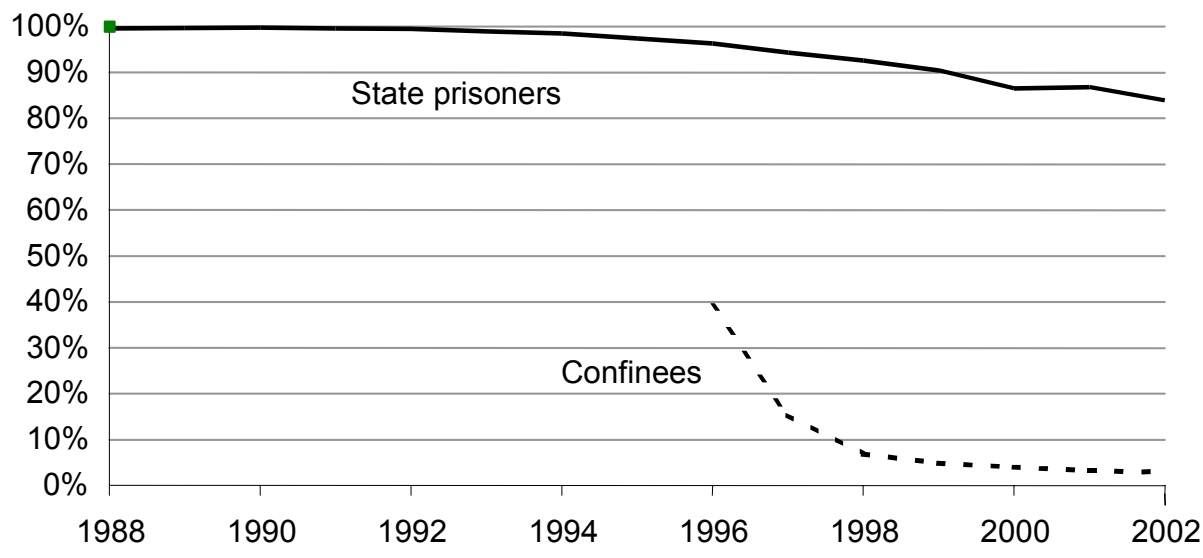

Source: Urban Institute analysis of the Criminal Justice Policy Council data.

percent were released to supervision in 2002 (figure 5.2). At the same time, the percentage of confinees released to supervision has decreased dramatically since fiscal year 1996, when data are first available. In 1996, 39 percent of all confinees were released to supervision; by 2002, 3 percent were released to supervision. The primary reason for this decline is that judges began to administer fewer sentences that required probation supervision following release. ${ }^{159}$

The total number of TDCJ prisoners released to parole supervision as a percentage of all TDCJ releases has dropped substantially over the past 14 years: in 1988, 97 percent $(33,267)$ of all TDCJ prisoners were released to parole supervision; by 2002, 52 percent $(31,193)$ were released as such. ${ }^{160}$ As a result, the number of people under the Parole Division's supervision grew more slowly than the number of TDCJ releases grew-by 50 percent compared to 73 percent.

Prisoners can also be released to supervision via probation. The total percentage of all TDCJ prisoners released to probation was, on average, 3.8 percent between 1988 and 2002. Because so few prisoners are released to probation, the rest of this section focuses on parole.

\section{CASELOADS}

Texas's active parole population increased most dramatically from 1988 to 2002 (by 50 percent, from 52,047 to 78,160 ) and then largely stabilized (figure 5.3). ${ }^{161}$ Parole officers' caseloads dropped dramatically during the past 12 years. In 1990, the average caseload was 124 parolees; but by April 2002, the average was 64 regular supervision parolees. ${ }^{162}$ 
Figure 5.3. Active parole population in Texas, FY 1988 to FY 2002

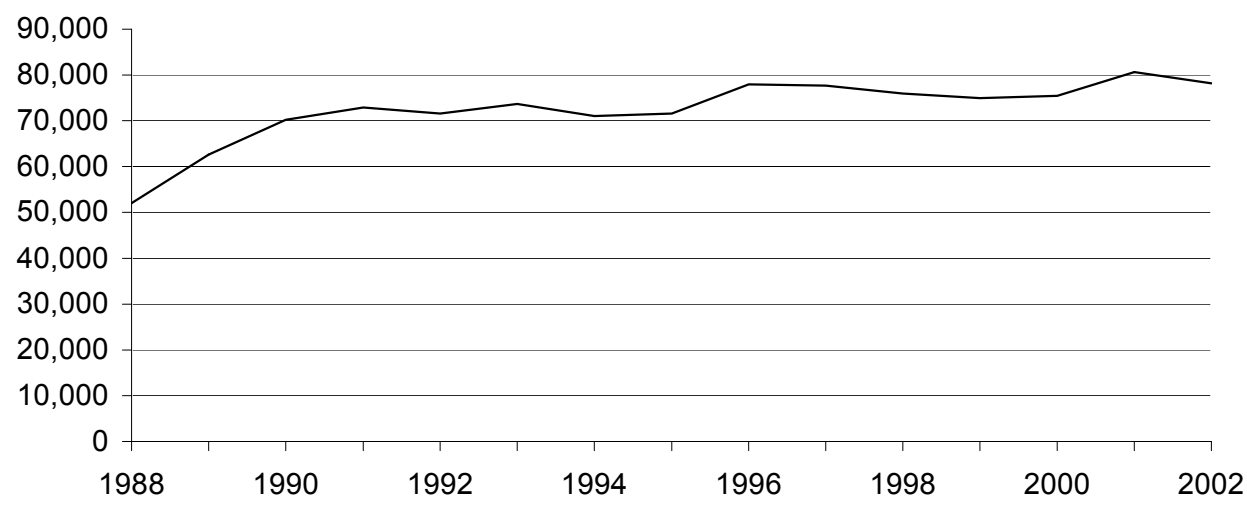

Source: Urban Institute analysis of the Criminal Justice Policy Council data.

\section{CONDITIONS OF RELEASE}

Postrelease supervision always involves a set of release conditions-requirements that the prisoner is obligated to fulfill as a condition of his or her release to the community. Some release conditions are standard components of supervision while others are tailored to address a particular offender's needs. Failing to fulfill all release conditions can, at a minimum, lead to sanctions and can, at a maximum, lead to supervision revocation and, consequently, reincarceration.

The Board of Pardons and Paroles sets the conditions of release for prisoners released through parole, release to mandatory supervision, or discretionary mandatory supervision; and TDCJ's Parole Division supervises releasees through district parole officers. These groups are subject to similar rules, regulations, and release conditions after release. Consequently, this chapter refers to releases to mandatory supervision and discretionary mandatory supervision releases as parolees. A typical parolee is required to (1) report to the supervising parole officer at specified times and locations, (2) comply with the law, (3) secure the supervising parole officer's written permission before changing residence, (4) avoid owning or distributing a firearm, (5) avoid contact with persons of criminal background, (6) obtain the parole officer's written permission to act as an "informer" for any law enforcement agency, (7) pay monthly administrative and supervision fees to the Parole Division, (8) pay any outstanding legal fees, and (9) comply with any special conditions imposed by board members. Parolees are given $\$ 50$ and a bus ticket at the time of their release and, as an incentive for contacting the supervising parole officer, are awarded another $\$ 50$ once they report to their parole officers. ${ }^{163}$ Special conditions of release may include residency in community-based housing, sex offender stipulations, drug testing, program participation, counseling, or payment of restitution. Programs may include substance abuse treatment, sex offender treatment, education, cognitive restructuring, anger management, family and children enhancement services, and employment training and services. 
The special condition requiring the state prisoner to reside in supervised communitybased housing provides an extra period of transition for state prisoners identified as posing a higher risk and/or possessing greater needs than the average releasee. These programs allow the state prisoner to transition back into freedom with more intense supervision and assistance within a structured environment. Community-based housing can provide the state prisoner the opportunity to find employment and secure housing before being released directly to the street. Toward this end, the Board may require the prisoner to reside in either a pre-parole transfer facility (PPT) or a halfway house.

TDCJ administers PPTs, which are community-based, prerelease residential programs that include counseling, education classes, vocational training, and other programs and services. As of August 31,2002, these facilities had a maximum capacity of 2,800 and were approximately three-quarters full (figure 5.4). ${ }^{164}$ Of the 31,193 prisoners released from TDCJ custody to parole in 2002, 4,665 (15 percent) were released from PPTs. ${ }^{165}$ TDCJ's Parole Division also manages halfway houses, which are community-based programs that focus on reintegrating parolees into the community prior to their release from TDCJ custody or upon special request by a parole officer. At the end of fiscal year 2002, the Parole Division held 1,199 beds in nine halfway houses under contract. ${ }^{166}$ And, in fiscal year 2002, 4,719 parolees were released from halfway houses. ${ }^{167}$

Figure 5.4. Texas parole facilities, capacity, and usage, FY 2002

\begin{tabular}{lrr}
\hline \multicolumn{1}{c}{ Facility type } & Capacity & \multicolumn{2}{c}{ Total served } \\
\hline Pre-parole transfer facility & 2,800 & 4,665 \\
Halfway house & 1,199 & 4,719 \\
Total & $\mathbf{3 , 9 9 9}$ & $\mathbf{9 , 3 8 4}$ \\
\hline
\end{tabular}

Source: Texas Department of Criminal Justice, Parole Division.

In fulfilling their release conditions, parolees paid nearly $\$ 9$ million in fees to the Parole Division in fiscal year 2003. ${ }^{168}$ Three-quarters of these funds were used toward the cost of supervision, one-quarter was applied to the Crime Victims' Compensation Fund, and less than 1 percent was used for the Sexual Assault Program Collections. On average, parolees are required to pay $\$ 10$ per month toward the cost of supervision, crime victims' compensation, and sexual assault programs. ${ }^{169}$

\section{INTENSITY OF SUPERVISION}

The intensity of a prisoner's postrelease supervision depends on the estimated risk that the prisoner poses to public safety given his or her background, reentry challenges, and other individual characteristics. In short, the greater the risk an offender poses, the greater the intensity of supervision the prisoner receives. To determine a prisoner's risk, parole officers use standardized assessment tools. ${ }^{170}$ According to the parolee's risk level, the Board of Pardons and Paroles assigns the parolee to one of seven levels of supervision: quarterly reporting, minimum, 
medium, maximum, intensive, super-intensive, or specialized. ${ }^{171}$ For all levels of supervision except quarterly reporting, the parole officer must contact a person with knowledge of the parolee and confirm the parolee's employment, compliance with specified release conditions, residence within 30 days of a move, and program participation. The minimum level of supervision requires that the parolee contact the parole officer once a month, and the maximum requires that he or she do so four times a month. Most parolees are subject to the medium level of supervision, which requires that the parolee meet the parole officer in the office once each month. It also requires that the parole officer meet the parolee at home or in the community once every two months, validate employment and counseling once per month, and validate the parolee's new address within 30 days of any move.

\section{REVOCATION}

While postrelease supervision may aid in the reintegration process, the increased surveillance raises the likelihood that ex-prisoners will be reincarcerated for either committing a new crime (a new crime violation) or failing to comply with their release conditions (a technical violation). Between 1988 and 1993, a growing parole population and a rising parole revocation rate led revocations in Texas to more than double, rising from 11,084 to 24,250. After 1993, however, the parole population and revocation rates fell until sentences to prison for parole revocations had dropped to 10,666 in 2002 , slightly less than the total in 1988. In 1999, parole revocations accounted for a relatively small proportion (18 percent) of admissions in Texas when compared with the national average of 35 percent (figure 5.5). ${ }^{172}$ In 1999, 20 percent of parole and mandatory supervision revocations were due to technical violations, and the remainder was due to new crimes. Parole Division staff report that typical technical violations involve failure to report to the parole officer and failure to obtain permission to change residences.

Through the revocation process, if a parolee fails to comply with minor rules, the Board can choose to hold a hearing or administer a minor sanction, such as writing a letter of admonition to the parolee. If a parolee fails to comply with major requirements or commits a new

Figure 5.5. Parole and mandatory supervision revocations as a percentage of all TDCJ admissions, FY 1988 to FY 2002

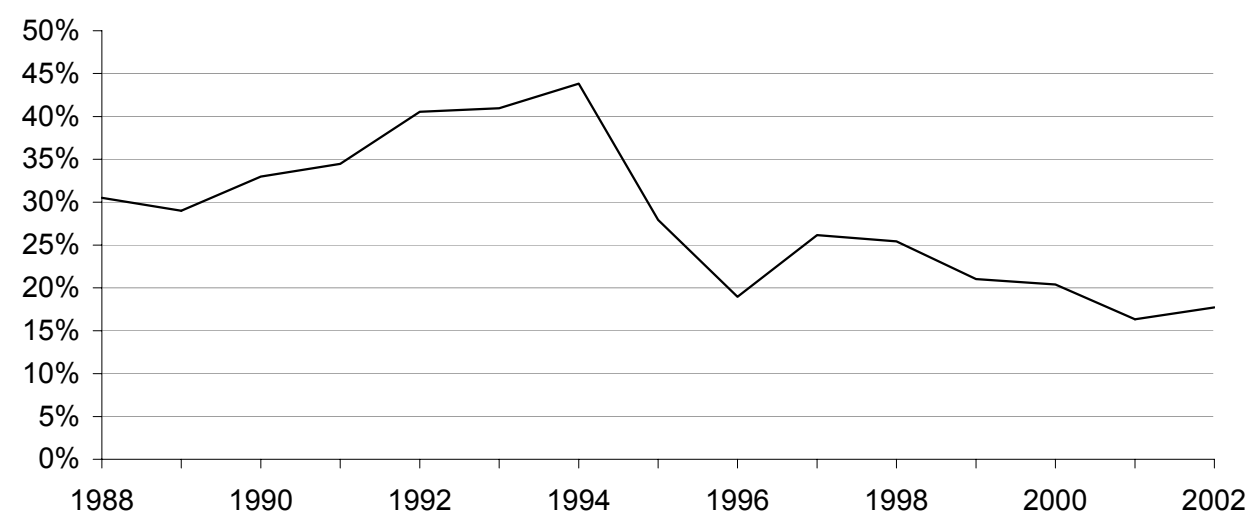

Source: Urban Institute analysis of the TDCJ and Criminal Justice Policy Council data. 
offense, the Board can have local law enforcement issue a warrant for his or her arrest (referred to in Texas as a "blue warrant"). ${ }^{173}$ Following arrest, the ex-prisoner is held in county jail until interviewed by a parole officer. Prior to 1998, a parolee arrested under a blue warrant could be held in the county jail for up to seven months prior to the disposition of his or her case. In 1998, legislation took effect that reduced the maximum time that the parolee could remain in county jail to two months. ${ }^{174}$ Following implementation of this legislation, CJPC found that the number of parolees with blue warrants held in county jails dropped by 41 percent, from approximately 3,700 in the month immediately preceding implementation of this change to approximately 2,200 seven months after its implementation.

In fiscal year 1999, CJPC found that 26 percent (or 27,238) of all parolees had revocation hearings. ${ }^{175}$ In most (66 percent) hearings, the Board of Pardons and Paroles either found the parolee or mandatory supervision releasee not guilty or rendered punishments that did not involve revocation.

When parole is revoked for a new crime or a technical offense, the parolee returns to state prison and serves the remainder of his or her sentence. The time served under community supervision does not count toward the prisoner's sentence unless he or she (1) meets the qualifications described in House Bill 1649 (prisoners who committed serious violent offenses are often ineligible) and (2) has served at least half of the sentence (in prison and under supervision) prior to revocation. ${ }^{176}$ The Board can also choose to allow the violator to remain in the community under supervision or transfer him to either an Intermediate Sanction Facility (ISF) or a Substance Abuse Felony Punishment facility (SAFP). An ISF is a correctional facility in which violators are incarcerated for a brief time (up to 90 days), and participants may take part in community service restitution, education, and life skills/cognitive training programs. SAFPs are in-prison programs for which participants receive substance abuse treatment and counseling. As of October 29, 2003, the total number of ISF and SAFP beds available to parolees was 2,117; 1,951 beds were occupied. ${ }^{177}$ 


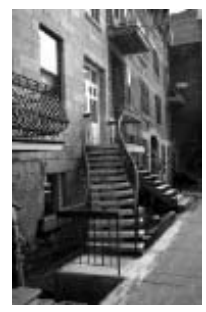

\section{H A P T E R 6 Where Do Released Prisoners Go?}

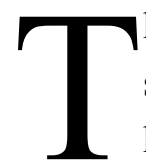

he community context of prisoner reentry can have an important influence on postrelease success or failure. It stands to reason that ex-prisoners returning to neighborhoods with high unemployment rates, limited affordable housing options, and few services may be more likely to relapse and recidivate. To understand the community context of reentry in Texas, it is first necessary to examine the geographic distribution of released prisoners. This chapter presents findings from a geographic analysis of ex-prisoners and examines this reentry distribution in relation to the socioeconomic characteristics of areas with the highest percentage of released prisoners in 2001 and the characteristics of prisoners returning to each area.

In calendar year 2001, 55,183 men and women were released from TDCJ to the community. ${ }^{178}$ Virtually all (99 percent) of these prisoners returned to Texas neighborhoods, and over half (58 percent) returned to 5 of Texas's 254 counties (Harris, Dallas, Tarrant, Bexar, and Travis) (figures 6.1 and 6.2). None of the remaining 249 counties in Texas received more than 2 percent of returning prisoners. Slightly more than one-quarter (26 percent, or 14,129) returned to Harris County, which includes Houston. The next largest share $(15$ percent, or 7,971$)$ returned to Dallas County, which encompasses the city of Dallas. Close to 8 percent $(4,097)$ of released prisoners returned to Tarrant County, which comprises Fort Worth, and approximately 6 percent $(3,156)$ returned to Bexar County, which includes San Antonio. Finally, Travis County, which includes Austin, received 4 percent (2,342) of returning prisoners. The geographic distribution of prisoners released to Houston, the city to which the greatest share of prisoners return, is further discussed in the next chapter.

Figure 6.1. Number and rate of prisoner releasees to Texas by county, 2001

Number of Rate per

\begin{tabular}{lcc} 
County & returning prisoners & 1,000 residents \\
\hline Harris County & 14,129 & 4.2 \\
Dallas County & 7,971 & 3.6 \\
Tarrant County & 4,097 & 2.8 \\
Bexar County & 3,156 & 2.3 \\
Travis County & 2,342 & 2.9 \\
& & \\
Statewide Rate & 55,183 & 2.5 \\
\hline
\end{tabular}

Source: Urban Institute analysis of 2001 TDCJ data and U.S. Census Bureau Data. 
The geographic data revealed distinct trends of the characteristics of the prisoners returning to each of these five counties. For example, more than half ( 58 percent) of prisoners returning to Dallas County had been incarcerated for drug offenses, approximately one and a half times higher than the statewide average of 39 percent. And nearly two-thirds (62 percent) of prisoners returning to Bexar County had been incarcerated for violent offenses, over three and a half times higher than the statewide average of 17 percent. Also, the percentage of female prisoners released to Dallas County (26 percent) was nearly double the statewide average of 14 percent.

Although county information is available for 99 percent of all Texas releasees, zip code information is only available for prisoners released to parole or mandatory supervision (42 percent of all Texas releasees). These prisoners are referred to as "supervised releasees" in the text. ${ }^{179}$ For each county except Harris County, the greatest share of ex-prisoners return to the zip code where the county's halfway house for supervised releasees is located. For Harris County, the zip code receiving the second largest share of ex-prisoners is the zip code where Harris County's halfway house for supervised releasees is situated. Notably, the impact of prisoner reentry on communities with halfway houses may be different from those that receive ex-prisoners returning to the community at large. Prisoners living in halfway houses, for example, receive a greater level of supervision, structure, and support in their return. Also, prisoners in halfway houses may leave the community once released from the halfway house, relocating to some other area of the city. The following section notes the counties' zip codes with halfway houses and highlights differences between counties. 
Figure 6.2. Percentage of prisoner releasees to Texas by county, 2001

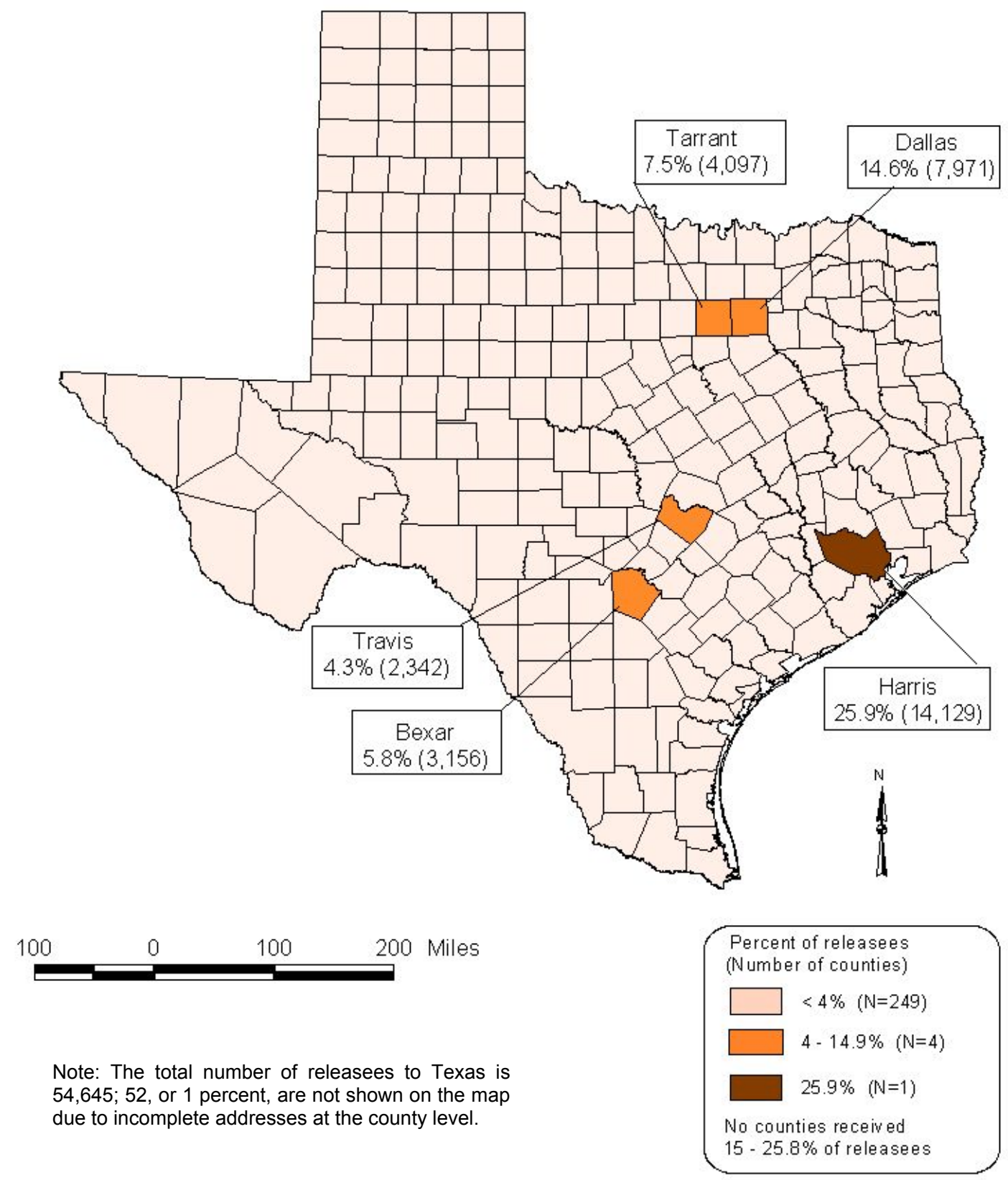

Source: Urban Institute analysis of 2001 TDCJ data. 


\section{PRISONER REENTRY IN DALLAS COUNTY}

Dallas County is the second most populous county in the state, with more than two million residents. The median household income in Dallas County is $\$ 43,324,9$ percent higher than the statewide median household income of $\$ 39,927$. Thirteen percent of Dallas County residents live below the federal poverty level, slightly lower than the statewide average of 15 percent. Dallas County's unemployment rate totals 4 percent, the same as the statewide average. Women with children under 18 years of age head 9 percent of the households in Dallas Countyapproximately equal to the statewide average of 8 percent.

\section{Who Returned to Dallas County?}

- In 2001, 7,971 released prisoners (14.6 percent of all releases) returned to Dallas County, at a rate of 3.6 prisoners per 1,000 residents.

- Fifty-one percent $(4,065)$ of Dallas County's returning prisoners were released to mandatory supervision (MS) or parole (figure 6.3). The largest share (10.4 percent, or 423) returned to zip code 75207, where the county's halfway house for parolees, mandatory supervision releasees, and probationers is located. At any given time, this halfway house holds approximately 18 probationers and 182 parole and MS releasees; it served approximately 960 individuals in $2003 .{ }^{180}$ The next largest share (9.4 percent, or 382) of parole and MS releases returned to zip code 75216.

- Forty-seven percent $(3,746)$ of Dallas County's returning prisoners were unsupervised upon release, and 2 percent (160) were released to shock probation (return zip codes were unavailable for these groups).

- Three-quarters (74 percent) of ex-prisoners returning to Dallas County in 2001 were male, a significantly smaller percentage than releases across the state ( 86 percent).

- The racial and ethnic distribution of prisoners returning to Dallas County differs greatly from that of the county's residents: Compared with residents, returning prisoners are more than twice as likely to be non-Hispanic black (55 versus 20 percent), less likely to be non-Hispanic white (26 versus 44 percent), and less likely to be Hispanic (17 versus 31 percent). The remaining 2 percent of ex-prisoners were of other or unknown races or ethnicities. This distribution approximates that of released prisoners across Texas.

- Compared with the statewide average, a significantly higher percentage of ex-prisoners returning to Dallas County had been incarcerated for a drug offense (58 percent versus 39 percent). The next largest percentage had been incarcerated for property offenses. Notably, less than 1 percent of prisoners going to Dallas County had been incarcerated for violent offenses - a tiny fraction of the statewide average of 17 percent (figure 6.4). 
Figure 6.3. Percentage of supervised releasees to Dallas County by zip code, 2001
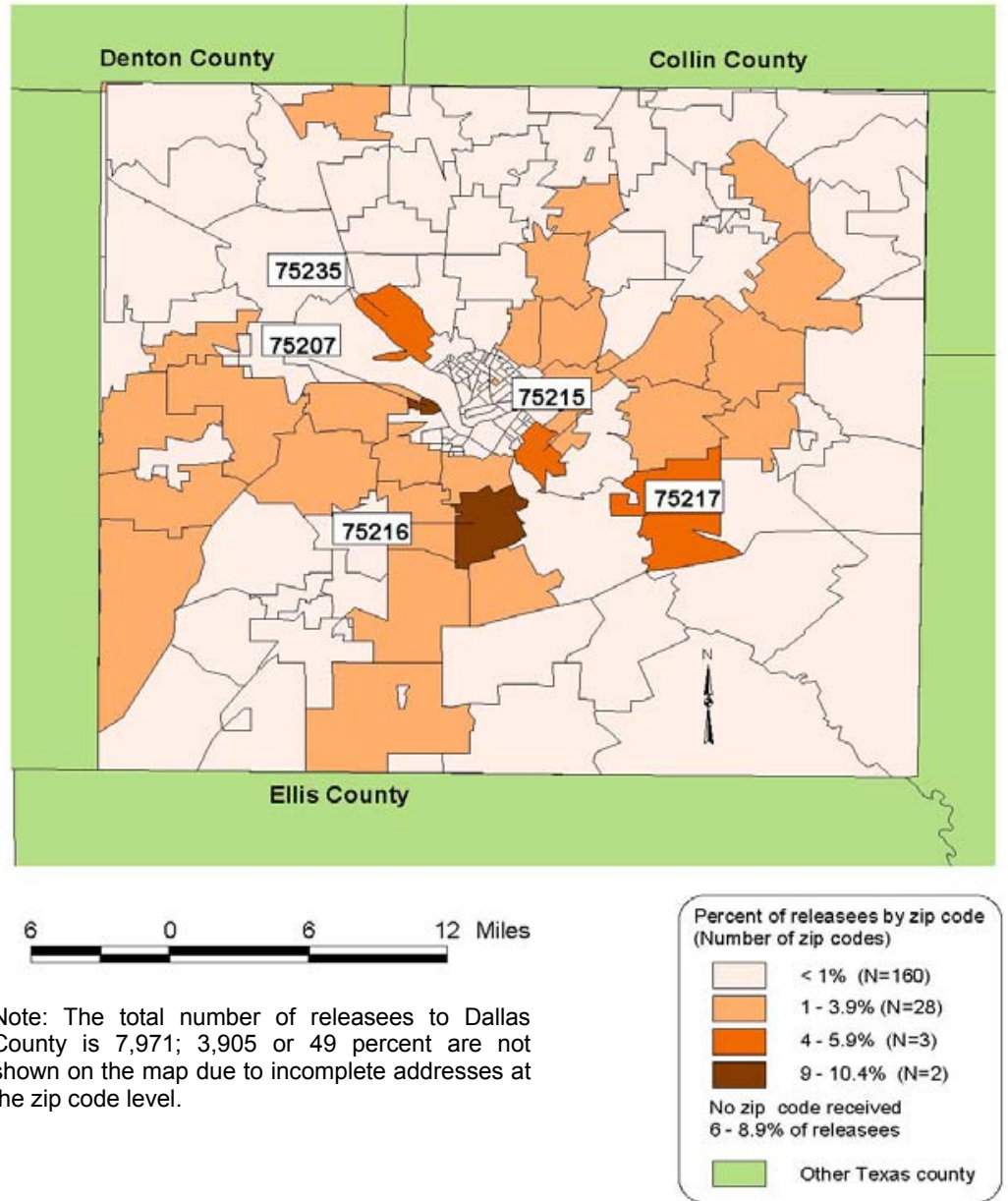

Note: The total number of releasees to Dallas County is 7,$971 ; 3,905$ or 49 percent are not shown on the map due to incomplete addresses at the zip code level.

Source: Urban Institute analysis of 2001 TDCJ data.

Figure 6.4. Offense types of Dallas County prisoner releasees and all Texas prisoner releasees, 2001

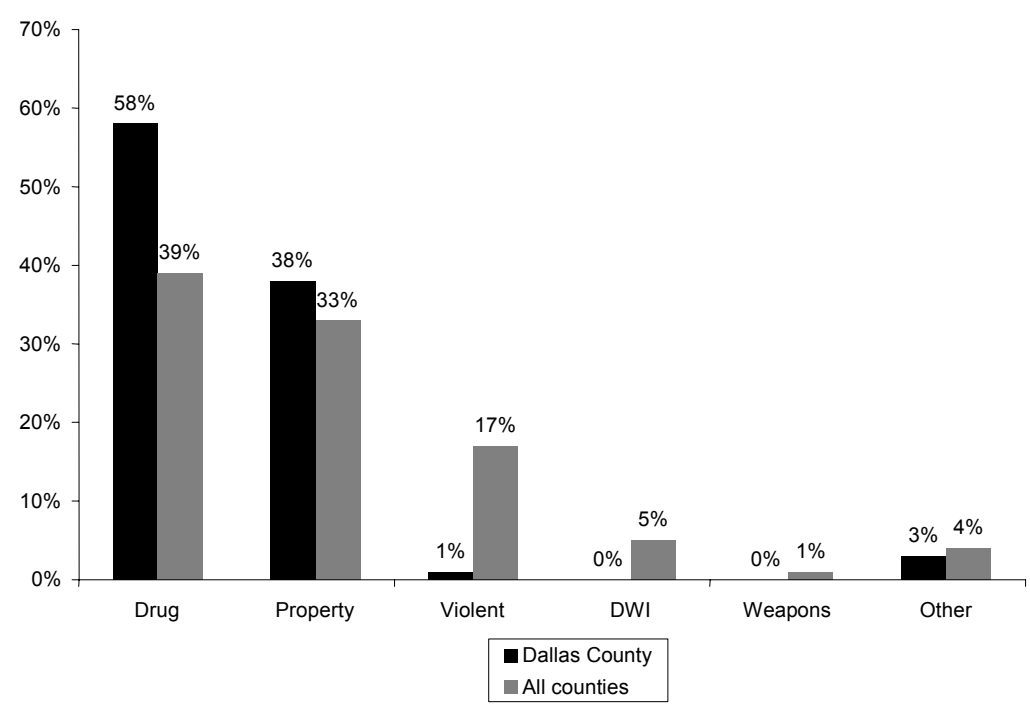

Source: Urban Institute analysis of 2001 TDCJ data.

Note: Figures total more than 100 percent due to rounding. 


\section{PRISONER REENTRY IN TARRANT COUNTY}

Tarrant County, which includes the city of Fort Worth, is home to nearly 1.5 million residents, making it the third largest county in the state in population. Approximately 11 percent of its residents live below the poverty level-lower than the state average of 15 percent - and its median household income of $\$ 46,179$ is 16 percent higher than the statewide median household income of $\$ 39,927$. The unemployment rate in Tarrant County and the percentage of femaleheaded households with children under 18 years of age is nearly equal to the state average of 4 and 8 , respectively.

\section{Who Returned to Tarrant County?}

- In 2001, 4,097 released prisoners (7.5 percent of all releases) returned to Tarrant County, at a rate of 2.8 prisoners per 1,000 residents.

- Sixty-one percent $(2,499)$ of Tarrant County's returning prisoners were released to MS or parole (figure 6.5). The largest share (17.1 percent, or 427) returned to zip code 76107, where the county's parole and MS halfway house is located. This halfway house holds approximately 225 people at any time and served approximately 700 individuals in $2003 .{ }^{181}$ The next largest share (12.4 percent, or 310) returned to zip code 76119.

- Thirty-eight percent $(1,557)$ of Tarrant County's returning prisoners were unsupervised upon release and 1 percent (41) were released to shock probation (return zip codes were unavailable for these groups).

- The majority of these releasees were male (91 percent) - slightly higher than the percentage of male prisoner releasees across the state ( 86 percent).

- Most Tarrant County releasees were Hispanic (59 percent), a significantly higher percentage than for releasees across Texas (24 percent) and for the Tarrant County resident population (22 percent). One-quarter of prisoners returning to Tarrant County were non-Hispanic white, compared with 32 percent of all prisoners returning to Texas and 61 percent of Tarrant County residents. The percentage of Tarrant County releasees who were non-Hispanic black (17 percent) is significantly lower than the percentage of statewide releasees who were (44 percent).

- Similar to the distribution among ex-prisoners across the state, one-third of those returning to Tarrant County had been incarcerated for a drug offense, one-third had been incarcerated for a property offense, and 17 percent had been incarcerated for a violent offense (figure 6.6). However, twice as many prisoners released to Tarrant County had been incarcerated for a driving while intoxicated offense as had been statewide (11 versus 5 percent). 
Figure 6.5. Percentage of supervised releasees to Tarrant County by zip code, 2001
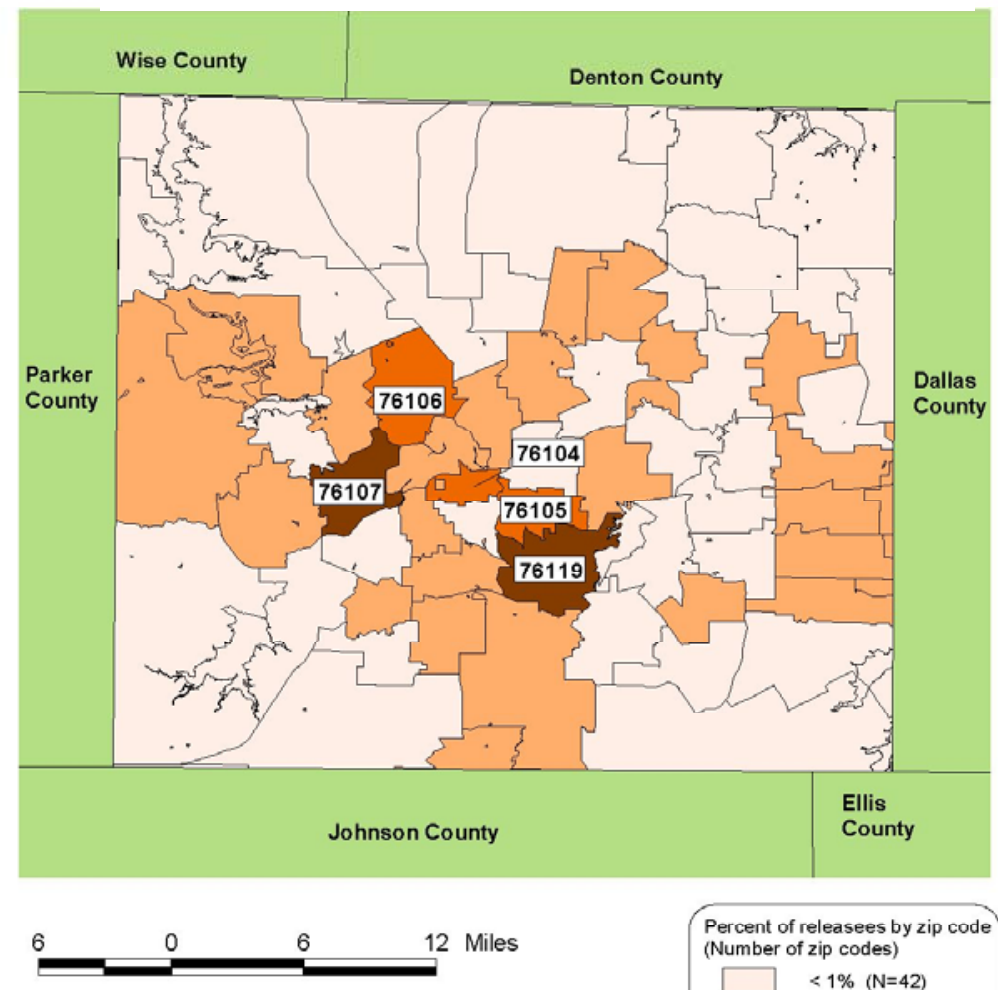

Note: The total number of releasees to Tarrant County is 4,$097 ; 1,611$ or 39 percent are not shown on the map due to incomplete addresses at the zip code level.

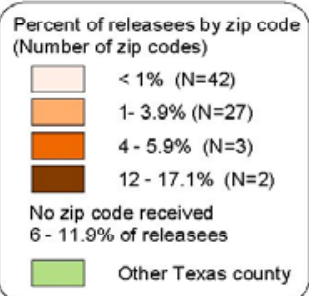

Source: Urban Institute analysis of 2001 TDCJ data.

Figure 6.6. Offense types of Tarrant County prisoner releasees and all Texas prisoner releasees, 2001

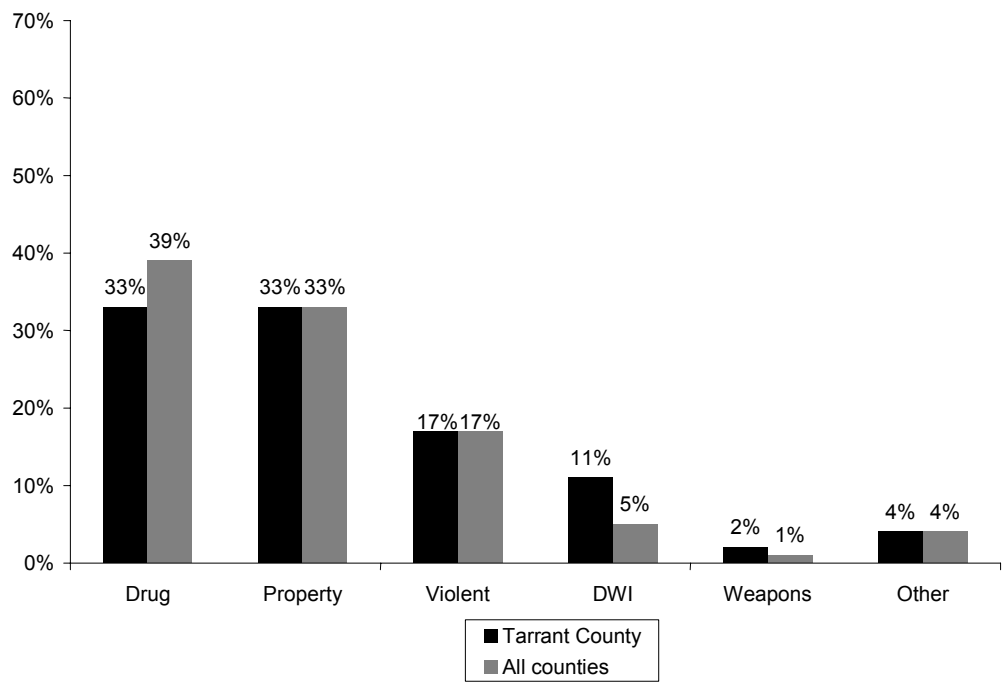

Source: Urban Institute analysis of 2001 TDCJ data.

Note: Figures total more than 100 percent due to rounding. 


\section{PRISONER REENTRY IN BEXAR COUNTY}

Bexar County, which encompasses the city of San Antonio, has close to 1.4 million residents. The median household income in the county is $\$ 38,328$ - close to the statewide median household income of $\$ 39,927$. Sixteen percent of Bexar County residents live below the poverty level, approximating the statewide average of 15 percent. The unemployment rate in Bexar County (4 percent) equals the statewide average. Female-headed households account for 9 percent of all households, compared with 8 percent across the state.

\section{Who Returned to Bexar County?}

- In 2001, 3,156 released prisoners returned to Bexar County, at a rate of 2.3 prisoners per 1,000 residents.

- Sixty percent $(1,894)$ of Bexar County's returning prisoners were released to MS or parole (figure 6.7). The largest share (12.9 percent, or 244) returned to zip code 78203, where a halfway house for parole and MS releasees is located. This facility houses approximately 42 individuals at any given time and served about 200 individuals in $2003 .^{182}$ The next largest share (7.4 percent, or 140) returned to zip code 78207.

- Thirty-eight percent $(1,199)$ of Bexar County's returning prisoners were unsupervised upon release, and 2 percent (63) were released to shock probation (return zip codes were unavailable for these groups).

- The majority of the returning prisoners were male (91 percent), a slightly higher percentage than across the state (86 percent).

- The racial distribution of returning prisoners was similar to the distribution of exprisoners across the state, but differed significantly from the distribution among Bexar County residents. Twenty-nine percent of prisoners returning to Bexar County were Hispanic, while 59 percent of county residents were. Forty-one percent of releasees were non-Hispanic black, while 5 percent of residents were. And 29 percent of releasees were non-Hispanic white, while 35 percent of residents were. Approximately 1 percent of releasees were of other or unknown race or ethnicity.

- Notably, the most common conviction offense among those returning to Bexar County was violent offenses (62 percent), which is significantly higher than the 17 percent of prisoners released statewide who were incarcerated for violent offenses. Of these violent offenses, most (41 percent) were assaults, 30 percent were robberies, 19 percent were sexual assaults, 7 percent were homicides, and 1 percent were kidnapping. Only 13 percent of Bexar releases had been convicted of drug offenses and only 13 percent had been convicted for property offenses (figure 6.8). Bexar is the only county in Texas in which violent offenses represent the most common conviction type of released prisoners. 
Figure 6.7. Percentage of supervised releasees to Bexar County by zip code, 2001

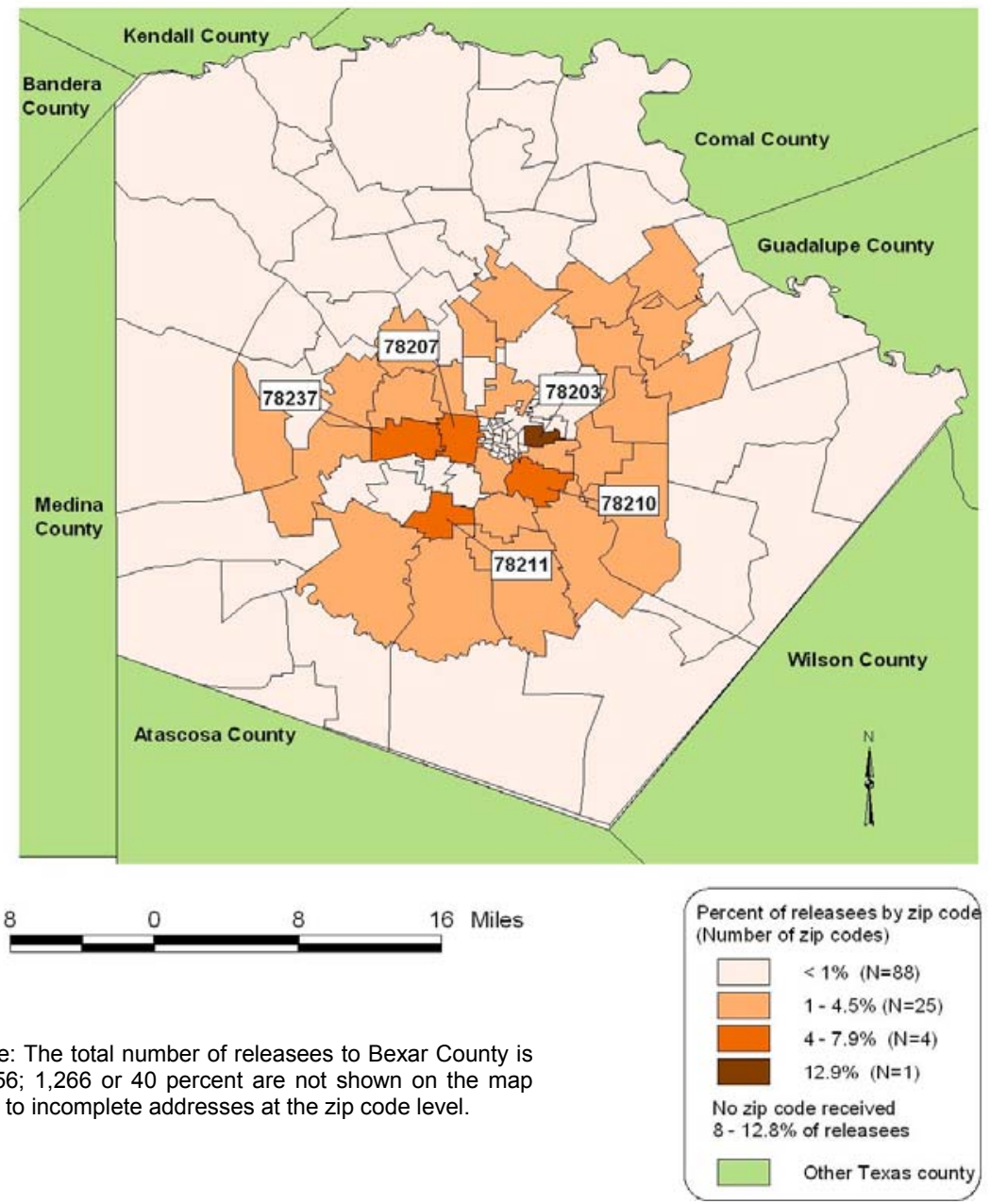

Source: Urban Institute analysis of 2001 TDCJ data.

Figure 6.8. Offense types of Bexar County prisoner releasees and all Texas prisoner releasees, 2001

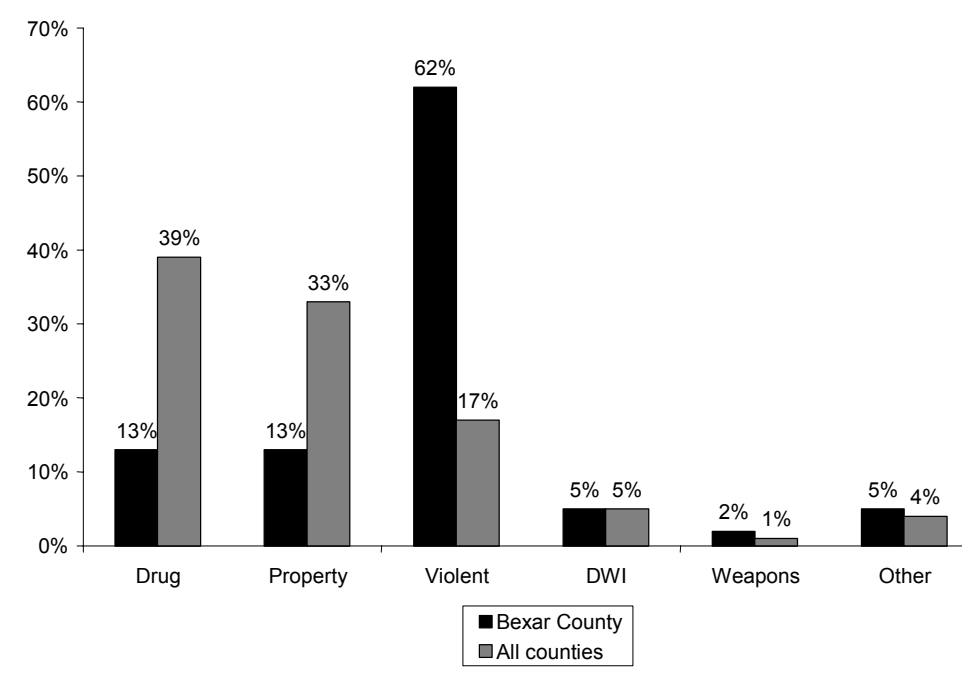

Source: Urban Institute analysis of 2001 TDCJ data.

Note: Figures total more than 100 percent due to rounding. 


\section{PRISONER REENTRY IN TRAVIS COUNTY}

Travis County is one of the smaller counties that contain a metropolitan city, Austin, and it is one of the more economically advantaged counties in the state. Thirteen percent of its 812,280 residents live below the poverty level (compared with 15 percent statewide), and its median household income $(\$ 46,761)$ is 17 percent above the statewide median of $\$ 39,927$. Travis County's unemployment rate (3 percent) is lower than the statewide average of 4 percent. Approximately 6 percent of households in the county are female-headed, close to the statewide average of 8 percent.

\section{Who Returned to Travis County?}

- In 2001, 2,342 released state prisoners returned to Travis County, at a rate of 2.9 prisoners per 1,000 residents.

- Fifty-seven percent $(1,335)$ of the county's returning prisoners were released to MS or parole (figure 6.9). The largest share (36.7 percent, or 490) returned to zip code 78617, where a halfway house for parolees, MS releases, and probationers is located. On any given day, this facility houses approximately 130 parolees and mandatory supervision releasees along with 50 probationers. It served approximately 650 individuals in $2003 .{ }^{183}$ The next largest share (7.5 percent) of ex-prisoners returned to zip code 78702 .

- Forty-two percent (984) of the county's returning prisoners were unsupervised upon release and 1 percent (23) were released to shock probation (return zip codes were unavailable for these groups).

- Most (89 percent) of the released state prisoners who returned to Travis County were male, approximately the same percentage as those released throughout the state.

- The racial composition of prisoners returning to Travis County is more similar to the statewide distribution of prisoners than the other counties discussed above; but like the other counties, the racial composition of the releases to Travis County departs from the racial composition of the county's general population. Non-Hispanic whites accounted for 38 percent of the releasees to Travis County, while they account for 56 percent of the county's residents. Hispanics account for 33 percent of the county's releasees and 29 percent of its residents. Non-Hispanic blacks accounted for 28 percent of the county's releasees and only 9 percent of its residents.

- Travis County releasees had been incarcerated for offenses similar to prisoners released across the state. Forty percent of ex-prisoners returning to Travis County had been incarcerated for property offenses, 28 percent had been incarcerated for drug offenses, and 15 percent had been incarcerated for violent offenses (figure 6.10). 
Figure 6.7. Percentage of supervised releasees to Travis County by zip code, 2001
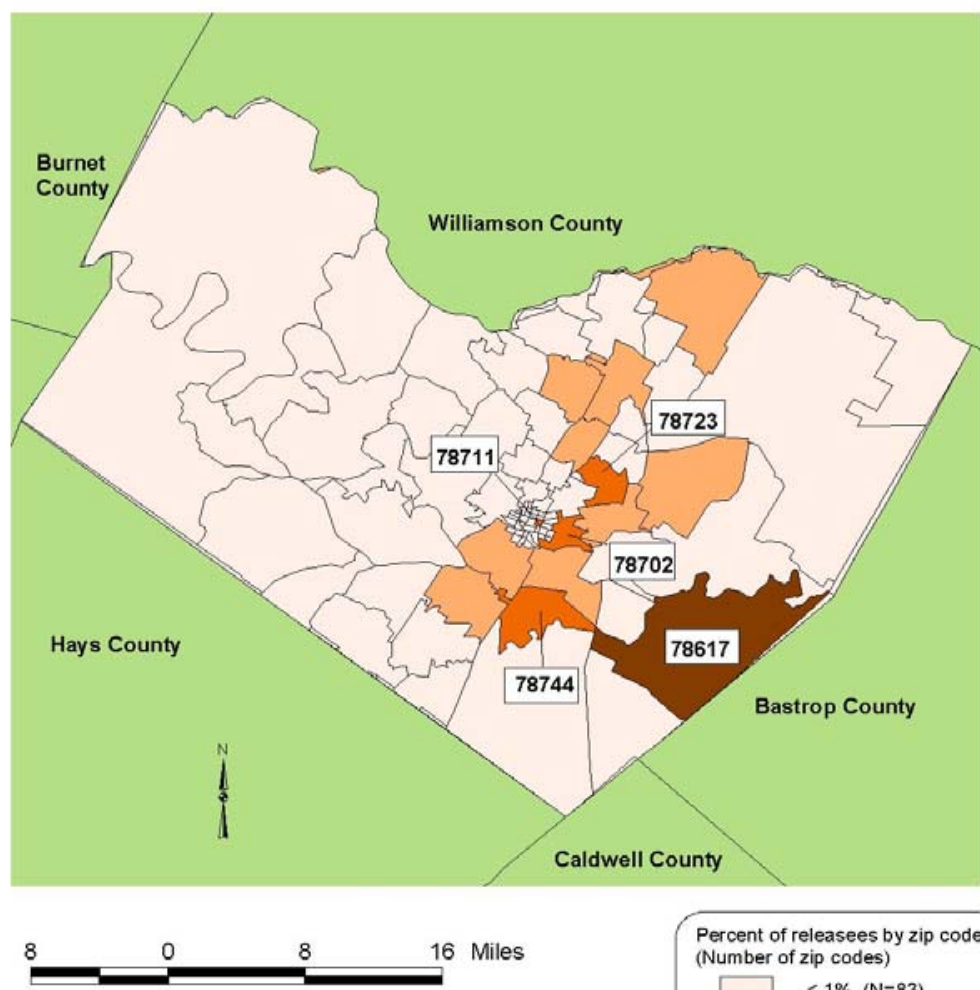

Percent of releasees by zip code (Number of zip codes)

Note: The total number of releasees to Travis County is 2,342; 1,012 or 43 percent are not shown on the map due to incomplete addresses at the zip code level.

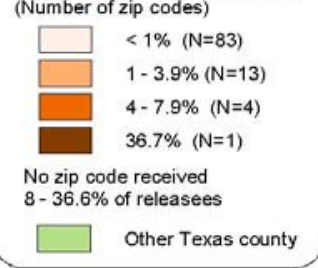

Source: Urban Institute analysis of 2001 TDCJ data.

Figure 6.10. Offense types of Travis County prisoner releasees and all Texas prisoner releasees, 2001

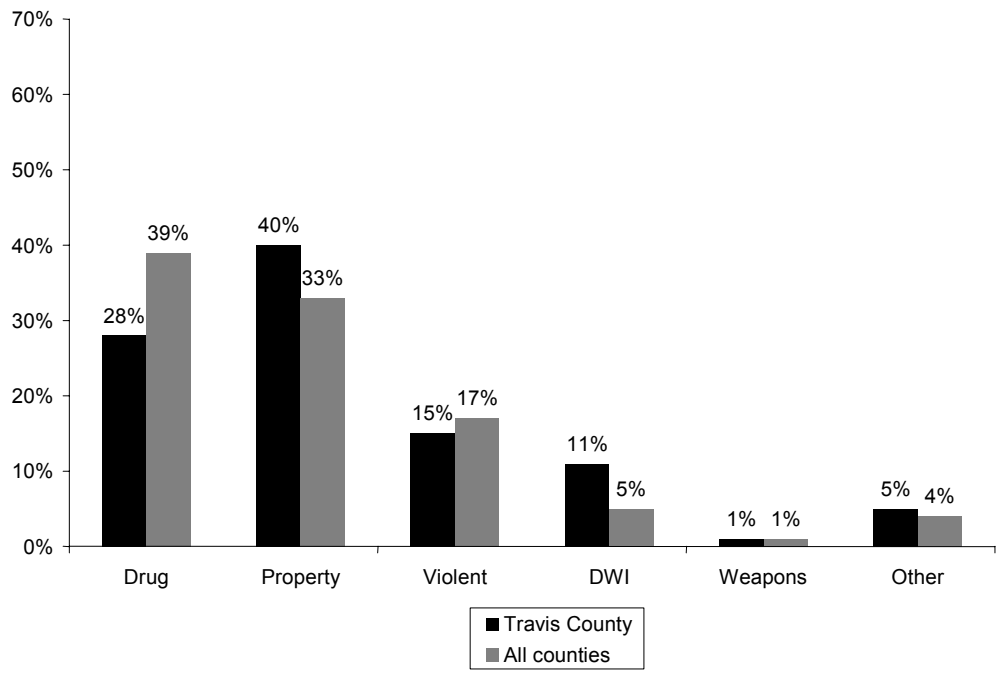

Source: Urban Institute analysis of 2001 TDCJ data.

Note: Figures total more than 100 percent due to rounding. 


\section{PRISONER REENTRY IN HARRIS COUNTY}

With more than three million residents, Harris County is the most populous county in the state and the third largest in the United States. Approximately 15 percent of the population lives below the poverty level, equal to the state average. Harris County's unemployment rate (4.2 percent) is slightly higher than the statewide average of 3.8 percent. Its median household income of $\$ 42,598$ is 7 percent higher than the statewide median household income of $\$ 39,927$. Female-headed households with children under 18 years of age account for nearly 8.3 percent of all households in the county-just above the statewide average of 7.6 percent. ${ }^{184}$

\section{Who Returned to Harris County?}

- In 2001, 14,129 released prisoners returned to Harris County, at a rate of 4.2 returning prisoners per 1,000 residents.

- Forty-seven percent $(6,641)$ of the county's returning prisoners were released to MS or parole (figure 6.11). The largest share (8.1 percent, or 538) returned to zip code 77072. The next largest share (5.2 percent, or 348 ) returned to zip code 77078 , where a halfway house for parolees, MS releases, and probationers is located. This halfway house held 393 parole and MS releases along with 23 probationers as of February 19, 2004, and it served 1,192 individuals in $2003 .{ }^{185}$

- Fifty-two percent $(7,347)$ of the county's returning prisoners were unsupervised upon release, and 1 percent (141) were released to shock probation (return zip codes were unavailable for these groups).

- The majority of the prisoners who returned to Harris County in 2001 were male (87 percent), similar to prisoners released across the state.

- Forty-one percent of prisoners returning to Harris County were non-Hispanic white, mirroring the proportion of residents who are non-Hispanic white. In contrast, 45 percent of Harris County releasees were non-Hispanic black, while only 18 percent of residents were. At the same time, 14 percent of prisoners returning to Harris County were Hispanic, compared with 33 percent of the county's residents. Less than 1 percent of prisoners released to Harris County were of other or unknown racial background, and 6 percent of Harris County residents are of Asian or other racial or ethnic backgrounds.

- As with returning prisoners across Texas, the largest share of released prisoners returning to Harris County had been incarcerated for drug offenses (36 percent), the second largest share had been incarcerated for property offenses (33 percent), and the third largest share had been incarcerated for violent offenses (17 percent) (figure 6.12). 
Figure 6.11. Percentage of supervised releasees to Harris County by zip code, 2001

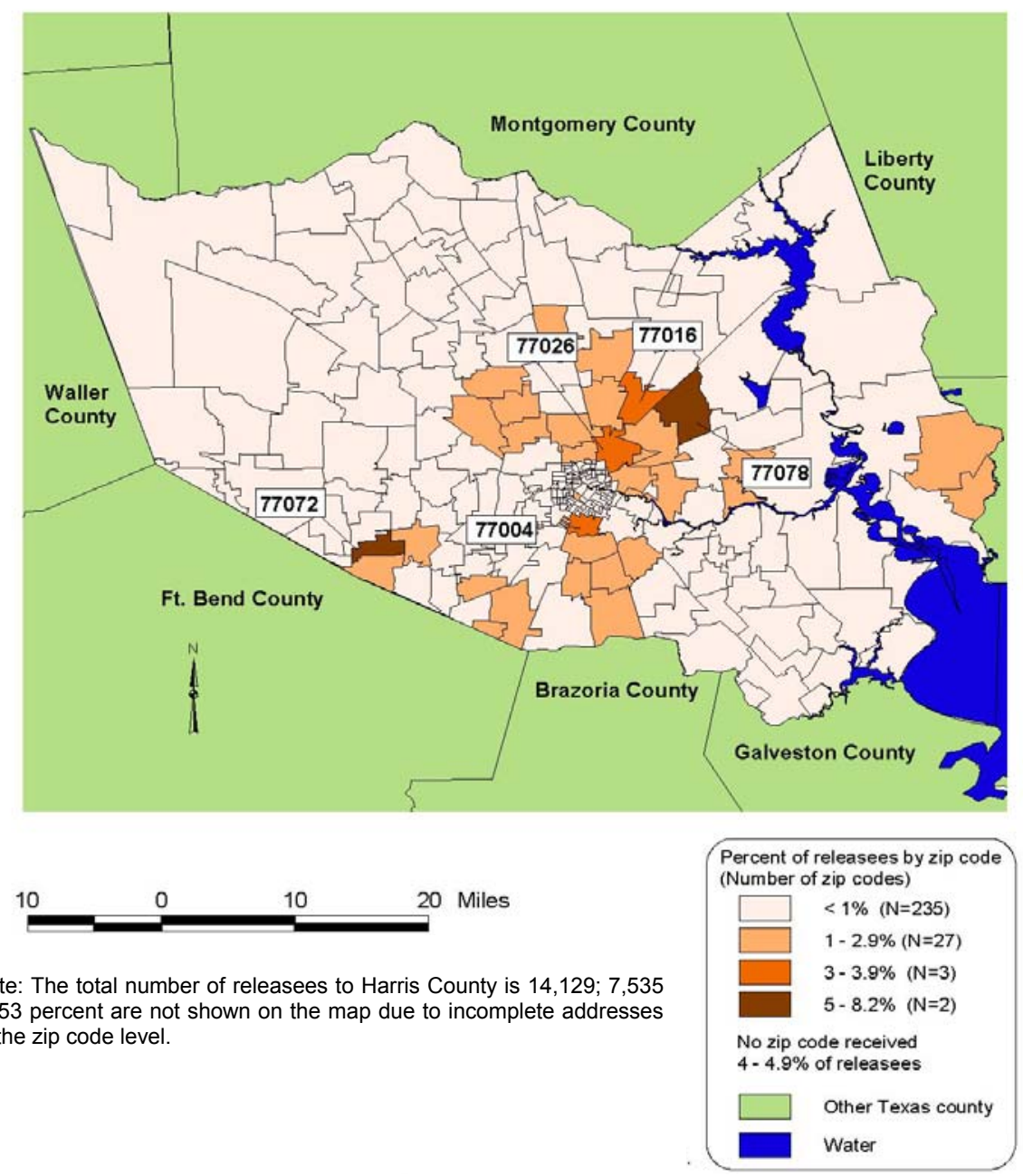

Source: Urban Institute analysis of 2001 TDCJ data.

Figure 6.12. Offense types of Harris County prisoner releasees and all Texas prisoner releasees, 2001

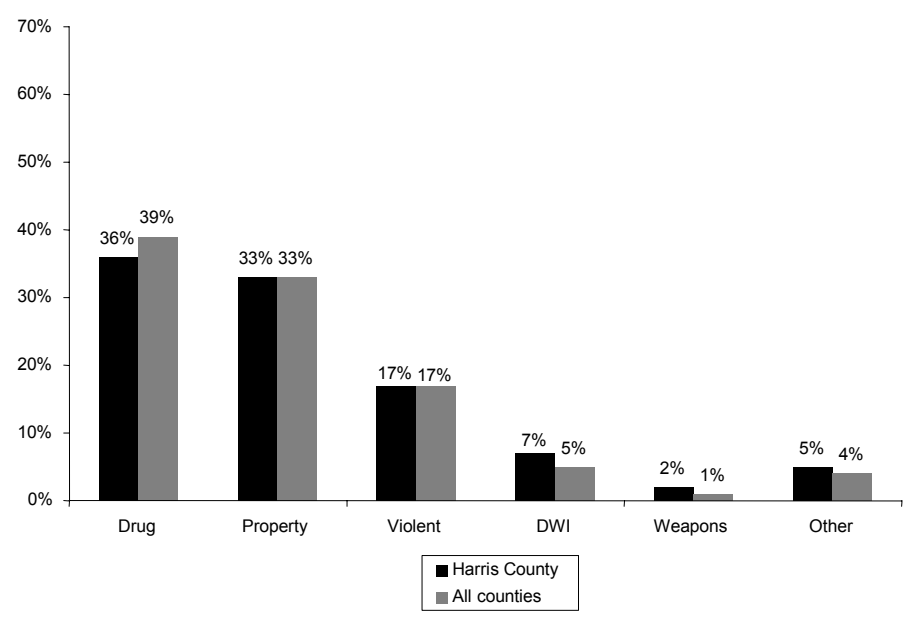

Source: Urban Institute analysis of 2001 TDCJ data.

Note: Figures total more than 100 percent due to rounding. 



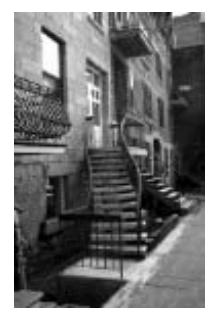

\section{H A P T E R 7 To Which Houston Neighborhoods Are Texas Prisoners Returning?}

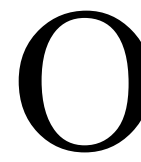
ne in four Texas prisoners return to Harris County. Nearly half (47 percent) of all releases in 2001 to Harris County were released to parole or mandatory supervision (MS), and the vast majority ( 88 percent) of these supervised releasees returned to Houston. Not only does Houston receive the largest number of supervised releasees $(5,823$ men and women in 2001), it also represents a much higher rate of return than the statewide average. Supervised releasees returned to Houston at a rate of 3.1 released prisoners for every 1,000 residents, versus a statewide rate of 1.1 released prisoners for every 1,000 residents, and a rate of 1.9 released prisoners for every 1,000 residents in Harris County. ${ }^{186}$ For these reasons, we give special attention to Houston.

The nearly two million residents of Houston face similar economic and social conditions as residents of other cities in Texas. The median household income in Houston is \$36,616slightly below the statewide median household income of $\$ 39,927$. Unemployment in Houston totals 5 percent, approximating the statewide average of 4 percent. And almost a fifth (19 percent) of Houston's residents live below the federal poverty level, which is slightly higher than the statewide average of 15 percent. In addition, female-headed households account for 9 percent of the households in Houston, close to the statewide average of 8 percent. The crime rate in Houston is 73.8 incidents per 1,000 residents, 43 percent higher than the statewide average of 51.5.

The impact of prisoner reentry is felt most acutely in a small number of Houston's neighborhoods. A quarter of all supervised releasees returning to Houston are concentrated in 5 of the city's 185 zip codes (the return zip code is unknown for prisoners who are not subject to postrelease supervision). Notably, the zip code receiving the second greatest share of returning supervised releasees includes a halfway house, which may explain the relatively large number of prisoners returning there. These five high-return zip codes overlap largely with 7 of the city's 88 "super neighborhoods"- they are among the city's most economically disadvantaged neighborhoods. These neighborhoods and their characteristics are further discussed below. 


\section{OVERVIEW OF RELEASED PRISONERS WHO RETURNED TO HOUSTON}

Reflecting the characteristics of all prisoners returning to Texas in general, the majority of supervised releasees returning to Houston in 2001 were male (86 percent), 37 years old on average, and single. ${ }^{187}$ In contrast to the general cohort of returning prisoners, Houston supervised releasees are slightly more likely to be non-Hispanic black ( 49 versus 44 percent), more likely to be non-Hispanic white (43 versus 32 percent), and significantly less likely to be Hispanic (8 versus 24 percent). As is the case with Texas releasees, less than 1 percent of all Houston supervised releasees are of an unknown or other race or ethnicity. By way of comparison, nonHispanic blacks represent 25 percent of Houston's residents, non-Hispanic whites comprise 31 percent of the residents, Hispanics represent the greatest share of Houston's residents (37 percent), and other racial groups make up the remaining 7 percent of the residents (figure 7.1). Given that the Hispanic population is so large in Houston, it is noteworthy that a small percentage of supervised releasees returning to the city are Hispanic.

The same percentage of supervised releasees returning to Houston had been convicted of a property offense as had been convicted of a drug offense (34 percent in both cases), making property offenses slightly more common among Houston supervised releasees than in the exprisoner cohort as a whole. Houston supervised releasees were also slightly more likely than the average Texas releasee to have been convicted of driving while intoxicated (DWI) (9 versus 5 percent). The remaining offenses were distributed similarly across both cohorts (figure 7.2). On average, nearly a third (29 percent) of Houston supervised releasees had served less than two years in state jail or prison, and approximately the same percentage ( 28 percent) had served between 5 and 10 years.

Although this information is unavailable at the city level, analysis of the data revealed that 18 percent of prisoners released to Harris County (most of whom likely returned to Houston) were confinees and the rest were state prisoners. In 2001, 47 percent of ex-prisoners who returned to Harris County were released conditionally - that is, they were subject to some period of postrelease supervision. Nearly half (48 percent) of these prisoners were released to parole, slightly more than half (52 percent) were released to mandatory supervision, and a negligible share (less than 1 percent) were released to shock probation. The likelihood that prisoners released to supervision will violate the conditions of their parole or mandatory supervision is substantial. Of the prisoners released to supervision in Houston in 2001, 45 percent had violated parole or mandatory supervision at the time of their most recent incarceration. 
Figure 7.1. Houston residents, Houston supervised releasees, and all TDCJ releasees by race/ethnicity, 2001

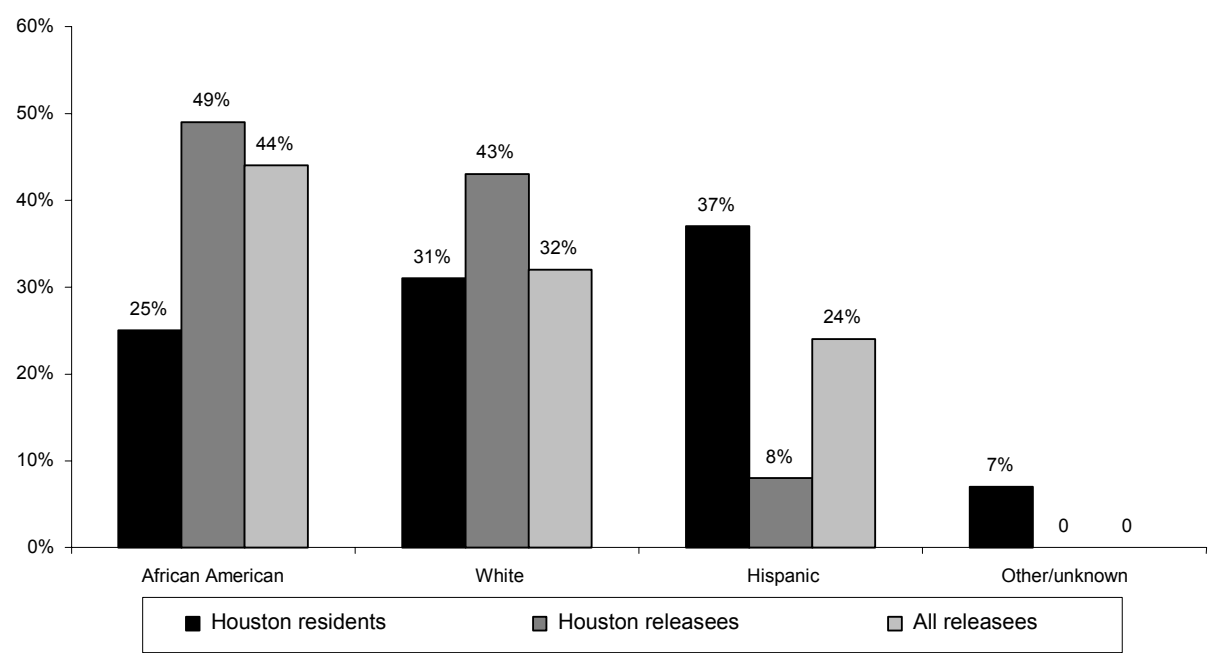

Source: Urban Institute analysis of 2001 TDCJ data.

Figure 7.2. Houston supervised releasees and all TDCJ releasees by offense type, 2001

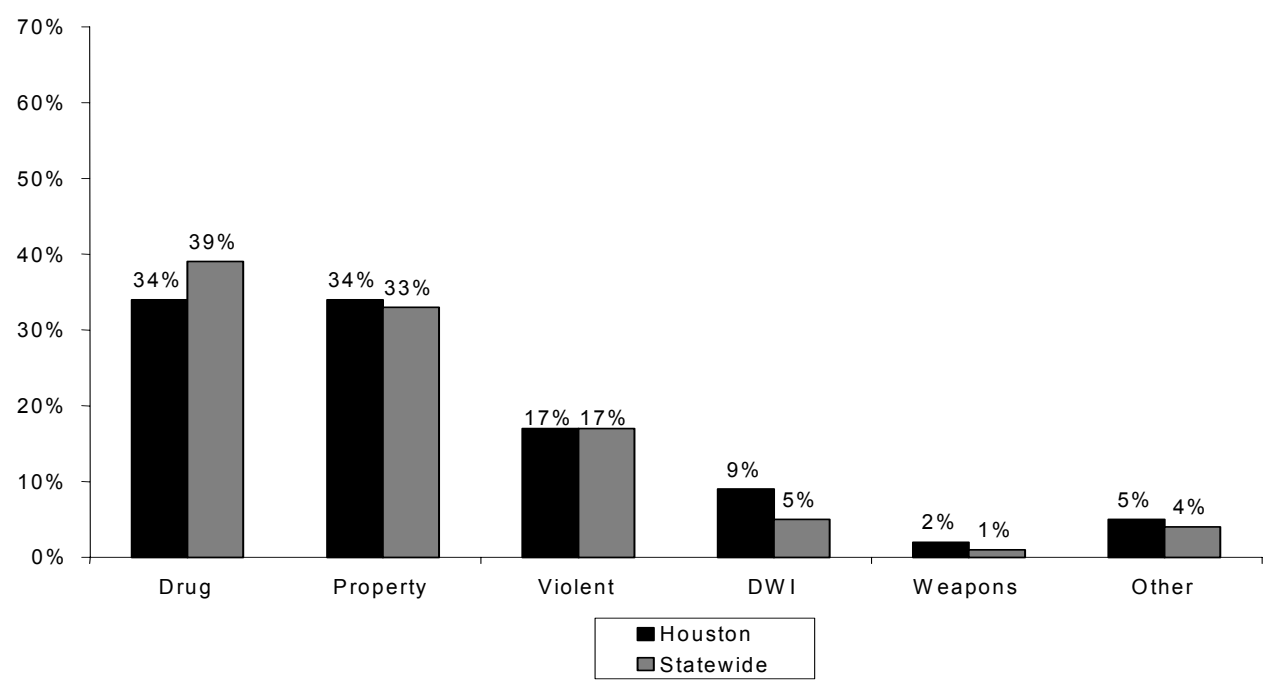

Source: Urban Institute analysis of 2001 TDCJ data.

Note: Figures total more than 100 percent due to rounding.

\section{PRISONER REENTRY IN HOUSTON NEIGHBORHOODS}

In Texas, supervised releasees are not only concentrated in Houston-the largest metropolitan area in the state-but also in certain neighborhoods in Houston. Prisoner reentry affects not only the prisoners who are returning home but also the neighborhoods to which they are returning. Conversely, the characteristics of the neighborhoods to which released prisoners return may affect a prisoner's prospects for successful reentry. For instance, the availability and cost of housing and the availability and proximity of jobs in a neighborhood may influence postrelease outcomes for returning prisoners. In addition, the availability —or absence of — social 
services, such as health care and substance abuse treatment, also is likely to affect reentry transition and recidivism.

As shown in figure 7.3, the distribution of supervised releasees varies widely across Houston, with the largest number returning to the northeast and southwest areas of the city. A quarter (25.9 percent) of all supervised releasees returned to five zip codes (figure 7.4). The rate at which supervised releasees return to each of these five zip codes exceeds the rate at which prisoners return to Houston by between 113 and 674 percent (figure 7.5). The neighborhoods with the largest numbers of returning supervised releasees are Alief, East Houston, Third Ward, MacGregor, Kashmere Gardens, East Little York/Homestead, and Trinity/Houston Gardens-just 7 of Houston's 88 "super neighborhoods." All but one of these neighborhoods received close to or more than 200 released supervised releasees in 2001-higher than the number returning to some entire counties in Texas (figure 7.4).

\section{Figure 7.3. Supervised releasees to Houston's high-return neighborhoods by zip code, 2001}

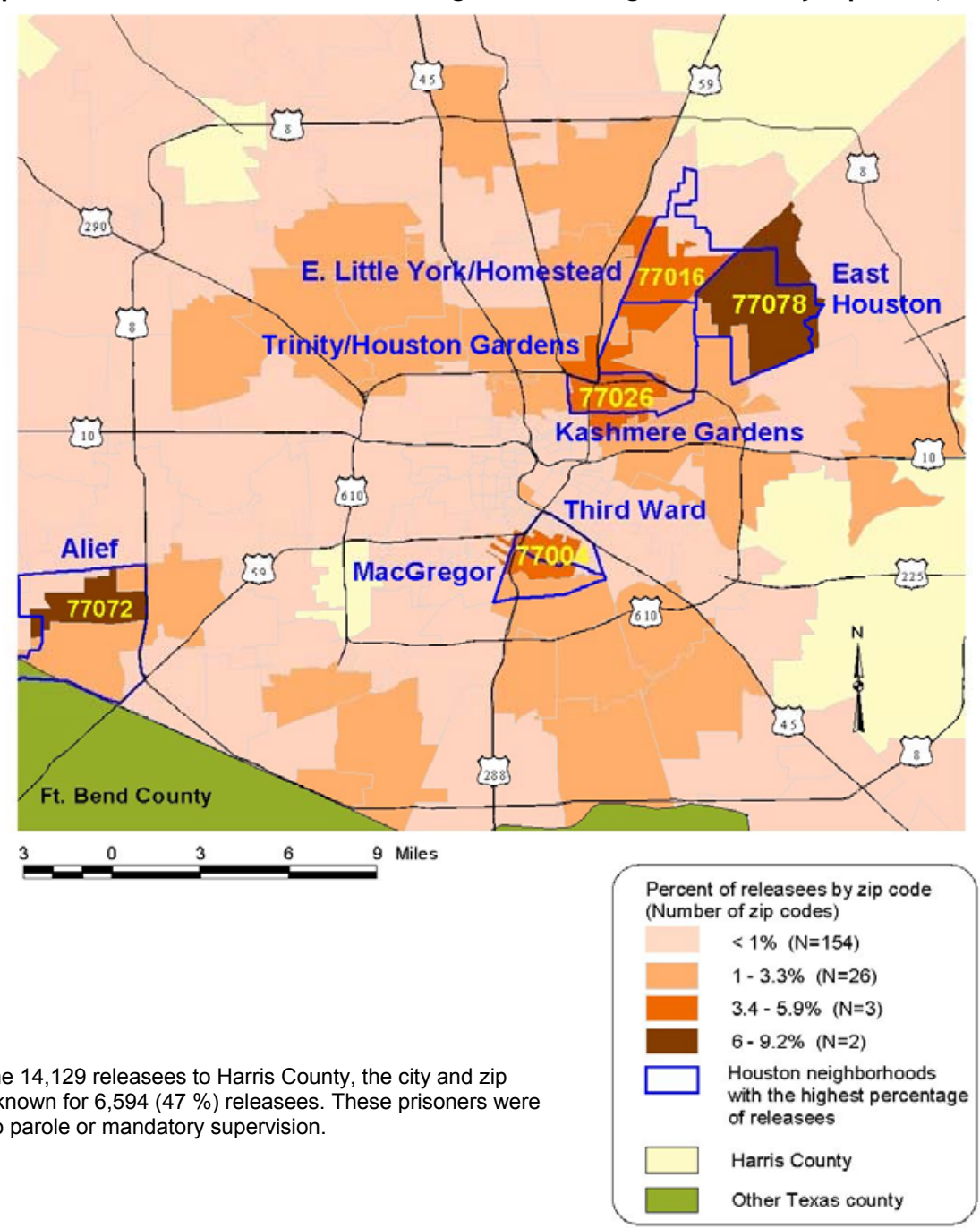

Note: Of the 14,129 releasees to Harris County, the city and zip code was known for 6,594 $(47 \%)$ releasees. These prisoners were released to parole or mandatory supervision. 
Figure 7.4. Numbers and rates of supervised releasees returning to Houston's high-return zip codes, 2001

\begin{tabular}{lcc} 
& $\begin{array}{c}\text { Number of returning } \\
\text { parolees \& MS releasees }\end{array}$ & $\begin{array}{c}\text { Rate per } \\
1,000 \text { residents }\end{array}$ \\
\hline 77072 (Alief) & 538 & 10.4 \\
77078 (East Houston) & 348 & 24.0 \\
77004 (MacGregor/Third Ward) & 216 & 7.3 \\
77026 (Kashmere Gardens; Trinity/Houston Gardens) & 207 & 7.5 \\
77016 (E. Little York/Homestead; Trinity/Houston Gardens) & 196 & 6.6 \\
Citywide & 5,823 & 3.1 \\
\hline
\end{tabular}

Source: Urban Institute analysis of U.S. Census Bureau data and 2001 TDCJ data.

Figure 7.5. Rates of supervised releasees returning to Texas, Harris County, Houston, and Houston's high-return zip codes (per 1,000 residents), 2001

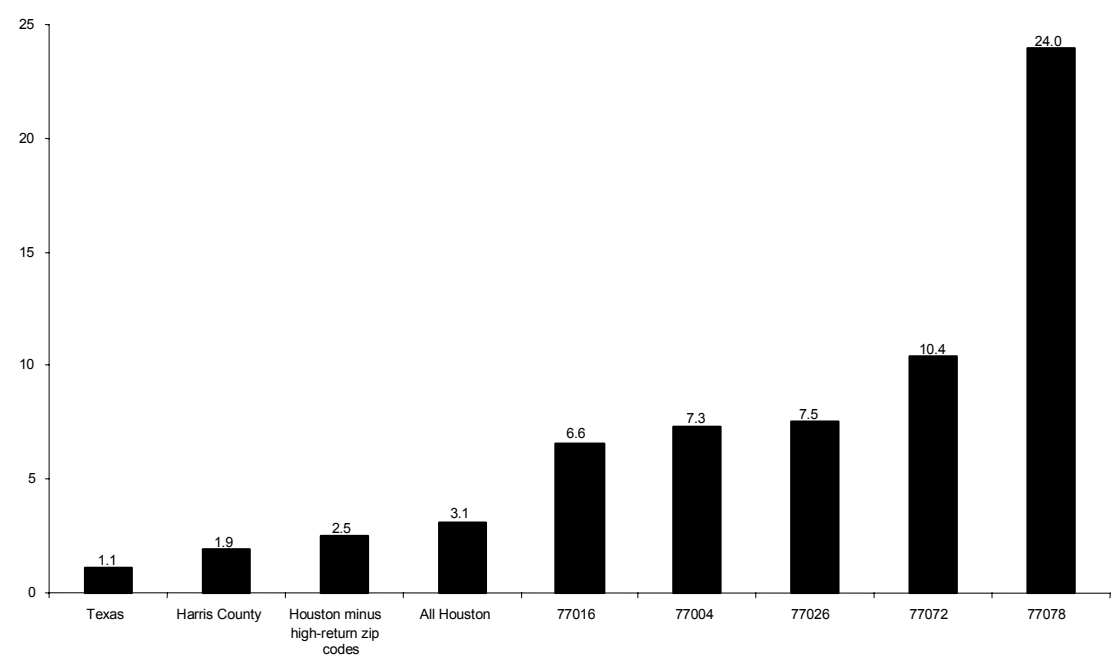

Source: Urban Institute analysis of U.S. Census Bureau data and 2001 TDCJ data.

The return of supervised releasees to these seven neighborhoods is only part of the story. Another important factor is the high rates of people from these communities who are sent to prison and state jail. Such high levels of residents cycling into and out of prison may disrupt social networks and social relationships in communities. Some researchers suggest that communities with weakened social networks have less success promoting informal social control among residents, which can result in increased neighborhood crime, though little is known about this phenomenon. ${ }^{188}$

What we do know is that, in addition to being home to large numbers of returning supervised releasees, some of these areas are among the Houston neighborhoods most affected by poverty, unemployment, crime, and other challenges (figures 7.6 to 7.11). In 2000, the percentages of households in these neighborhoods that were below the poverty level were much higher than the citywide average (all but one neighborhood was above the city average, as shown in figure 7.6. These neighborhoods also have high shares of female-headed households and some experience violent, property, and drug crime at significantly higher levels than the average for Houston. In figure 7.6, we summarize these and other characteristics for the seven neighborhoods that received the highest number of returning supervised releasees in 2001 and rank each 
neighborhood on the basis of key demographic data. Kashmere Gardens and the Third Ward consistently have the highest concentrations of these challenges. We then turn to individual profiles of these seven Houston neighborhoods.

\begin{tabular}{|c|c|c|c|c|c|c|c|c|c|}
\hline $\begin{array}{l}\text { Community } \\
\text { area and zip code }\end{array}$ & $\begin{array}{l}\text { Vacant } \\
\text { housing }\end{array}$ & $\begin{array}{l}\text { Renter } \\
\text { occupied } \\
\text { housing }\end{array}$ & $\begin{array}{l}\text { High } \\
\text { school } \\
\text { graduates }\end{array}$ & Unemployment & Non-white & $\begin{array}{l}\text { Female } \\
\text { headed } \\
\text { households }\end{array}$ & $\begin{array}{l}\text { Persons } \\
\text { below } \\
\text { poverty } \\
\text { level }\end{array}$ & $\begin{array}{l}\text { Violent } \\
\text { crime rate } \\
\text { (per } 1,000 \\
\text { residents) }\end{array}$ & $\begin{array}{l}\text { Drug crime } \\
\text { rate } \\
\text { (per } 1,000 \\
\text { residents) }\end{array}$ \\
\hline Alief (77072) & $6.1 \%$ & $49.3 \%$ & $72.0 \%$ & $7.4 \%$ & $82.6 \%$ & $13.3 \%$ & $16.1 \%$ & 14.0 & 5.0 \\
\hline$\%$ Different from city mean & -25.6 & -1.0 & 2.3 & -2.6 & 19.4 & 51.1 & -14.8 & 14.8 & -3.8 \\
\hline East Houston (77078) & 6.2 & 34.4 & 56.5 & 13.5 & 94.3 & 17.9 & 33.6 & 19.4 & 6.2 \\
\hline$\%$ Different from city mean & -24.4 & -30.9 & -19.7 & 77.6 & 36.3 & 103.4 & 77.8 & 59.0 & 19.2 \\
\hline Third Ward (77004) & 17.6 & 63.8 & 55.8 & 38.8 & 93.4 & 16.1 & 38.1 & 23.9 & 25.5 \\
\hline$\%$ Different from city mean & 114.6 & 28.1 & -20.7 & 410.5 & 35.0 & 83.0 & 101.6 & 95.9 & 390.4 \\
\hline MacGregor (77004) & 12.8 & 48.5 & 84.4 & 8.1 & 90.7 & 11.1 & 26.4 & 14.0 & 8.9 \\
\hline$\%$ Different from city mean & 56.1 & -2.6 & 19.9 & 6.6 & 31.1 & 26.1 & 39.7 & 14.8 & 71.2 \\
\hline Kashmere Gardens (77026) & 12.0 & 49.6 & 51.9 & 14.9 & 99.3 & 14.1 & 36.9 & 57.6 & 36.4 \\
\hline \% Different from city mean & 46.3 & -0.4 & -26.3 & 96.1 & 43.5 & 60.2 & 95.2 & 372.1 & 600.0 \\
\hline $\begin{array}{l}\text { East Little York/ Homestead } \\
\text { (77016) }\end{array}$ & 5.3 & 22.2 & 66.3 & 10.8 & 97.6 & 11.8 & 24.5 & 11.1 & 6.0 \\
\hline$\%$ Different from city mean & -35.4 & -55.4 & -5.8 & 42.1 & 41.0 & 34.1 & 29.6 & -9.0 & 15.4 \\
\hline $\begin{array}{l}\text { Trinity/Houston Gardens } \\
\text { (77016) }\end{array}$ & 10.8 & 34.8 & 55.5 & 16.9 & 98.2 & 12.2 & 33.4 & 20.3 & 14.1 \\
\hline$\%$ Different from city mean & 31.7 & -30.1 & -21.2 & 122.4 & 41.9 & 38.6 & 76.7 & 66.4 & 171.2 \\
\hline City average & $8.2 \%$ & $49.8 \%$ & $70.4 \%$ & $7.6 \%$ & $69.2 \%$ & $8.8 \%$ & $18.9 \%$ & 12.2 & 5.2 \\
\hline
\end{tabular}

Source: Urban Institute analysis of City of Houston data and 2001 TDCJ data.

Figure 7.7. Rate of selected crimes (per 1,000 residents) by Houston neighborhood, 2001

\begin{tabular}{lccrr} 
Neighborhood & $\begin{array}{c}\text { Violent } \\
\text { rate }\end{array}$ & $\begin{array}{c}\text { Burglary } \\
\text { rate }\end{array}$ & $\begin{array}{c}\text { Auto theft } \\
\text { rate }\end{array}$ & $\begin{array}{c}\text { Drug } \\
\text { rate }\end{array}$ \\
\hline Alief & 14.02 & 25.55 & 15.84 & 5.02 \\
MacGregor & 13.79 & 19.50 & 6.64 & 8.86 \\
Third Ward & 23.86 & 18.17 & 7.31 & 28.65 \\
Kashmere Gardens & 57.59 & 53.07 & 37.75 & 36.42 \\
Trinity/Houston Gardens & 20.27 & 26.53 & 14.01 & 14.07 \\
E. Little York/Homestead & 11.11 & 13.10 & 7.68 & 5.96 \\
East Houston & 19.35 & 34.95 & 13.07 & 6.23 \\
& & & & \\
City of Houston & 12.20 & 13.00 & 12.50 & 5.20 \\
\hline
\end{tabular}

Note: The number of crimes per neighborhood is estimated by assigning crimes occurring within that neighborhood's police beats. Because some neighborhoods have more than one police beat, and some police beats span more than one neighborhood, a police beat is considered part of a neighborhood if at least 50 percent of the beat falls within the neighborhood.

Source: Urban Institute analysis of City of Houston data and 2001 TDCJ data. 
Figure 7.8. Percentage of residents below the poverty level by Houston neighborhoods, 2001

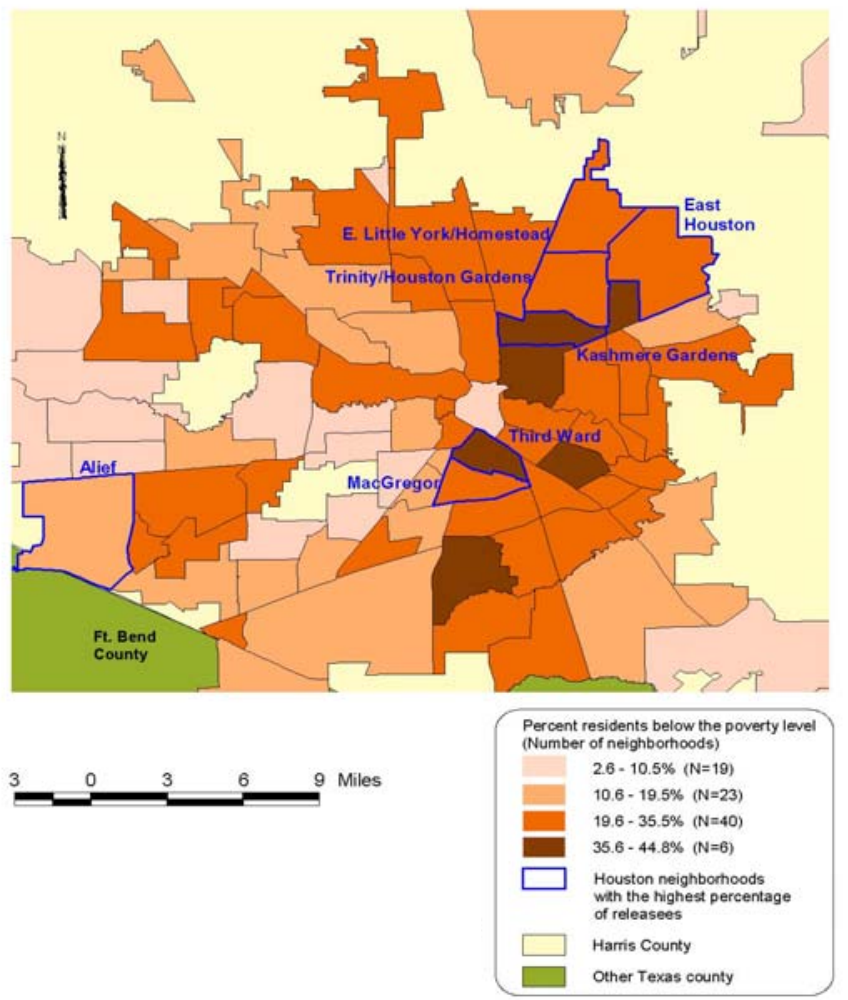

Source: Urban Institute analysis of City of Houston data and 2001 TDCJ data.

Figure 7.9. Percentage of female-headed households by Houston neighborhoods, 2001

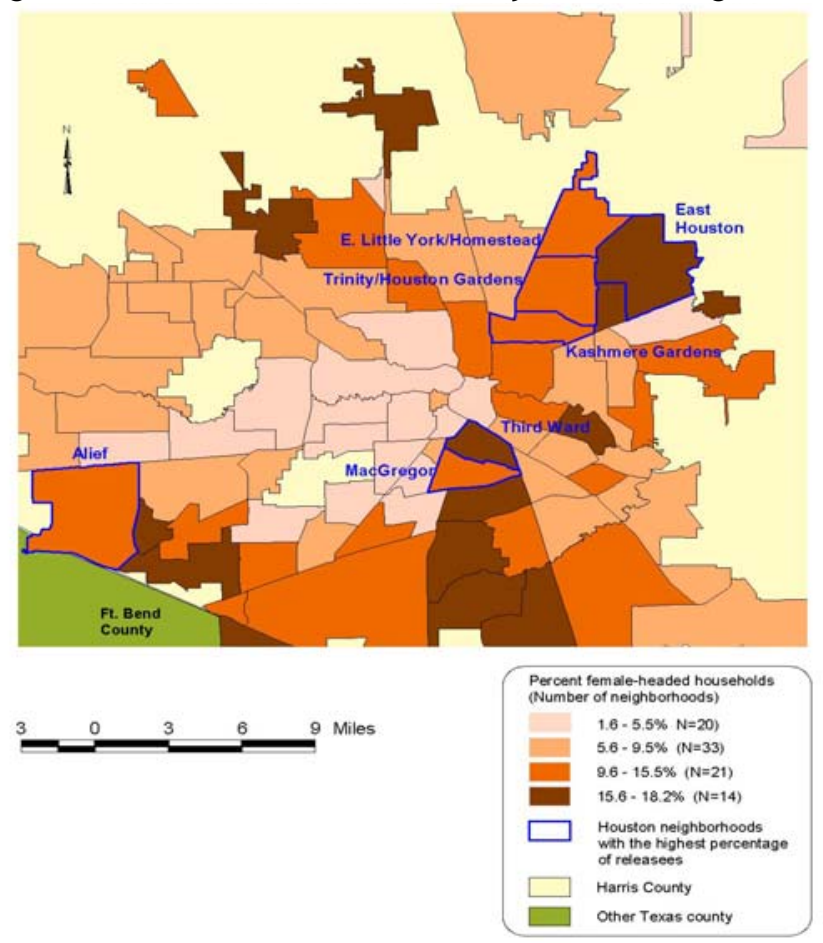

Source: Urban Institute analysis of City of Houston data and 2001 TDCJ data. 
Figure 7.10. Percentage of unemployed residents by Houston neighborhoods, 2001

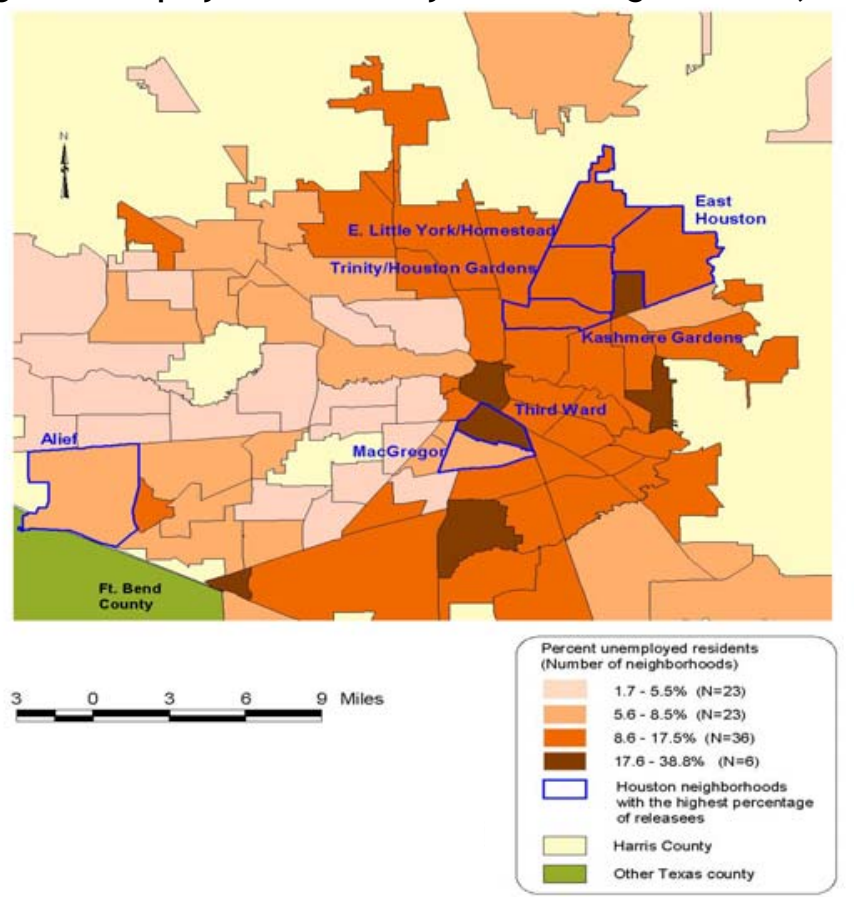

Source: Urban Institute analysis of City of Houston data and 2001 TDCJ data.

Figure 7.11. Percentage of renter-occupied housing by Houston neighborhoods, 2001

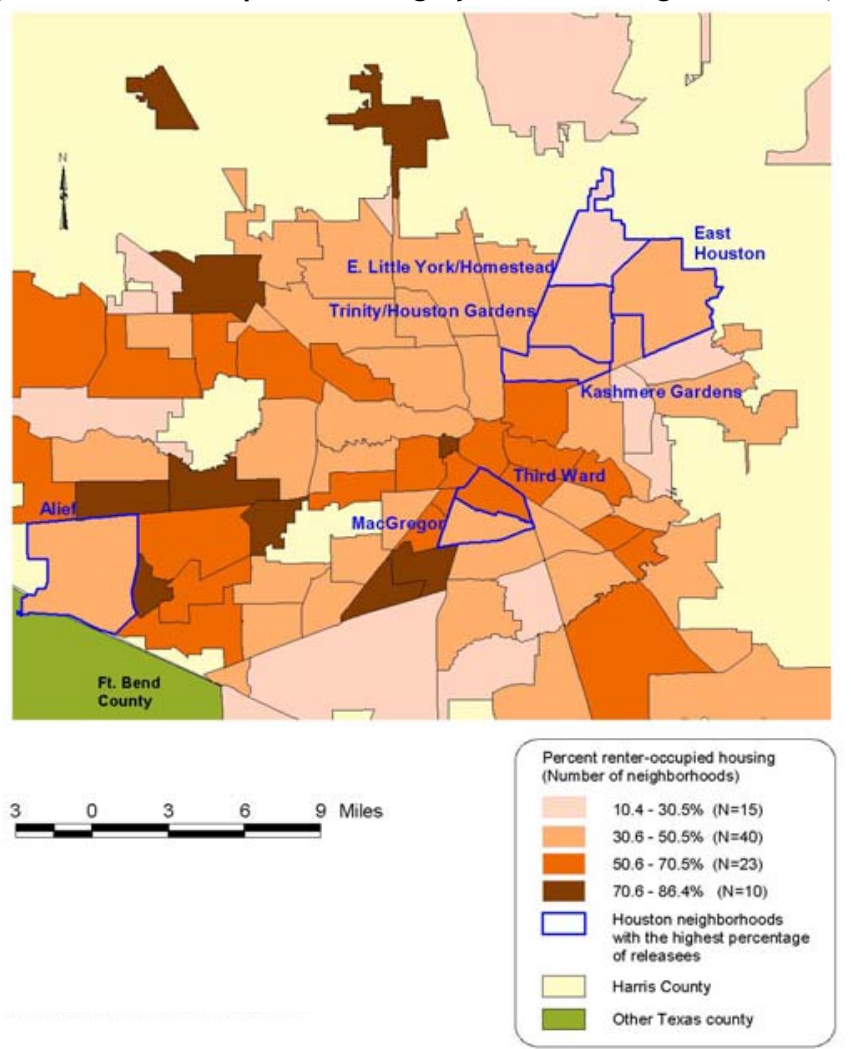

Source: Urban Institute analysis of City of Houston data and 2001 TDCJ data. 
Alief (Zip Code: 77072). In 2001, 538 supervised releasees returned to the 77072 zip code area (population 51,716) at a rate of 10.4 releasees per 1,000 residents (figure 7.4). Sixteen percent of the persons in the associated neighborhood of Alief are living below the poverty level, and the neighborhood has a 7 percent unemployment rate-both rates are slightly below the citywide average. Seventy-two percent of its residents are high school graduates, and the population in this neighborhood is 31 percent Hispanic, 29 percent non-Hispanic black, 21 percent Asian, 17 percent non-Hispanic white, and 2 percent other races or ethnicities. Female-headed households account for 13 percent of the households in this neighborhood, which is 51 percent higher than the citywide rate of 9 percent. The neighborhood is characterized by 6 percent vacant housing, and 49 percent of housing units are renter-occupied. Alief's violent crime rate of 14.0 crimes per 1,000 residents is 15 percent higher than the city average of 12.2 crimes. Property crime is 41.7 per 1,000 residents, or 32 percent lower than the city average of 61.6. The drug crime rate in Alief is 5.0 crimes per 1,000 residents, approximately the same as the city average of 5.2.

East Houston (Zip Code: 77078). In 2001, 348 supervised releasees returned to the zip code of 77078 (est. population 14.479), at a rate of 24 releasees per 1,000 residents. This constitutes the highest rate among the five zip codes receiving the greatest number of supervised releasees, and is 674 percent higher than the citywide rate (figure 7.4). The high rate of return to this zip code may be explained by the presence of a halfway house for parolees, MS releasees, and probationers. Halfway house staff conjecture that, because this zip code is primarily an industrial area, nearly all of the supervised releasees who come to this zip code do so to live in the halfway house, and that, upon leaving the halfway house, they tend to reside in another area and zip code.

The East Houston neighborhood spans most of this zip code. One-third of the residents of East Houston live below the poverty level, which is 78 percent higher than the city average; the neighborhood's unemployment rate is 78 percent higher than the city average of 8 percent; and female-headed households account for 18 percent of households in the area. Six percent of East Houston housing is vacant, and 34 percent is renter-occupied. Fifty-seven percent of its residents are high school graduates, which is 20 percent lower than the city average of 70 percent. The population in this neighborhood is 70 percent non-Hispanic black, 23 percent Hispanic, 6 percent non-Hispanic white, and 1 percent other races and ethnicities. Violent crimes in this neighborhood are 19.4 per 1,000 residents, or 59 percent more than the city average (12.2 per 1,000 residents). Property crimes are 47.8 per 1,000 residents, 22 percent lower than the city average of 61.6. The drug crime rate in East Houston is 6.2 crimes per 1,000 residents, 19 percent higher than the city average.

Third Ward and MacGregor (Zip Code: 77004). In 2001, 216 supervised releasees returned to the zip code 77004 (population 29,460), at a rate of approximately 7.3 releasees per 1,000 residents (figure 7.4). The vast majority of this zip code is covered by the Third Ward/MacGregor neighborhoods. ${ }^{189}$ 
The Third Ward is by far the most disadvantaged of the seven neighborhoods described here: 38 percent of its residents live below the poverty level, which is 102 percent higher than the city average; the neighborhood has a 39 percent unemployment rate, which is 410 percent higher than the city average; and female-headed households account for 16 percent of its households. Eighteen percent of Third Ward housing is vacant, and 64 percent is renter-occupied. Fifty-six percent of its residents are high school graduates, which is 21 percent lower than the city average of 70 percent. The population in the Third Ward neighborhood is 79 percent non-Hispanic black, 10 percent Hispanic, 7 percent non-Hispanic white, and 4 percent other races and ethnicities. With regard to crime, the Third Ward experienced violent crime at a rate of 23.9 crimes per 1,000 residents, which is 96 percent higher than the city average of 12.2. The property crime rate occurred at a rate of 25.5 , which is 59 percent lower than the city average of 61.6. The Third Ward's drug crime rate is $25.5,390.4$ percent higher than the city average of 5.2.

The MacGregor neighborhood, which is the other part of the 77004 zip code area, is quite different from the Third Ward. Proportionally fewer persons live below the poverty level and proportionally fewer residents are unemployed; crime rates are lower; and the percentage of high school graduates exceeds the city average by 20 percent. Twenty-six percent of MacGregor residents live below the poverty level, 8 percent are unemployed, and 11 percent of its households are female-headed households. Thirteen percent of MacGregor housing is vacant, and 49 percent is renter-occupied housing. The MacGregor population is 80 percent non-Hispanic black, 9 percent non-Hispanic white, 5 percent Hispanic, and 6 percent other races and ethnicities. The violent crime rate is 14.0 crimes per 1,000 residents, 14.8 percent higher than the citywide rate of 12.2. The property crime rate is $26.2,57$ percent lower than the citywide rate of 61.6 . At the same time, the drug crime rate is 8.9 crimes per 1,000 residents, 71 percent higher than the city average of 5.2 .

Kashmere Gardens (Zip Code: 77026). In 2001, 207 supervised releasees returned to zip code 77026 (population 27,593), at a rate of 7.5 releasees per 1,000 residents (figure 7.4). Most of this zip code falls in the Kashmere Gardens neighborhood, which has a total population of 11,286. Thirty-seven percent of this neighborhood's residents live below the poverty level ( 95 percent higher than the city average). The neighborhood has a 15 percent unemployment rate, and women head 14 percent of the neighborhood's households. Vacant housing is 46 percent higher than the city average, but renter-occupied housing is the same as the city average of 50 percent. Fifty-two percent of Kashmere Garden residents are high school graduates, and the population in this area is almost entirely non-white ( 85 percent are non-Hispanic black). This neighborhood has the highest crime rate of the seven neighborhoods described here: the violent crime rate is 57.6 per 1,000 residents, which is 372 percent higher than the city average of 12.2; the property crime rate is 36.4 per 1,000 residents, 41 percent lower than the city average of 61.6; and the drug crime rate is 36.4 crimes per 1,000 residents, 600 percent higher than the city average of 5.2. 
East Little York/Homestead and Trinity/Houston Gardens (Zip Code 77016). In 2001, 196 supervised releasees returned to zip code 77016 (population 29,753), at a rate of 6.6 releasees per 1,000 residents (figure 7.4). Most of this zip code spans the East Little York/Homestead and Trinity/Houston Gardens neighborhoods. One-quarter of the residents of East Little York/Homestead live below the poverty level, which is 30 percent higher than the city average; the neighborhood's unemployment rate is 42 percent higher than the city average of almost 8 percent; and female-headed households account for 12 percent of households in the area. Five percent of this neighborhood's housing is vacant, and 22 percent is renter-occupied. Sixty-six percent of its residents are high school graduates. The population in this neighborhood is 83 percent non-Hispanic black, 14 percent Hispanic, 2 percent non-Hispanic white, and 1 percent other races and ethnicities. The violent crime rate in this community is 11.1 crimes per 1,000 residents, lower than the city average by 10 percent. The property crime rate is 20.1 per 1,000 residents, 67 percent lower than the citywide rate of 61.6. The drug crime rate in Little York/Homestead is 6.0 crimes per 1,000 residents, 15 percent higher than the city average.

The crime rate in the Trinity/Houston Gardens neighborhood is nearly two times that of East Little York/Homestead, and its residents are poorer and less educated. One-third of its residents live below the poverty level, which is 77 percent higher than the city average; the neighborhood's unemployment rate is 122 percent higher than the city average of 8 percent; and female-headed households account for 12 percent of households in the area. Eleven percent of this neighborhood's housing is vacant, and 35 percent is renter-occupied. Fifty-six percent of its residents are high school graduates. The population in this neighborhood is 81 percent nonHispanic black, 16 percent Hispanic, 2 percent non-Hispanic white, and 1 percent other races and ethnicities. Violent crimes in this neighborhood are 20.3 per 1,000 residents, 66 percent above the city average. The property crime rate is 40.6 per 1,000 residents, 34 percent lower than the citywide property crime rate. The drug crime rate in Trinity/Houston Gardens is 14.1 crimes per 1,000 residents, 171 percent higher than the city average of 5.2.

\section{Services for Returning Prisoners in Houston Neighborhoods}

The profiles of these seven neighborhoods suggest that they contain some of the most disadvantaged areas in the city, with the fewest economic and human capital resources. Perhaps it is not surprising that these neighborhoods are home to more returning supervised releasees, and potentially other returning prisoners; but these profiles raise important policy questions about the ability of these neighborhoods both to insulate against the potential negative impact of returning prisoners and to provide resources to these ex-prisoners. Adding to the challenges faced by these neighborhoods, as shown in figure 7.12, few of the organizations that provide ex-prisoner services - such as employment, housing, substance abuse treatment, or some combination of these support services - are located in and around the neighborhoods that are home to the most returning supervised releasees. ${ }^{190}$ Our inventory, which may not include the universe of services for returning prisoners in the city, nonetheless identifies few services located in or near four of 
the five zip codes with large numbers of returning prisoners (figure 7.13). Only the zip code 77004 (MacGregor and Third Ward) is located near a substantial number and variety of services. For the majority of these areas, then, services are located some distance away. It is not known whether prisoners returning to Houston are aware of the social services in the city, the extent to which they already use them, and whether they have the means to make use of them. For example, transportation issues and costs of services may be barriers to taking advantage of programs and assistance that might aid the reintegration process.

Figure 7.12. Social services for Houston's high-return neighborhoods, 2001

\begin{tabular}{lcll}
\hline Community & \multicolumn{2}{l}{$\begin{array}{l}\text { Number and percent } \\
\text { of social service } \\
\text { providers }\end{array}$} & Type of social service \\
\hline Alief & 1 & $(2.0 \%)$ & Employment (1) \\
Third Ward & 4 & $(8.0 \%)$ & Substance abuse treatment (4)
\end{tabular}

Source: Urban Institute analysis of 2001 TDCJ data and Elycia Daniel, Sam Houston State University.

Figure 7.13. Percentage of supervised releasees and services by Houston neighborhoods, 2001

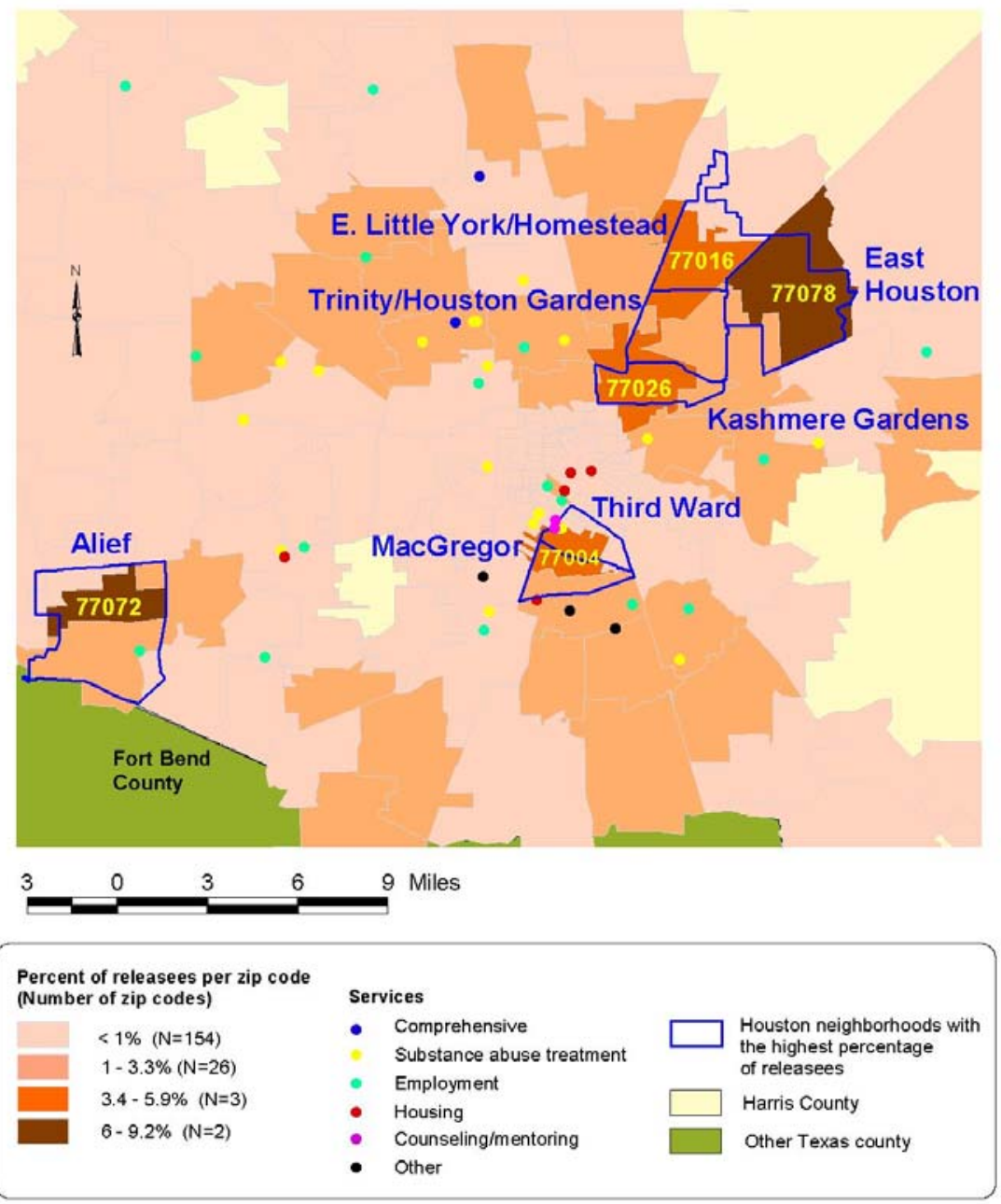

Source: Urban Institute analysis of 2001 TDCJ data and Elycia Daniel, Sam Houston State University. 


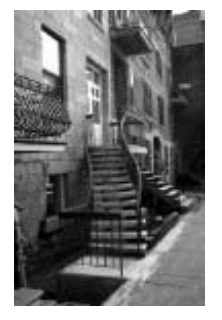

\section{CHAPTER 8 Conclusion}

\section{HIGHLIGHTS}

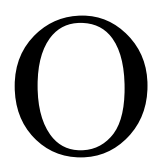

ver the past quarter-century, the growth in prison populations nationwide has translated into more and more people being released from prison and reentering society. The state of Texas has experienced similar incarceration and release trends, but it has far exceeded the nation's rate of growth. Thus, Texas faces the heightened reentry challenges that accompany such growth. Between 1980 and 2002, the Texas prison population increased more than fivefold. This growth is attributable primarily to prisoners spending longer periods of time incarcerated, mostly as a result of declining approvals for parole but also due to the meting out of longer sentences combined with legislation requiring most felons to serve a greater percentage of their sentence. Rising admissions also increased the state corrections population. Admissions grew primarily as a result of an increase in drug and violent crime arrests and felony convictions.

The number of people released from Texas correctional facilities reflects these rising admissions and population trends: in 2001, Texas prisons and state jails released 55,183 prisoners, an increase of 419 percent from 1980, when 10,636 prisoners were released. The majority of prisoners released in 2001 were male ( 86 percent), and the largest share was black (44 percent). Almost two-thirds were between 20 and 40 years old at the time of their release, with the median age at release being 34. Over one-third had been serving time for drug offenses; property offenses were the next largest share. Prisoners released in 2001 served an average of 3.4 years. State prisoners served, on average, 4.6 years ( 47 percent of their sentence), while confinees served, on average, 11 months - nearly 100 percent of their sentence.

The share of prisoners released through a decision by the Board of Pardons and Paroles or a judge (discretionary means) has fallen sharply over the past 14 years, from 75 percent in 1988 to 38 percent in 2002. Thus, in 2002, over half (62 percent) of Texas's prisoners were released through nondiscretionary means such as expiration of sentence or nondiscretionary mandatory supervision release. This shift from discretionary to mandatory release mechanisms has consequences for life after prison because mandatory releases do not require prisoners to 
appear before a parole board or other authority to be reviewed or to present a home or employment plan for after their release.

Returning prisoners in Texas have many needs as they begin the process of reintegration, and the likelihood of recidivism is high. Years of incarceration for a felony offense, combined with significant substance abuse issues, do not bode well for maintaining crime-free lifestyles, and they can also create barriers to employment. Programs, such as Project RIO, that offer jobreadiness assistance to prisoners and provide economic incentives to employers who hire exfelons may aid in the reintegration process. InnerChange Freedom Initiative (IFI), a faith-based intervention program providing vocational and life skills programs within the prison, also holds promise as an effective means of preparing prisoners for successful reentry.

Of prisoners released to parole and mandatory supervision, the largest share (23 percent, or 5,823 ) returned to Houston (local data were unavailable for other prisoners). Nearly a quarter (26 percent) of these released prisoners returned to just five of Houston's zip codes that are largely encompassed by seven neighborhoods: Alief (77072), East Houston (77078), Third Ward and MacGregor (77004), Trinity/Houston Gardens and Kashmere Gardens (77026), and East Little York/Homestead and Trinity/Houston Gardens (77016). Most of these neighborhoods are also characterized by high levels of poverty and other measures of disadvantage, and one of them, Alief, received 538 parolees and mandatory supervision releasees in 2001-more than the number that returned to most counties in Texas. East Houston received the second largest number of supervised releasees (348), which may be explained by the halfway house located in this community. Only a handful of services for ex-prisoners are located within or in close proximity to neighborhoods with high rates of returns, raising the question of whether state prisoners returning to Houston are able to access these resources.

This report can only provide limited findings on program participation by prisoners since many TDCJ programs do not report participation rates. In addition, calculations based on participation and admission rates may count more than once prisoners who participate in multiple programs. Still, the data that exist indicate that almost all prisoners have work assignments and, of potential participants, nearly half took part in education programs, more than a third received vocational or work-readiness assistance, and at least four percent were admitted to drug treatment programs. The impact of Texas's current budget deficit on these and other programs is unclear, but the potential of a significant negative impact exists. Although the state is expanding its programs by using funds from the federal Serious and Violent Offender Reentry Initiative to develop a reentry program for administrative segregation prisoners, this program will serve only a small proportion of prisoners who are dispersed across the state. These programs are, however, important given that some neighborhoods in Houston and other major cities are burdened with challenges in accommodating returning prisoners and providing services to promote their successful reintegration. 


\section{UNANSWERED QUESTIONS}

This report represents the first stage of our research on reentry in Texas and raises a number of questions that will be answered in later phases of our study. While we know much from our analysis of a cohort of released prisoners in Texas, there is much more to be learned. Such additional knowledge can provide valuable guidance to practitioners and policymakers as they prepare to expand reentry efforts in the state.

We know, for example, that the largest share of prisoners released in Texas return to Houston and that returning prisoners are even more concentrated within a few communities in the city. An examination of demographic data for these areas indicates that they are economically disadvantaged compared with the city averages. What we do not know from this research, however, is how these community characteristics might affect individual postrelease outcomes. For example, are released prisoners returning to high-crime areas more likely to recidivate than those returning to areas in which the crime rate is closer to the city average?

Very little is known about the family circumstances of released prisoners or about the role that family and other peer and interpersonal relationships play in either facilitating or preventing recidivism. This information would be useful in developing the content of family reunification programs both behind bars and on the outside. It could also help guide counseling efforts aimed at encouraging ex-prisoners to establish or renew relationships with prosocial, rather than antisocial, peers.

In addition, we do not know much about the different types of reentry challenges that different populations might face. For example, youthful ex-prisoners are likely to have different issues and challenges than their older counterparts. Similarly, employment issues are probably different for those who have served long prison terms than for those whose terms were brief. And reentry challenges for women, who often have different and more pressing family issues than men, are likely to differ from those of men. Identifying the different needs for subpopulations of returning prisoners will aid in effective program design, avoiding the "one size fits all" model in favor of one that targets individuals' needs.

\section{FUTURE RESEARCH}

As mentioned earlier, this report is the first product of a larger study, Returning Home: Understanding the Challenges of Prisoner Reentry, which examines prisoner reentry in four states. Other components of the Returning Home Texas study-pre- and postrelease interviews with prisoners returning to Houston and postrelease interviews with ex-prisoners' families-will explore many of the unanswered questions described above. These interviews are critical to understanding the individual, family, and community circumstances affecting reentry.

Such interviews, combined with analyses of official records, will help identify needs of returning prisoners that are not currently being met, such as housing, employment, and health care. The longitudinal aspect of this study will help practitioners prioritize programs by focusing 
on some of these needs before others. For example, we may learn that for certain types of exprisoners, enrolling in an outpatient substance abuse program within the first 30 days after release is more important than finding a job. We may discover that some returning prisoners find a job too early, before they have become accustomed to life on the outside, making it difficult to keep the job while managing other pressures of reentry. Such findings can help case managers better prepare prisoners for release and support them after release.

Interviews with family members may help identify factors that have a bearing on the returning prisoner's ability to stay drug- and crime-free. For example, we may find that family support in drug rehabilitation is an important predictor of a prisoner's staying off drugs after release from prison, suggesting the expansion of drug treatment programs that include family member involvement. These family interviews will also enable us to explore the role that expectations - on the part of both the prisoner and the family member-may have on the prisoner's reintegration experience.

Returning Home also explores the role of community setting and organizations in state prisoner reentry through an assessment of local community resources, assets, and risks; analyses of community administrative and census data; interviews with community stakeholders; and focus groups with community residents. Interviews with community stakeholders will shed light on gaps in local resources available to returning state prisoners, particularly in the areas with the largest numbers of returning prisoners. Neighborhood focus groups can inform grassroots efforts to support returning prisoners (e.g., helping them find housing and jobs and offering child care services). And, by linking individual data on released prisoners to data on neighborhood indicators, we can begin to explore the influence that community characteristics have on postrelease success or failure. 


\section{RETURNING HOME RESEARCH QUESTIONS}

Returning Home's two primary research questions are: What is the experience of those being released from prison and returning home? What factors influence a released prisoner's propensity to reoffend? The first research question is primarily descriptive and qualitative in nature. We plan to document and describe the individual reentry trajectoryfrom prison release to early entry, reconnection, and full integration in society-exploring the critical stages of integration and the role of individual life events, family support, community context, and state sentencing and release policies in this trajectory. The second research question is predictive in nature and is supported by ancillary questions, including the following:

- How do individual characteristics (e.g., demographics, family, criminal history, psychological attributes, life events, health and substance abuse status, and attitudes and beliefs) affect postrelease criminal behavior?

- How does family support (emotional and financial) affect postrelease criminal behavior?

- How do in-prison experiences (both formal and informal) affect postrelease criminal behavior?

- How do an individual's postrelease supervision status and conditions of release (if any) affect postrelease criminal behavior?

- How do peer relationships affect postrelease criminal behavior?

- How do community factors (e.g., economic viability, housing availability, social service delivery, crime rates, social capital) affect postrelease criminal behavior?

We also plan to explore intermediate outcomes that represent positive postprison adjustment and that can, in turn, reduce recidivism. Examples include acquiring and maintaining a job, obtaining and paying for housing, and remaining free of substance abuse. 



\section{Notes}

${ }^{1}$ From 1977 to 2001, the number of state and federal prisoners released each year has grown from nearly 148,000 to around 630,000. The 1977 figure comes from Bureau of Justice Statistics. 2000. "Sentenced Prisoners Released from State or Federal Jurisdiction." Washington, DC: U.S. Department of Justice, Bureau of Justice Statistics. http://www.ojp.usdoj.gov/bjs/dtdata.htm\#state prisoners. (Accessed November 6, 2003.) The 2001 figure comes from Paige M. Harrison and Jennifer C. Karberg. 2003. Prison and Jail Prisoners at Midyear 2002. Washington, DC: U.S. Department of Justice, Bureau of Statistics. http://www.ojp.usdoj.gov/bjs/pub/pdf/pjim02.pdf. (Accessed November 6, 2003.)

2 James Lynch and William Sabol. 2001. "Prisoner Reentry in Perspective." Crime Policy Report, vol. 3. Washington, DC: Urban Institute Press.

3 James Austin. 2001. "Prisoner Reentry: Current Trends, Practices, and Issues." Crime and Delinquency 47(3): 314-34; Ted M. Hammett, Cheryl Roberts, and Sofia Kennedy. 2001. "Health-Related Issues in Prisoner Reentry." Crime and Delinquency 47(3): 390-409; Lynch and Sabol. 2001. "Prisoner Reentry in Perspective."

${ }^{4}$ For an in-depth discussion of prisoner reentry nationwide, see Jeremy Travis, Amy Solomon, and Michelle Waul. 2001. From Prison to Home: The Dimensions and Consequences of Prisoner Reentry. Washington, DC: Urban Institute Press.

${ }^{5}$ Lynch and Sabol. 2001. "Prisoner Reentry in Perspective."

${ }^{6}$ Ibid.

${ }^{7}$ Criminal Justice Policy Council. 2003. "State Incarceration.” In Statistical Tables: State Incarceration. Austin, TX: Criminal Justice Policy Council; Paige Harrison. 2000. Sentenced Prisoners Released from State or Federal Jurisdiction. Washington, DC: U.S. Department of Justice, Office of Justice Programs.

${ }^{8}$ Urban Institute analysis of 2001 data provided by the Texas Department of Criminal Justice. Statistics on where released Texas prisoners returned are based on cases for which state information was available $(55,156$ of 55,182$)$. Of the 55,156 cases for which we had state information, county information was available for 54,645 releasees. We then used mapping software to analyze the geographic distribution of those prisoners returning to Harris County; of the 14,129 prisoners returning to Harris County, 6,594 (47 percent) had viable zip codes identified by our mapping software.

${ }^{9}$ Office of Justice Programs. 2003. State Activities and Resources: Texas. Washington, DC: U.S. Department of Justice, Office of Justice Programs. http://www.ojp.usdoj.gov/reentry/sar/tx.html. (Accessed October 26, 2003.)

${ }^{10}$ Peter Finn. 1988. “Texas's Project RIO.” Program in Focus, p. 3. Washington, DC: U.S. Department of Justice, Office of Justice Programs, National Institute of Justice.

${ }^{11}$ State Jail Division. 2002. "A New Corrections Initiative for Texas." Austin: Texas Department of Criminal Justice, State Jail Division. http://www.tdcj.state.tx.us/publications/state-jail/SJD-new-corrections-initiative.PDF. (Accessed January 2, 2004.)

${ }^{12}$ The information described in this section is based on the following three sources: (1) Paul Hudson. 1998. The State Jail System Today. Austin, TX: Criminal Justice Policy Council, September. (2) State Jail Division. 2003. "The State Jail System—A New Corrections Initiative for Texas." Austin: Texas Department of Criminal Justice, State Jail Division. http://www.tdcj.state.tx.us/statejail/stjailsytembroc.htm. (Accessed November 26, 2003.) (3) Criminal Justice Policy Council. 2003. "State Jail Releases, Fiscal Years 1996-2002." In Statistical Tables: Parole and Time Served. Austin, TX: Criminal Justice Policy Council.

${ }^{13}$ Between 1925 and 1973, the per capita rate of imprisonment in the United States remained relatively constant, at about 110 per 100,000 residents. Since 1973, however, the rate of imprisonment has been steadily increasing each year. (See Al Blumstein and Allen J. Beck. 1999. "Population Growth in U.S. 
Prisons, 1980-1996." In Prisons, edited by Michael Tonry and Joan Petersilia (26):361-426. Chicago: University of Chicago Press.) By year-end 2001, the number of sentenced prisoners per 100,000 U.S. residents was 470 - more than four times the rate of imprisonment that had been maintained during the early part of the 20th century. (See Paige Harrison and Allen J. Beck. 2002. "Prisoners in 2001." Bureau of Justice Statistics Bulletin. Washington, DC: U.S. Department of Justice, Bureau of Justice Statistics.)

${ }^{14}$ The fiscal year 1980 statistic is based on the total number of felons in state prisons. (Source: Texas Department of Correction. 1980. 1980 Fiscal Year Statistical Report. Huntsville: Texas Department of Correction, Research and Development.) The fiscal year 2002 statistic is based on the total number of felons in state prisons, state jails, Substance Abuse Felony Punishment programs, boot camps, and county jails. Please note that state jails, Substance Abuse Felony Punishment programs, and boot camps were not in existence in fiscal year 1980. (Sources: Criminal Justice Policy Council. 2003. "TDCJ State Incarcerated Population, Fiscal Years 1988 to 2002.” In Statistical Tables: State Incarceration, p. 7. Austin, TX: Criminal Justice Policy Council; Criminal Justice Policy Council. 2003. "Prison Felons in County Jails, Fiscal Years 1992 to 2002.” In Statistical Tables: County Jail, p. 2. Austin, TX: Criminal Justice Policy Council.)

${ }^{15}$ Data sources include the Texas Department of Criminal Justice, Criminal Justice Policy Council, and the U.S. Census Bureau.

${ }^{16}$ Paige M. Harrison and Allen J. Beck. 2003. "Prisoners in 2002." Bureau of Justice Statistics Bulletin, p. 1. Washington, DC: U.S. Department of Justice, Bureau of Justice Statistics.

${ }^{17}$ Texas Department of Criminal Justice. 2003. "Unit Directory." Austin: Texas Department of Criminal Justice. http://www.tdcj.state.tx.us/directory/unit-profiles/dir-units-list.htm. (Accessed March 19, 2003.) ${ }^{18}$ Ibid.

${ }^{19}$ Texas Department of Criminal Justice. 2000. Closing of a Millennium: Reviewing the Past Decade, p. 8. Huntsville: Texas Department of Criminal Justice, Financial Services Division.

${ }^{20}$ For 1990 data, see Texas Department of Criminal Justice. 2000. Closing of a Millennium: Reviewing the Past Decade, p. 8. Huntsville: Texas Department of Criminal Justice, Financial Services Division. For 2000 data, see Criminal Justice Policy Council. 1999. "Operating and Construction Expenditures in the Texas Department of Criminal Justice, Fiscal Years 1988 to 2002." In Statistical Tables: Funding and Cost per Day, p. 6. Austin: Texas Criminal Justice Policy Council.

${ }^{21}$ Sidra L. Gifford. 2002. "Justice Expenditures and Employment in the United States, 1999." Bureau of Justice Statistics Bulletin, p. 5. Washington, DC: U.S. Department of Justice, Bureau of Justice Statistics.

${ }^{22}$ Center for Public Priorities. 2003. "Texas Criminal Justice/Corrections Facts." http://www.cppp.org/products/fastfacts/crimjust.html. (Accessed July 27, 2003.)

${ }^{23}$ The information presented in this paragraph comes from the following source unless otherwise specified: State Research Center. 1994. "Chronology of Texas Prison Reform 1972 to 1994,” p. 5. Austin, TX: State Research Center.

${ }^{24}$ Under a settlement that was part of a lawsuit, Ruiz v. Estelle, TDCJ was prohibited from exceeding 95 percent of facilities' bed capacities as of 1985; thus, TDCJ housed prisoners in county facilities until beds became available. Due to the persistent reliance on county beds, however, 12 counties sued TDCJ, and in 1991 , the court ordered TDCJ to pay fines for state inmates held in the county jail that accrued to over $\$ 667$ million between 1990 and 1999. As a result, legislation was passed that required TDCJ to house state inmates in prison at least 45 days after their commitment paperwork was filed.

${ }^{25}$ Crime is measured by the number of violent and property crimes reported to the police and provided by the FBI's Uniform Crime Reporting System Part I Index of violent and property offenses. Violent index crimes include murder, nonnegligent manslaughter, forcible rape, robbery, and aggravated assault. It is referred to here as "serious" because it does not include non-aggravated assaults and other less serious violent offenses. Property index crimes include burglary, larceny-theft, and motor vehicle theft. Data for other crimes, most notably drug crimes, are not available. The information presented in this section comes from the following source unless otherwise specified: Criminal Justice Policy Council. 2002. Statistical Tables: Crime in Texas. Austin, TX: Criminal Justice Policy Council.

${ }^{26}$ Criminal Justice Policy Council. 2002. "Adult Population and Arrests in Texas, Fiscal Years 1990 to 2001.” In Statistical Tables: Arrests, p. 1. Austin, TX: Criminal Justice Policy Council.

${ }^{27}$ Violent crime and admissions for violent offenses are defined similarly, but admissions for violent crimes encompass more violent offense types than the definition for violent crimes and arrests do. Specifically, violent offenses for admissions include homicide, kidnapping, sexual assault, robbery, and assault. Violent 
crime is defined in the same way except that it does not include non-aggravated assaults and sexual assaults. This difference in definitions is likely to produce notable differences in the two resulting statistics since non-aggravated assault is generally a commonly occuring offense. Still, a comparison of the trends is important in developing a general picture of the relevant patterns occurring in Texas.

${ }^{28}$ The definitions of property crimes and property admissions both include burglary, larceny, theft, and motor vehicle theft. Unlike property admissions, property crimes do not include arson, forgery/counterfeit, and fraud (data on crimes related to these offenses were unavailable); and because arrests for these offense types are likely to occur in substantial numbers, the comparability between property crime trends and property arrest and admission trends is reduced.

${ }^{29}$ Arrest statistics presented here are for adults 17 years old or older because nearly all the TDCJ prison population is made up of individuals age 17 and older. The Urban Institute's analysis of TDCJ data revealed that no prisoners reentering the community in 2001 were younger than 17 years of age. However, people as young as 14 years old can be tried as adults in Texas. (Source: Public Broadcasting Service.

"Frontline: Juvenile Justice Facts and Stats." http://www.pbs.org/wgbh/pages/frontline/shows/juvenile/stats/states.html. [Accessed October 13, 2003.]) ${ }^{30}$ These data come from Texas Department of Public Safety's Texas Arrest Data provided in their annual Texas Crime Report (years 1988 to 2001).

${ }^{31}$ Violent arrests include murder, nonnegligent manslaughter, forcible rape, robbery, aggravated assault, and other assaults. Violent arrests include all violent offenses - not only violent offenses as defined by FBI's Uniform Crime Reports - in order to increase the comparability of the arrest trends to admission trends. These two categories are defined in the same way violent admissions also include kidnapping and all sexual assaults (not just forcible rape); this difference is expected to have minimal impact on the findings since few arrests for kidnapping and other sexual assaults are expected to take place.

${ }^{32}$ Drug arrests and admissions are defined in the same way: they both include drug offenses related to the possession or distribution of drugs.

${ }^{33}$ Property arrests and property admissions are defined in the same way; they both include burglary, larceny, theft, motor vehicle theft, arson, forgery/counterfeit, and fraud. Property crimes, however, do not include arson, forgery/counterfeit, and fraud; and because arrests for these offense types are likely to occur in substantial numbers, the comparability between property crime trends and property arrest and admission trends is reduced.

${ }^{34}$ The American Civil Liberties Union. 2002. Too Far Off Task. Austin, TX: The American Civil Liberties Union of Texas.

${ }^{35} \mathrm{Ibid}$.

${ }^{36}$ During the mid-1990s to 2002, a greater percentage of cases received deferred adjudication dispositions for all offense types except driving while intoxicated, which had stable conviction rates. The Criminal Justice Policy Council defines deferred adjudication as "a postponement of entering a finding of guilt, where the offender undergoes a term of community supervision that, if completed successfully, will prevent a final conviction from appearing on the offender's record." (Source: Criminal Justice Policy Council. 2003. "Total Adult Convictions and Deferred Adjudications for All Felony Offenses, Fiscal Years 19882002.” In Statistical Tables: Court Convictions. Austin, TX: Criminal Justice Policy Council.)

${ }^{37}$ The information provided in this section comes from Criminal Justice Policy Council. 2003. Statistical Tables: State Incarceration. Austin, TX: Criminal Justice Policy Council.

${ }^{38}$ Unless otherwise specified, the information provided in this section comes from Criminal Justice Policy Council. 2003. Statistical Tables: Parole and Time Served. Austin, TX: Criminal Justice Policy Council.

${ }^{39}$ The source for national information described in this paragraph is Timothy A. Hughes, Doris James Wilson, and Allen J. Beck. 2001. "Trends in State Parole, 1990-2000." Bureau of Justice Statistics Special Report. Washington, DC: U.S. Department of Justice, Bureau of Justice Statistics.

${ }^{40}$ The length of a prisoner's sentence, which is the term of imprisonment meted out by the court, does not necessarily correspond to the actual time served in prison (i.e., prisoners usually serve less time than their court-ordered sentence lengths).

${ }^{41}$ The Criminal Justice Policy Council explains that nonviolent offenders "include those convicted of all property offenses (except first degree burglary of a habitation), DWI, drug offenses, motor vehicle theft, and other miscellaneous offenses." The Criminal Justice Policy Council defines violent offenders as "offenders convicted of: homicide, kidnapping, sexual assault, robbery, assault, burglary of a habitat with the intent to commit a felony other than theft, indecency with a child, and offenders convicted of a $3 \mathrm{~g}$ 
offense (which are aggravated offenses as defined by Article 42.12, Section $3 g$ of the Texas Code of Criminal Procedures)." According to the Criminal Justice Policy Council, aggravated crimes are the most serious violent offenses and include "capital murder, murder, aggravated sexual assault, aggravated kidnapping, aggravated robbery, indecency with a child, sexual assault, use of a deadly weapon, and any other offense with an affirmative weapon finding." See "Time Served in Prison for All Release Types: Violent Offenders, Fiscal Years 1988 to 2002.” Austin, TX: Criminal Justice Policy Council.

${ }^{42}$ There are several reasons for these changes in sentence length. From 1988 to 1994, the number of convicted felons in county jails awaiting transfer to TDCJ facilities grew significantly, peaking at 26,100 felons in 1993. Many of these felons were released from county jails under parole in absentia and were never admitted to prison. These prisoners often had shorter sentences; consequently, the average sentence length of those admitted to prison grew. In 1995, when TDCJ had enough bed space to accommodate most felons ready for transfer to TDCJ, the sentence length dropped dramatically. Although prisoners received increasingly longer sentences between 1998 and 2002, the growing population of confinees (less serious offenders) received shorter sentences and thereby moderated the overall length of sentence for all prisoners. ${ }^{43}$ For this analysis, the sentence length of confinees is used also as their time served because time-served data are not available. This approximation is estimated to be accurate in all but 2 percent of confinee releases who did not complete their entire sentence as a result of shock probation.

${ }^{44}$ Sentencing judges can expedite a prisoner's release through shock probation, which allows him to complete his sentence in the community while supervised under Regular Felony Probation and while complying with certain requirements. Confinees are eligible for shock probation at any time during their incarceration while state prisoners are eligible only during their first 180 days in prison. Prisoners may be considered for shock probation if they are eligible for Regular Felony Probation or State Felony Jail Probation, are serving a sentence of ten years or less, and have not been incarcerated previously for a felony offense.

${ }^{45}$ Paula M. Ditton and Doris James Wilson. 1999. "Truth in Sentencing in State Prisons." Bureau of Justice Statistics Special Report. Washington, DC: U.S. Department of Justice, Bureau of Justice Statistics.

${ }^{46}$ For a complete listing of the required percentage of time served for each offender type and eligibility requirements, refer to the Texas Department of Criminal Justice website, http://www.tdcj.state.tx.us/publications/parole/parole_in tx/pit-par-man-sup.htm. (Accessed July 9, 2003.) A Criminal Justice Policy Council report explains that a primary goal guiding some major prisoner-related changes in the 1990s was "to increase the percent of sentence served in prison for violent offenders." (Source: Michelle Munson. 2000. "Goal Met: Violent Offenders in Texas Are Serving a Higher Percentage of Their Prison Sentences." Austin, TX: Criminal Justice Policy Council.)

${ }^{47}$ In 1987, the legislature lowered parole eligibility from one-third of a prisoner's sentence length to onequarter in response to an increasing backlog of TDCJ prisoners in county jail facilities. (Source: Senate Research Center. 1994. "Chronology of Texas Prison Reform 1972 to 1994,” p. 8. Austin, TX: Senate Research Center.)

${ }^{48}$ Paula M. Ditton and Doris James Wilson. 1999. "Truth in Sentencing in State Prisons.” Bureau of Justice Statistics Special Report, p. 2. Washington, DC: U.S. Department of Justice, Bureau of Justice Statistics.

${ }^{49}$ Criminal Justice Policy Council. 2003. Statistical Tables: Parole and Time Served. Austin, TX: Criminal Justice Policy Council.

${ }^{50}$ Between 1993 and 2003, the percentage of sentence served increased from 40 to 75 percent for prisoners who had committed violent offenses, from 43 to 81 percent for those who committed aggravated offenses, and from 24 to 52 percent for those who committed nonviolent offenses.

${ }^{51}$ Unless otherwise specified, the information provided in this section comes from Criminal Justice Policy Council. 2003. "Parole Approval Rates, Fiscal Years 1988-2002." In Statistical Tables: Parole and Time Served, p.1. Austin, TX: Criminal Justice Policy Council.

${ }^{52}$ The number of parole-eligible releases is equal to all TDCJ releases minus confinees and death-sentenced prisoners because they are ineligible for parole. In 1988, there were 33,428 TDCJ releases, no confinees, and 258 death-row prisoners; in 2002, there were 58,949 TDCJ releases, 21,325 confinee releases, and 449 death-row prisoners.

${ }_{53}$ As part of most legislative sessions since 1987, Texas legislators have rendered some violent and aggravated offenders ineligible for good-conduct time. Also, when creating the state jail felon category, legislators decided to make confinees ineligible for good-conduct time given that they would receive relatively short sentences. 
54 Texas Department of Criminal Justice. 2003. "General Information Guide for Families: Good-Conduct
Time.” http://www.tdcj.state.tx.us/publications/offender_family_guide/offguide-goodcondct.htm. (Accessed December 31, 2003.)

${ }^{55}$ As of September 1, 1996, the Board of Pardons and Paroles assumed discretion over whether a prisoner receives earned good-behavior credits. Prior to 1996, all eligible prisoners were released automatically to mandatory supervision. The Board approves approximately half of the cases considered.

${ }^{56}$ Unless otherwise specified, all information in this chapter draws from a TDCJ data file containing information about those prisoners released from TDCJ custody to the community in 2001 or from Criminal Justice Policy Council statistical tables and reports available on the agency's website at http://www.cjpc.state.tx.us/.

${ }^{57}$ The total number of prisoners released from TDCJ in 2001 presented in this report $(55,183)$ differs from the total number of prisoners that the Criminal Justice Policy Council (CJPC) reports to have been released from TDCJ custody in $2001(61,548)$. The likely explanation for the difference is that the cohort analyzed by the Urban Institute does not include prisoners not released from TDCJ custody to the community, including those released from TDCJ custody to the custody of another authority (such as Immigration and Naturalization Services or another correctional facility), those who died or were executed, those who escaped, or those who were released only temporarily (for such reasons as the need for medical care or to attend a relative's funeral) in 2001. The total number of prisoners who were excluded for these reasons is approximately 7,018. The fact that the cohort analyzed by CJPC was drawn from fiscal year 2001, while the cohort analyzed by the Urban Institute is drawn from calendar year 2001, may also explain part of the difference between the two statistics.

${ }^{58}$ Per conversation with TDCJ's Community Supervision and Corrections Department staff on November 26,2003 , Texas prisoners who are released to probation, parole, or mandatory supervision must remain in Texas until another state agrees to assume responsibility for supervising the prisoner in the community due to the interstate compact.

${ }^{59}$ Following the procedure employed by the Criminal Justice Policy Council, life sentences and sentences of more than 60 years are calculated as 60 -year sentences.

${ }^{60}$ Patrick Langan and David Levin. 2002. "Recidivism of Prisoners Released in 1994." Bureau of Justice Statistics Special Report. Washington, DC: U.S. Department of Justice, Bureau of Justice Statistics.

${ }^{61}$ Criminal Justice Policy Council. 2002. "Two- and Three-Year Recidivism Rates for Offenders Released from Prison.” In Statistical Tables: Recidivism Rates, p. 1. Austin, TX: Criminal Justice Policy Council.

${ }^{62}$ Criminal Justice Policy Council. 2002. "Recidivism Rates of Confinees." In Statistical Tables: Recidivism Rates, p. 7. Austin, TX: Criminal Justice Policy Council.

${ }^{63}$ The reasons for reincarceration (technical violations of supervision conditions or new crimes) are not available.

${ }^{64}$ Laura M. Maruschak and Allen J. Beck. 2001. "Medical Problems of Prisoners, 1997." Bureau of Justice Statistics Special Report. Washington, DC: U.S. Department of Justice, Bureau of Justice Statistics.

${ }^{65} \mathrm{CJPC}$ defined elderly as age 55 and older because "Offenders in prison generally have the health problems of people ten years older in the general population; therefore age 55 is considered elderly in the prison population." CJPC found that elderly prisoners are being admitted in higher numbers and also tend to have longer sentences and therefore are incarcerated for longer periods than the average prisoner. (Source: Criminal Justice Policy Council. 2003. "Elderly Prisoners (Ages 55 \& Older) in the Prison Population." In Statistical Tables: Programs and Special Populations. Austin, TX: Criminal Justice Policy Council.)

${ }^{66}$ Texas Department of Criminal Justice. 1999. Fiscal Year 2000 Agency Budget, p. 4. Austin: Texas Department of Criminal Justice.

${ }^{67}$ Laura M. Maruschak. 2001. "HIV in Prisons, 2000.” Bureau of Justice Statistics Bulletin, p. 1. Washington, DC: U.S. Department of Justice.

${ }^{68}$ Ibid.

${ }^{69}$ UTMB manages the administration of medication at 80 percent of all TDCJ facilities; Texas Tech University manages the rest.

${ }^{70}$ Mike Ward and Bill Bishop. 2001. "A New HIV: Some Convicts Back in Free World with Altered Virus Strain." Austin American-Statesman, December 17.

${ }^{71}$ TDCJ does not maintain comprehensive, electronically accessible data on the health care needs of and range of services available to all prisoners under its supervision. 


\footnotetext{
${ }^{72}$ For more information about the health needs of returning prisoners nationwide, see National Commission on Correctional Health Care. 2002. The Health Status of Soon-to-Be-Released Inmates: A Report to Congress, volume 1. Chicago: National Commission on Correctional Health Care.

${ }^{73}$ These totals do not include those prisoners who have a mental health issue but declined treatment, do not meet the requirements for active case management, or are not exhibiting any symptoms currently although they have experienced a mental illness previously. (Source: Criminal Justice Policy Council. 2001. "Texas Department of Criminal Justice - Institutional Division Mental Health Caseload 1988 and 1998." In Statistical Tables: Programs and Special Populations, p. 4. Austin, TX: Criminal Justice Policy Council.) ${ }^{74}$ Ibid.

${ }^{75}$ Texas Department of Criminal Justice. 1999. Fiscal Year 2000 Agency Budget, p. 4. Austin: Texas Department of Criminal Justice.

${ }^{76}$ All information provided in this paragraph is based on the following source: Criminal Justice Policy Council. 2002. "Overview of the Enhanced Mental Health Services Initiative," p. 6. Austin, TX: Criminal Justice Policy Council.

${ }^{77}$ See Douglas Lipton, Robert Martinson, and Judith Wilks. 1975. The Effectiveness of Correctional Treatment: A Survey of Treatment Evaluation Studies. New York: Praeger; Robert Martinson. 1974. "What Works? Questions and Answers about Prison Reform." The Public Interest (35): 22-45; Lee Sechrest, Susan White, and Elizabeth Brown, eds. 1979. The Rehabilitation of Criminal Offenders: Problems and Prospects. Washington, DC: National Academy of Science; David F. Greenberg. 1977. "The Correctional Effects of Corrections: A Survey of Evaluations." In Corrections and Punishment, edited by David F. Greenberg (111-148). Beverly Hills: Sage Publications; William E. Wright and Michael C. Dixon. 1977. "Community Prevention and Treatment of Juvenile Delinquents." Journal of Research in Crime and Delinquency 14(35-67): 35-67; J. Robison, and G. Smith. 1971. "The Effectiveness of Correctional Programs." Crime and Delinquency 17(1): 67-80.

${ }^{78}$ See Sarah Lawrence, Daniel Mears, Glenn Dubin, and Jeremy Travis. 2002. The Practice and Promise of Prison Programming. Research Report. Washington, DC: The Urban Institute; Gerald Gaes, Timothy S. Flanagan, Laurence L. Motiuk, and Lynn Stewart. 1999. "Adult Correctional Treatment." In Prisons, edited by Michael Tonry and Joan Petersilia (26):361-426. Chicago: University of Chicago Press; David B. Wilson, Catherine A. Gallagher, and Doris L. MacKenzie. 2000. "A Meta-Analysis of Corrections-Based Education, Vocation, and Work Programs for Adult Offenders." Journal of Research in Crime and Delinquency 37(4): 347-68; Mark Lipsey. 1999. "Can Intervention Rehabilitate Serious Delinquents?” The Annals of the American Academy 564: 142-66; Frank S. Pearson and Douglas S. Lipton. 1999. "MetaAnalytic Review of the Effectiveness of Corrections-Based Treatments for Drug Abuse." Prison Journal 79(4): 384-410; Mark W. Lipsey and David B. Wilson. 1998. "Effective Interventions for Serious Juvenile Offenders: A Synthesis of Research." In Serious and Violent Juvenile Offenders: Risk Factors and Successful Interventions, edited by Rolf Loeber and David P. Farrington (313-345). Thousand Oaks, CA: Sage Publications; Don A. Andrews, Ivan Zinger, Robert D. Hoge, James Bonta, Paul Gendreau, and Francis T. Cullen. 1990. "Does Correctional Treatment Work? A Clinically Relevant and Psychologically Informed Meta-Analysis." Criminology 28: 369-404.

${ }^{79}$ Refers to prisoners scheduled to be released in the next 12 months. Lynch and Sabol. 2001. "Prisoner Reentry in Perspective."

${ }^{80}$ Ibid.

${ }^{81}$ Bureau of Justice Statistics. 2000. Correctional Populations in the United States, 1997. Washington, DC: U.S. Department of Justice.

82 TDCJ's fiscal year 2000 budget reports that $\$ 164,952,615$ was allocated for the main categories of institutional prisoner programs. Additional TDCJ funds are devoted to other programs and services for TDCJ prisoners (such as prisoner law libraries), but the total amount of funds devoted to these purposes was unclear. WSD reports $\$ 76,430,973$ was expended for educational programs in fiscal year 2000 . The TDCJ budget totals are based on budget allocations in contrast to the Windham School District budget totals, which are based on expenditures; the expected difference between TDCJ's allocated budget and actual expenditures is expected to be minimal.

${ }_{83}^{8}$ Per conversation with Windham School District staff member on February 6, 2004.

${ }^{84}$ Ibid.

${ }^{85}$ For the other areas cut in the biennial decrease, 26 percent was due to the removal of the contract capacity bed requirements; over 21 percent was due to cuts in funding for support staff and for food,
} 
utilities, and building maintenance for housing offenders (no correctional officer positions were eliminated); and almost 18 percent involved cuts in administrative and information technology functions. (Source: Per TDCJ staff on February 20, 2004.)

${ }^{86}$ TDCJ's operating budget in fiscal year 2003 was $\$ 5,094,996,780$; it is $\$ 4,840,246,524$ in fiscal year 2004. (Source: Per TDCJ staff on February 20, 2004.)

${ }^{87}$ The number of potential participants equals 199,624 , the total on-hand population at the end of the fiscal year $2002(125,937$ state prisoners and 14,738 confinees) plus the number of prisoners released in fiscal year 2002 (37,624 state prisoners and 21,325 confinees).

${ }^{88}$ This chapter does not discuss several other TDCJ programs that target special populations, such as youthful offenders, due to space limitations; however, the programs listed represent the main universe of programs at TDCJ.

${ }^{89}$ Karl O. Haigler, Caroline Harlow, Patricia O’Connor, and Anne Campbell. 1994. 'Literacy behind Prison Walls" Washington, DC: U.S. Department of Education, National Center for Education Statistics, NCES-1994-102.

${ }^{90}$ The general population includes the noninstitutional population over the age of 18 . Caroline W. Harlow. 2003. "Education and Correctional Populations." Bureau of Justice Statistics Report, p. 2. Washington, DC: U.S. Department of Justice, Bureau of Justice Statistics.

${ }^{91}$ These data are not available for state jail felons.

${ }^{92}$ A prisoner who is functionally illiterate has an educational achievement score of less than 6.0. Educational achievement scores are calculated using the Test of Adult Basic Education (TABE). Texas Department of Criminal Justice. 2003. Texas Department of Criminal Justice Fiscal Year 2002 Statistical Report, pp. 11, 16, 24. Huntsville: Texas Department of Criminal Justice.

${ }^{93}$ Prison population includes prison, state jail, and Substance Abuse Felony Punishment facilities. Texas Department of Criminal Justice. 2002. Texas Department of Criminal Justice Fiscal Year 2002 Statistical Summary. Huntsville: Texas Department of Criminal Justice.

${ }^{94}$ Windham School District staff provided the estimate of program capacity.

${ }^{95}$ Martinez, Alma I., and Michael Eisenberg. 2000. Educational Achievement of Inmates in the Windham School District, p. i. Austin, TX: Criminal Justice Policy Council. Also, per conversation with WSD staff on February 17, 2004.

${ }^{96}$ Unless otherwise stated, all information for the Windham School District was obtained from the following report: Windham School District. 2002. Windham School District Annual Report. Huntsville: Texas Department of Criminal Justice.

${ }^{97}$ All information on the COPE program was found in Texas Board of Pardons and Paroles and Texas Department of Criminal Justice. 1998. Parole in Texas. Austin: Texas Board of Pardons and Paroles and Texas Department of Criminal Justice. http://www.tdcj.state.tx.us/publications/parole/parole_in_tx/pithome.htm. (Accessed January 2, 2004.)

${ }^{98}$ Julie Cook. 2003. Mangos to Mangos: Comparing the Cost of Juvenile and Adult Correctional Programs in Texas, p. 40. Austin, TX: Criminal Justice Policy Council.

${ }^{99}$ Jeremy Travis. 2002. "Invisible Punishment: An Instrument of Social Exclusion." In Invisible Punishment: the Collateral Consequences of Mass Imprisonment, edited by Marc Mauer and Meda Chesney-Lind, p. 22. New York: New Press.

${ }^{100}$ Bruce Western. 2003. "Incarceration, Employment and Public Policy." Paper prepared for the Third Reentry Roundtable, April 2003. http://www.njisj.org/reports/western_report.html. (Accessed August 11, 2003.)

${ }^{101}$ See figure 3.1 for a breakdown of program admission numbers for fiscal year 2003. Texas Department of Criminal Justice. 2003. Texas Department of Criminal Justice Fiscal Year 2002 Statistical Report, pp. 30-31. Huntsville: Texas Department of Criminal Justice.

${ }^{102}$ Some prisoners who participated in multiple programs may have been counted more than once in this total.

${ }^{103}$ Unless otherwise noted, information on employment programs administered in correctional facilities is obtained from Windham School District. 2002. Windham School District Annual Performance Report 2001-2002: Schools in the Texas Department of Criminal Justice, pp. 5-8. Huntsville: Texas Department of Criminal Justice; Texas Department of Criminal Justice. 2003. Texas Department of Criminal Justice Statistical Summary Fiscal Year 2002, pp. 30-31. Huntsville: Texas Department of Criminal Justice. 
${ }^{104}$ Texas Department of Criminal Justice. 2002. Windham School District Annual Performance Report 2001-2002: Schools in the Texas Department of Criminal Justice, pp. 3, 5-6. Huntsville: Texas Department of Criminal Justice.

${ }^{105}$ The selection and structure of the courses offered depends on the projected employment opportunities for prisoners and industry standards.

${ }^{106}$ Texas Department of Criminal Justice State Jail Division. 2001. “A New Corrections Initiative for Texas." Austin: Texas Department of Criminal Justice. http://www.tdcj.state.tx.us/publications/statejail/SJD-new-corrections-initiative.PDF. (Accessed November 1, 2003.)

${ }^{107}$ Information provided by the Texas Department of Criminal Justice Parole Division, Open Records Division, September 25, 2003.

${ }^{108}$ Texas Board of Pardons and Paroles. 2002. 2001-2002 Texas Board of Pardons and Paroles Annual Report, p. 157. Austin: Texas Board of Pardons and Paroles.

${ }^{109}$ Texas Work Commission Project RIO staff certifies prospective employees for the Work Opportunity Tax Credit program that provides a tax incentive to employers for hiring economically disadvantaged exoffenders.

${ }^{110}$ Alan Beck. 2000. State and Federal Prisoners Returning to the Community: Findings from the Bureau of Justice Statistics. Paper presented at the First Reentry Courts Initiative Cluster Meeting, Washington, DC, April 13, 2000. http://www.ojp.usdoj.gov/bjs/pub/pdf/sfprc.pdf. (Accessed December 30, 2003.) Also see Christopher Mumola. 1999. Substance Abuse and Treatment, State and Federal Prisoners, 1997. Bureau of Justice Statistics, Special Report. Washington, DC: U.S. Department of Justice, NCJ 172871. ${ }^{111}$ Ibid.

112 Jane Carlisle Maxwell. 1998. Substance Abuse and Crime in Texas, p. 7. Austin: Texas Commission on Alcohol and Drug Abuse.

${ }^{113}$ TDCJ reports that 281,267 prisoners attended AA, NA, or SOS programs in fiscal year 2002; given that this number is more than double the prison population as a whole, the figure clearly reflects a large number of duplicate prisoners who participated in multiple programs or on repeated occasions.

${ }^{114}$ Unless otherwise noted, all data on the IPTC, PRSAP, PRTC, and SAFP programs are drawn from Michael Eisenberg. 2003. The Second Biennial Report on the Performance of the Texas Department of Criminal Justice Rehabilitation Tier Programs. Austin, TX: Criminal Justice Policy Council.

${ }^{115}$ The CJPC reports that the success rate of the IPTC program has improved since 1994 when a more accurate screening process was put in place and when the use of intermediate sanction facilities as an alternative to reincarceration became more frequent (thereby returning fewer parolees to prison). Current completion rates are not available, however.

${ }^{116}$ In 2003, SAFP sentences were reduced from between 9 and 12 months to 6 months.

${ }^{117}$ Michael Eisenberg. 2003. The Second Biennial Report on the Performance of the Texas Department of Criminal Justice Rehabilitation Tier Programs, p. ii. Austin, TX: Criminal Justice Policy Council.

${ }^{118}$ Program components include 9 to 12 months of institutional programming, 3 months of residential programming, and 6 to 9 months of outpatient care. (Source: Criminal Justice Policy Council. 2002. "Report to the Senate Criminal Justice Interim Committee: Recidivism Rates and Issues Related to TDCJ Substance Abuse Treatment Programs, March 2002.” In Adult Correctional and Rehabilitation Programs/Recidivism, p. 8. Austin, TX: Criminal Justice Policy Council.)

${ }^{119}$ Carole Keaton Rylander. 2000. "Chapter 11: Improve Correctional Substance Abuse Treatment." Recommendations of the Texas Comptroller. http://www.e-texas.org/recommend/ch11/psc05.html. (Accessed June 5, 2003.) And see Gerald Gaes, Timothy J. Flanagan, Laurence L. Motiuk, and Lynn Stewart. 1999. "Adult Correctional Treatment." In Prisons, Criminal Justice: A Review of Research, edited by Michael Tonry and Joan Petersilia (361-426). Chicago: University of Chicago Press.

120 "The 'estimated yearly population served' is based on the average length of stay (ALS) in inpatient programs." (Source: Criminal Justice Policy Council. 2001. "Prisoner Substance Abuse Treatment Program Bed Capacity for Adult Offenders in Texas.” In Statistical Tables: Programs and Special Populations, p. 1. Austin, TX: Criminal Justice Policy Council.)

${ }^{121}$ Criminal Justice Policy Council. 2001. "Outpatient Substance Abuse Treatment and Other Programs for Adult Prisoners in Texas." In Statistical Tables: Programs and Special Populations, p. 2. Austin, TX: Criminal Justice Policy Council. 
${ }^{122}$ Criminal Justice Policy Council. 2001. "Prisoner Substance Abuse Treatment Program Bed Capacity for Adult Offenders in Texas." In Statistical Tables: Programs and Special Populations, p. 1. Austin, TX: Criminal Justice Policy Council.

${ }^{123}$ Criminal Justice Policy Council. 2001. "Outpatient Substance Abuse Treatment and Other Programs for Adult Prisoners in Texas." In Statistical Tables: Programs and Special Populations, p. 2. Austin, TX: Criminal Justice Policy Council.

${ }^{124}$ Allen J. Beck. 2001. "Mental Health Treatment in State Prisons.” Bureau of Justice Statistics Special Report. Washington, DC: U.S. Department of Justice, NCJ 188215.

${ }^{125}$ The official figure for patients under mental health care in the prison population may not accurately reflect the number of prisoners suffering from mental illness. This number does not reflect undiagnosed prisoners, patients who refuse treatment, or patients with a history of mental illness who do not display symptoms and are therefore not treated. (Source: Criminal Justice Policy Council. 2001. "Texas Department of Criminal Justice-Institutional Division Mental Health Caseload, 1988 and 1998." In Statistical Tables: Programs and Special Populations, p. 4. Austin, TX: Criminal Justice Policy Council.) ${ }^{126}$ Ibid.

${ }^{127}$ Ibid.

${ }^{128}$ Mental health staff may evaluate prisoners for potential mental health problems and diagnoses of mental illness, determine which method(s) of treatment will be most effective and beneficial to prisoners, or provide access to mental health services for prisoners who send a sick call request (SCR) or an I-60. Access to services includes crisis intervention and "follow-up" appointments. Treatment may also be provided to mentally ill prisoners and can include medication. (Source: Texas Department of Criminal Justice. "Offender Handbook, 2003." Huntsville: Texas Department of Criminal Justice.)

${ }^{129}$ Texas Department of Criminal Justice. 2003. Fiscal Year 2002 Statistical Report. Huntsville: Texas Department of Criminal Justice.

${ }^{130}$ Per TDCJ staff, December 18, 2003.

${ }^{131}$ Texas Department of Criminal Justice. 2003. "Unit Directory.” Huntsville: Texas Department of Criminal Justice. http://www.tdcj.state.tx.us/directory/unit-profiles/dir-units-list.htm. (Accessed October 26, 2003.)

${ }^{132}$ In fiscal year 2002, 20,331 (16 percent) of those incarcerated in Texas prisons were incarcerated for sexual assault or a sex offense. (Source: Texas Department of Criminal Justice. 2002. Fiscal Year 2002 Statistical Report. Huntsville: Texas Department of Criminal Justice.)

${ }^{133}$ Only 5 percent of those sex offenders considered for parole in 2002 received approvals, and 91 percent of all sex offenders are ineligible for mandatory supervision. The parole approval rates for sex offenders were drawn from Criminal Justice Policy Council. 2003. "Fiscal Year 2002 Parole Approval Rates by Offense Type.” In Statistical Tables: Parole and Time Served, p. 2. Austin, TX: Criminal Justice Policy Council. The mandatory supervision restrictions for sex offenders were drawn from Michael Eisenberg. 1996. The Impact of Tougher Incarceration Policies for Sex Offenders. Austin, TX: Criminal Justice Policy Council.

${ }^{134}$ Michael Eisenberg. 2003. The Second Biennial Report on the Performance of the Texas Department of Criminal Justice Rehabilitation Tier Programs. Austin, TX: Criminal Justice Policy Council.

${ }^{135}$ Ibid.

${ }^{136}$ Byron R. Johnson and David B. Larson. 2003. "The InnerChange Freedom Initiative: A Preliminary Evaluation of a Faith-Based Prison Program." Philadelphia: University of Pennsylvania.

${ }^{137}$ Statistics in this section were provided by WSD staff on December 10, 2003.

${ }^{138}$ Family Forward is a statewide organization whose mission is to strengthen families and promote family stability through educational programs and support groups. Agency programs and services are provided through various direct service affiliates and community referral partners throughout the state of Texas. For more information, refer to Family Forward's website at http://www.familyforward.org/. (Accessed December 29, 2003.)

${ }^{139}$ This statistic is based on the total number of felons held in state prisons and state jails as of August 31, 2002 (6,911 women and 118,744 men were held in state prisons, and 3,230 women and 11,472 men were held in state jails at this time). This statistic does not include prisoners held in Substance Abuse Felony Punishment facilities, boot camps, or county jails because information about the gender of these prisoners was not available. (Source: Texas Department of Criminal Justice. 2003. Statistical Summary: Fiscal Year 2002, pp. 23, 38. Austin: Texas Department of Criminal Justice.) 
${ }^{140}$ Unless otherwise specified, all data presented in this section are the result of Urban Institute analysis of Criminal Justice Policy Council data that are available on that agency's website at http://www.cjpc.tx.state.us/ or the following two documents: Texas Board of Pardons and Paroles and Texas Department of Criminal Justice. 1998. Parole in Texas. Austin: Texas Board of Pardons and Paroles and Texas Department of Criminal Justice. http://www.tdcj.state.tx.us/publications/parole/parole_in_tx/pithome.htm. (Accessed January 2, 2004.); Parole Division. 2002. History of Parole in Texas. Austin: Texas Department of Criminal Justice, Parole Division. http://www.tdcj.state.tx.us/parole/parole-history.htm. (Accessed May 28, 2003.)

${ }^{141}$ In Texas, the sentencing judge can also approve discretionary release through shock probation, which allows a prisoner to serve the remainder of his or her sentence in the community under felony probation. ${ }^{142}$ Confinees released discretionarily through shock probation are not included in these percentages because these totals are aggregated with other sentence types and cannot be disaggregated, per a conversation with CJPC staff on June 9, 2003. However, CJPC staff explained that only a minimal percentage of confinees are released through shock probation.

${ }^{143}$ Due to the large number of prisoners considered for parole in Texas, a rare few appear before the panel for review.

${ }^{144}$ Prisoners who are sentenced to death or who are serving a sentence of life in prison without parole are ineligible for all forms of release discussed in this chapter and are therefore not noted in remaining sidebars.

${ }^{145}$ The governor, with the Texas Senate's approval, appoints the Board of Pardons and Paroles' 18 members, each of whom serves a six-year term. Historically, the Board was responsible for both release decisions and postrelease supervision. However, in 1989, the Texas legislature combined the Board and TDCJ. The Board retained control over its discretion to approve parole, set the conditions of release, and conduct parole violation proceedings, but TDCJ assumed responsibility for parole supervision and enforcement.

146 The time for good conduct earned by some prisoners incarcerated for some types of aggravated offenses does not count toward their parole-eligibility date.

${ }^{147}$ Prior to 1987, all prisoners were eligible for parole when their time served and credits for good behavior summed to one-third of their sentence length. In 1987, state legislation lowered the eligibility requirement from completion of one-third of the sentence to one-quarter of the sentence. Then, in 1993, the state legislature increased this requirement for some violent and aggravated offenders to one-third or to half of the sentence length and let the one-quarter requirement stand for nonviolent offenders. (Source: Senate Research Center. 1994. "Chronology of Texas Prison Reform 1972 to 1994," p. 8. Austin, TX: Senate Research Center.) For a complete listing of the required percentage of time served for each offender type and eligibility requirements, see Texas Board of Pardons and Paroles and Texas Department of Criminal Justice. 1998. Parole in Texas. Austin: Texas Board of Pardons and Paroles and Texas Department of Criminal Justice. http://www.tdcj.state.tx.us/publications/parole/parole_in_tx/pit-home.htm. (Accessed January 2, 2004.)

${ }^{148}$ Texas Board of Pardons and Paroles. 2002. 2001-2002 Texas Board of Pardons and Paroles Annual Report. Austin: Texas Board of Pardons and Paroles.

${ }^{149}$ When considering approval for parole, the Texas Board of Pardons and Paroles takes into account the following issues: "seriousness of the offense(s), sentence length and amount of time served, offender's age, juvenile history, criminal history (prior probation/parole), number of prison incarcerations, other arrests, institutional adjustment, and letters of support and/or protest." (Source: Texas Board of Pardons and Paroles. 2003. "Parole/MS Information." http://www.tdcj.state.tx.us/bpp/what_is_parole/first_page.htm. (Accessed December 10, 2003.)

${ }^{150}$ The total number of parolees includes prisoners released through parole in absentia (prisoners released to parole from non-TDCJ facilities).

${ }^{151}$ State prisoners earn credits for good behavior by participating in programs and avoiding disciplinary citations. Many state prisoners receive one day of credit for good behavior for each day served, but the TDCJ Board may increase or decrease the amount of credit providing the minimum statutory requirements for the offense are met.

${ }^{152}$ For a full review of all offenses that prevent Texas prisoners from being eligible for parole or mandatory supervision, see Texas Board of Pardons and Paroles and Texas Department of Criminal Justice. 1998. 
Parole in Texas. Austin: Texas Board of Pardons and Paroles and Texas Department of Criminal Justice. http://www.tdcj.state.tx.us/publications/parole/parole_in_tx/pit-home.htm. (Accessed January 2, 2004.)

${ }^{153}$ For those state prisoners sentenced before September 1 , 1996, TDCJ continues to award good-time credits automatically. This mechanism for release is described under "Release to Mandatory Supervision."

${ }^{154}$ Per telephone conversation with Criminal Justice Policy Council staff on July 8, 2003.

${ }^{155}$ State prisoners sentenced on or before September 1, 1996, are released automatically (not discretionarily) to mandatory supervision when their credits for good behavior and time served sum to their sentence length (mandatory supervision); those sentenced after this date may be denied mandatory supervision release by the Board of Pardons and Paroles (discretionary mandatory supervision). Currently, half of all mandatory supervision releases are discretionary: in 2002, 8,945 state prisoners were released through DMS and 8,407 were released through MS.

${ }^{156}$ Prisoners released from boot camps or those who received split sentences or a probation modification sentence receive probation supervision upon release. For an overview of boot camps, please refer to Research, Evaluation, and Development Unit. (n.d.) Boot Camp Analysis. Austin: Texas Department of Criminal Justice, Research, Evaluation, and Development Unit. http://www.tdcj.state.tx.us/. Split sentences (also referred to as "up-front time") are those that require both a period of incarceration and a period of probation after release; probation modification differs from split sentences only in that the offender receives the sentence for violating probation rather than a new offense. Offenders receive all three of these types of sentences at the time of sentencing, and they are therefore not considered a discretionary form of release.

${ }^{157} \mathrm{CJPC}$ reported the total number of confinees who were not classified to a release category. Between 2000 and 2002, the percentage of confinee releases who were unclassified totaled between 0.2 and 6.1 percent of all releases. The actual numbers of confinees in each category were estimated by applying the percentage of each category to the total number of unclassified confinees.

${ }^{158}$ The national statistic (77 percent) is based on the analysis of 2000 data. Timothy Hughes, Doris James Wilson, and Allen J. Beck. 2001. "Trends in State Parole, 1990-2000." Bureau of Justice Statistics Special Report. Washington, DC: U.S. Department of Justice, Bureau of Justice Statistics. See chapter 4 for further detail on mandatory supervision.

${ }^{159}$ For further details, see Criminal Justice Policy Council. 2003. "State Jail Releases, Fiscal Years 1988 to 2002.” In Statistical Tables: Parole and Time Served, p. 16. Austin, TX: Criminal Justice Policy Council.

${ }^{160}$ The number of TDCJ releases totaled 33,428 in 1988 and 58,949 in 2002.

${ }^{161}$ Most of Texas's parolees $(80,602)$ are on active parole supervision, meaning that they are required to report directly to a parole officer. Inactive parolees could include those who are parole absconders, "supervised out of state, deported, on detainer, in federal custody, and in out-of-state custody." (Source: Criminal Justice Policy Council. 2003. "Parole and Mandatory Supervision Populations, Fiscal Years 1988 to 2002." In Statistical Tables: Parole and Time Served, p. 15. Austin, TX: Criminal Justice Policy Council.

${ }^{162}$ The average caseload of parolees under intensive supervision was 23 , and the average caseload of parolees under super-intensive supervision was 15, per telephone conversation with Criminal Justice Policy Council staff on July 8, 2003.

${ }^{163}$ Prisoners not released through mandatory supervision or parole are given $\$ 100$ immediately upon release.

${ }^{164}$ TDCJ's PPTs include the Bridgeport (200 beds), Lockhart (500 beds), and Mineral Wells (2,100 beds), per conversation with Criminal Justice Policy Council staff on July 15, 2003. Also see Texas Department of Criminal Justice. 2003. Statistical Report Fiscal Year 2002, p. 1. Austin: Texas Department of Criminal Justice, Executive Services.

${ }^{165}$ Texas Board of Pardons and Paroles. 2002. 2001-2002 Texas Board of Pardons and Paroles Annual Report, p. 157. Austin: Texas Board of Pardons and Paroles.

${ }^{166}$ Information provided by the Texas Department of Criminal Justice Parole Division, Open Records Division, September 25, 2003.

${ }^{167}$ Texas Board of Pardons and Paroles. 2002. 2001-2002 Texas Board of Pardons and Paroles Annual Report, p. 159. Austin: Texas Board of Pardons and Paroles.

${ }^{168}$ Information provided by the Texas Department of Criminal Justice Parole Division, Open Records Division, September 25, 2003. 
${ }^{169}$ When an ex-prisoner cannot cover his or her fines and fees, a manageable long-term payment plan is developed. If the ex-prisoner refuses to pay these charges, then he or she may be required to participate in community service or may be sentenced to jail. See Texas Senate News. 2000. "Senate Committee on Criminal Justice Held Public Hearing at State Capitol." Texas Senate News, April 18.

${ }^{170}$ In 1985, the Texas legislature required that the Board of Pardons and Paroles develop guidelines to assess parolees' risk levels. At the recommendation of the Criminal Justice Policy Council and the National Institute of Corrections, a consulting firm recently revised these guidelines; parole officers began using them in 2001. (Source: Criminal Justice Policy Council. 2003. An Overview of Texas Parole Guidelines, December 2001. Austin, TX: Criminal Justice Policy Council.)

${ }^{171}$ For a full review of the requirements of each supervision level, refer to Texas Board of Pardons and Paroles and Texas Department of Criminal Justice. 1998. Parole in Texas. Austin: Texas Board of Pardons and Paroles and Texas Department of Criminal Justice.

http://www.tdcj.state.tx.us/publications/parole/parole_in_tx/pit-home.htm. (Accessed January 2, 2004.)

172 This national statistic comes from U.S. and state admissions in 1999, the most recent year that it is available. In 1999, probation and parole revocations made up 56 percent of all TDCJ admissions. (Source: Jeremy Travis and Sarah Lawrence. 2002. Beyond the Prison Gates: The State of Parole in America. Washington, DC: Urban Institute Press.)

${ }^{173}$ The source of the information provided in this paragraph is: Fabelo, Tony. 2000. "Presentation to House Corrections Committee: Parole Blue Warrant Process and Issues for Review." Presented on July 11, 2000, in Austin, TX. http://www.cjpc.state.tx.us/reports/parprob/BlueWarr6_00.pdf. (Accessed March 1, 2004.)

${ }_{174}^{174}$ An extension of an additional month is possible.

${ }^{175}$ Thirty-seven percent of all revocation hearings were due to technical violations.

${ }^{176}$ Data that would indicate the frequency of time served in the community not counting toward the sentence are not available.

${ }^{177}$ Information provided by the Texas Department of Criminal Justice Parole Division, Open Records Division, September 25, 2003.

${ }^{178}$ Unless otherwise noted in this chapter, the reported statistics are based on an Urban Institute analysis of Texas Department of Criminal Justice data (please refer to the introduction for more information on these data), including statistics that describe the state and counties to which prisoners returned following release. The data set provided by TDCJ listed the return state for nearly all prisoners $(55,156$ of 55,183$)$. Much of the analysis in this chapter centers on those prisoners returning to Texas. Of the 55,156 prisoners whose return state was recorded in the data set, 54,645 were listed to be returning to Texas. The state and county to which the prisoner was returning was available for 65 percent of all prisoners in the data set; the state and county of the remaining 35 percent of the prisoners were approximated by the state and county of conviction. These data were unavailable for less than 1 percent of prisoners.

${ }^{179}$ Please note that the information reported for "supervised releasees" does not include information for the less than 2 percent of prisoners released to probation.

${ }^{180}$ Per telephone conversation with staff of the Wayback House on February 19, 2004.

${ }^{181}$ Per telephone conversation with staff of CSC, Inc., on February 19, 2004.

${ }^{182}$ Per telephone conversation with staff of Salvation Army on February 19, 2004.

${ }^{183}$ Per telephone conversation with staff of SCS, Inc., on February 19, 2004.

${ }^{184}$ U.S. Census Bureau. 2000. Summary File 1 (SF-1). Profile of General Demographic Characteristics: 2000. Washington, DC: U.S. Department of Commerce, U.S. Census Bureau.

http://quickfacts.census.gov/qfd/states/24000.html. (Accessed November 11, 2003.); Bureau of Labor

Statistics. Labor Force Data by County, 2001 Annual Averages. Washington, DC: U.S. Department of

Labor, Bureau of Labor Statistics.

${ }^{185}$ Per telephone conversation with staff of the Reid facility on February 19, 2004.

${ }^{186}$ Please note that this Harris County return rate differs from the Harris County return rate listed in figure 6.1 because this return rate is based only on ex-prisoners released to Harris County who are also supervised and the latter rate is based on all ex-prisoners released to Harris County.

${ }^{187}$ One-fifth of supervised releasees returning to Houston were married.

${ }^{188}$ Lynch and Sabol. 2001. "Prisoner Reentry in Perspective"; Dina R. Rose and Todd R. Clear. 1998. "Incarceration, Social Capital, and Crime: Implications for Social Disorganization Theory." Criminology (36):441-79; Dina R. Rose and Todd R. Clear. 2003. "Incarceration, Social Capital, and Crime:

Implications for Social Disorganization Theory." In Prisoners Once Removed: The Impact of Incarceration 
and Reentry on Children, Families, and Communities, edited by Jeremy Travis and Michelle Waul (313342). Washington, DC: Urban Institute Press.

${ }^{189}$ Because the zip code 77004 spanned these two neighborhoods, we added their populations together to calculate the number of returning prisoners per 1,000 residents. Both the Third Ward and MacGregor contain parts of other zip codes that could increase the number (and rate) of returning prisoners. Specifically, zip code 77021, which is part of the MacGregor neighborhood, received an estimated 162 returning prisoners. However, since most of this zip code is not in the MacGregor neighborhood, we cannot be sure how many of the 162 prisoners actually returned to MacGregor. This same logic was applied to another zip code (77016) that spanned two neighborhoods - East Little York/Homestead and Trinity/Houston Gardens.

${ }^{190}$ Elycia Daniel, a doctoral student at Sam Houston University, compiled the information on social services in Houston that targeted ex-offenders. Ms. Daniel began by searching the "Ex-Offender/Prisoner" category in the 211 Texas database, a comprehensive database of social services in Texas compiled by the United Way. Ms. Daniel also located resources through the Texas Commission on Alcohol and Drug Abuse treatment service locator available on the agency's website at http://www.tcada.state.tx.us/. In addition, she performed an Internet-based search across related categories, including shelters, transitional living centers, rehabilitation programs, and ex-prisoner programs. Additional services were located through a TDCJ chaplain who was able to provide a list of churches in Houston that offer spiritual and other types of support to ex-offenders. Ms. Daniel also reviewed the Houston telephone book for other programs and services for prisoners, such as rehabilitation and counseling services. Ms. Daniel contacted TDCJ staff in Huntsville, who reported that no community resource list was available. 



\section{A P P E N DIX A \\ Comparison of Characteristics of Ex-prisoners Returning to Harris County by Postrelease Supervision (or Availability of Zip Code Data)}

Chi-square tests of each variable demonstrated a statistically significant correlation with postrelease supervision $(p<.05)$.

\begin{tabular}{|c|c|c|c|c|}
\hline & \multicolumn{2}{|c|}{$\begin{array}{l}\text { Postrelease supervision } \\
\text { (zip-code data available) }\end{array}$} & \multicolumn{2}{|c|}{$\begin{array}{l}\text { No postrelease supervision } \\
\text { (no zip-code data available) }\end{array}$} \\
\hline & $\mathrm{N}$ & $\%$ & $\mathrm{~N}$ & $\%$ \\
\hline \multicolumn{5}{|l|}{ Gender } \\
\hline Male & 5,784 & 87.7 & 6,467 & 85.8 \\
\hline Female & 809 & 12.3 & 1,069 & 14.2 \\
\hline \multicolumn{5}{|l|}{ Race } \\
\hline Black & 3,095 & 46.9 & 3,288 & 43.6 \\
\hline White & 2,950 & 44.7 & 2,877 & 38.2 \\
\hline Hispanic & 542 & 8.2 & 1,349 & 17.9 \\
\hline Other/unknown & 8 & 0.1 & 28 & 0.4 \\
\hline \multicolumn{5}{|l|}{ Marital status } \\
\hline Single & 4,648 & 71.8 & 5,311 & 75.2 \\
\hline Married & 1,509 & 23.3 & 1,407 & 19.9 \\
\hline Separated & 321 & 5.0 & 342 & 4.8 \\
\hline \multicolumn{5}{|l|}{ Offense } \\
\hline Property & 2,222 & 33.7 & 2,482 & 32.9 \\
\hline Drug & 2,211 & 33.5 & 2,884 & 38.3 \\
\hline Violent & 1,115 & 16.9 & 1,303 & 17.3 \\
\hline DWI & 620 & 9.4 & 371 & 4.9 \\
\hline Other & 299 & 4.5 & 345 & 4.6 \\
\hline Weapons & 125 & 1.9 & 107 & 1.4 \\
\hline \multicolumn{5}{|l|}{ Sentence length } \\
\hline Less than 1 year & 0 & --- & 1,747 & 23.4 \\
\hline 1 to 2 years & 813 & 12.3 & 2,098 & 28.1 \\
\hline 2 to 3 years & 579 & 8.8 & 445 & 6.0 \\
\hline 3 to 5 years & 1,333 & 20.2 & 821 & 11.0 \\
\hline 5 to 10 years & 2,013 & 30.5 & 1,124 & 15.1 \\
\hline over 10 years & 1,855 & 28.1 & 1,228 & 16.5 \\
\hline \multicolumn{5}{|l|}{ Time Served } \\
\hline less than $20 \%$ & 219 & 3.3 & 2,991 & 40.7 \\
\hline $20 \%$ to $40 \%$ & 1,563 & 23.7 & 999 & 13.6 \\
\hline $40 \%$ to $60 \%$ & 2,933 & 44.5 & 1,727 & 23.5 \\
\hline $60 \%$ to $80 \%$ & 1,217 & 18.5 & 615 & 8.4 \\
\hline $80 \%$ to $100 \%$ & 661 & 10.0 & 1,025 & 13.9 \\
\hline
\end{tabular}

Source: Urban Institute analysis of TDCJ data.

Note: Percentages may not sum to 100 percent due to rounding. 



\section{A P P E N D IX B Overview of Probation}

Prisoners can be released to probation via a split sentence, shock probation, boot camp, or probation modification. ${ }^{1}$ The sentencing judge sets the conditions of release and TDCJ's Community Justice Assistance Division (CJAD) oversees 121 local departments (called Community Supervision and Corrections Departments, which are overseen by the local judiciary) that are spread throughout Texas's 254 counties and that supervise probationers. ${ }^{2}$ The total percentage of all TDCJ prisoners released to probation has remained relatively low for the past decade; in 1988, close to 3 percent (or 997 of 38,041) of all TDCJ prisoners were released to probation compared to slightly more than 2 percent in $2002(1,512$ of 58,949$)$.

\section{CASELOADS}

From 1988 to 1994, Texas's felony, direct supervision probation population increased markedly (by 65 percent, from 92,311 to 152,624 ) and then largely leveled off, totaling 158,493 in 2002 . $^{3}$ On average, a probation officer is responsible for 116 direct-supervision probationers (data on the average caseload at earlier dates are not available). ${ }^{4}$ A probation officer with a specialized caseload has an average caseload of 56 direct-supervision probationers. ${ }^{5}$ This caseload allows the officer to devote an average of 51 minutes to each probationer each month. ${ }^{6}$

\section{CONDITIONS OF RELEASE}

Postrelease supervision always involves a set of release conditions, requirements that the prisoner is obligated to fulfill as a condition of his or her release to the community. Some release conditions are standard components of supervision while others are tailored to address a particular offender's needs. Failing to fulfill all release conditions can, at a minimum, lead to sanctions and, at a maximum, can lead to supervision revocation and reincarceration.

With probation, the judge typically establishes prisoners' conditions of release when he approves them for shock probation release (those probationers released from a community corrections facility may have been assigned to aftercare programs). A typical probationer is required to (1) comply with the law; (2) avoid "injurious and vicious habits"; (3) avoid contact with persons and areas of "disreputable and harmful character"; (4) report to the probation officer; (5) allow the probation officer to come in the home or another location; (6) work; (7) remain within a specified county; (8) pay, if applicable, fines, fees, child support, the cost of their court-appointed attorney, $\$ 100$ to the victim, the law enforcement costs resulting from the handling and disposing of any materials collected in the case, the cost of the victim's counseling, 
and up to $\$ 50$ to Crimestoppers; (9) participate in a program; and (10) be tested for use of illicit substances. $^{7}$

The judge may also require the ex-prisoner to abide by special conditions. The most frequently ordered conditions include residence in a halfway house, adherence to sex offender requirements, intensive supervision, electronic monitoring, drug testing, participation in treatment or educational programs, and counseling. ${ }^{8}$ The judge may also require that the prisoner reside in one of CJAD's 36 community correctional facilities, about half of which focus on substance abuse treatment. With a capacity of 3,030 beds, these centers served 12,335 probationers in 2002 . Slightly more than half of those served participated in substance abuse treatment centers (see table B. 1 for disaggregation by facility type). ${ }^{9}$

Table B.1. Community corrections facilities, capacity, and usage for probationers, FY 2002

\begin{tabular}{lrr}
\hline \multicolumn{1}{c}{ Facility type } & Bed capacity & Total served \\
\hline All residential substance abuse treatment programs & 1,404 & 6,619 \\
Intermediate sanction facility & 422 & 2,078 \\
Local boot camps & 480 & 1,446 \\
Restitution centers & 724 & 2,192 \\
Total & $\mathbf{3 , 0 3 0}$ & $\mathbf{1 2 , 3 3 5}$ \\
\hline
\end{tabular}

Source: Community Justice Assistance Division.

Like parolees, probationers make significant contributions in time and earnings. In 2001, probationers provided 9.4 million hours in community service, which is worth around $\$ 49$ million if valued at minimum wage. ${ }^{10}$ Also in 2001, the CSCDs collected $\$ 237$ million in fees from probationers. Almost half of these fees ( $\$ 112$ million) were used to cover around a third of the cost of administering probation; $\$ 68$ million was distributed to state and county agencies; and $\$ 47$ million was devoted to victim compensation. ${ }^{11}$ On average, probationers paid $\$ 30$ each in fees per month. ${ }^{12}$ Probation officers reported that fee collection accounted for approximately 20 percent of their time. ${ }^{13}$ Based on a sample of probationers in six counties, most (75 percent) are employed in full-time positions and are therefore able to pay these fines; their median annual salary is $\$ 18,200 .{ }^{14}$ In a TDCJ-CJAD survey, about half of all CSCD directors reported that 50 percent of all probationers have trouble making their payments and 17 percent are unable to make their payments. ${ }^{15}$

\section{INTENSITY OF SUPERVISION}

The intensity of a prisoner's postrelease supervision depends on the estimated risk that he poses to public safety given his background, reentry challenges, and other individual characteristics. In short, the greater the risk an offender poses, the greater the intensity of supervision he receives. To determine a prisoner's risk, both probation and parole officers use standardized assessment 
tools. ${ }^{16}$ Following is a description of the various levels of supervision administered through probation.

Local Community Supervision Correction Departments (CSCD) have either three or four levels of supervision. Very low-risk probationers are supervised under level I, low risk probationers are supervised under level II, medium-risk probationers are supervised under level III, high-risk probationers are supervised under level IV, and very high-risk probationers are supervised under level V. ${ }^{17}$ The only requirement by the state is that probationers meet with probation officers once every 90 days; CSCDs then set the requirements entailed in each supervision level. Most felony probationers receive level III supervision. The requirements entailed in this level and other levels are determined locally by each CSCD.

\section{REVOCATIONS}

Sentences to prison for felony probation revocations ${ }^{19}$ steadily increased between 1988 and 2002, rising from 13,900 to 21,485 . Although the probation revocation rate remained stable, the growth in the felony probation population caused the increase in total revocations. In 2002, probation revocations accounted for 32 percent of all TDCJ admissions. Broken down by TDCJ facility type, they accounted for 32 percent of all state prison admissions and 33 percent of all state felony jail admissions.

Technical violations constitute a growing percentage of felony probation revocations: in 1993, 42 percent of all such revocations were for technical violations and, by 1999, 55 percent were. ${ }^{20}$ Since 1999 , the percentage of technical violations has plateaued. ${ }^{21}$ The primary reasons for the majority (63 percent) of technical violations were two or more positive drug tests, incompletion of treatment, failure to appear at scheduled meetings, and noncompliance with restrictions (such as sex

A Barrier to Greater Use of Alternatives to Revocation

Three-quarters of district attorneys and district judges stated that they would be more likely to use probation as an alternative to revocation if additional communitybased residential beds were available. $^{18}$ But, in spite of the growth in the probation population, the capacity of community corrections facilities has fallen from 4,571 beds in 1995 to 2,735 beds in 2002. At any given time, approximately 832 men and 371 women are awaiting placement into these facilities with an average wait time of 2.6 months and 4.9 months, respectively.

offender requirements and electronic monitoring). ${ }^{22}$ Nearly all technical violators were delinquent in repayment of fees (on average $\$ 1,923$ ), but less than 1 percent were revoked solely for this reason. When probation is revoked for a technical violation, the probationer serves the full term of incarceration; time served on probation in the community does not count toward the sentence unless the judge reduces the original sentence accordingly. ${ }^{23}$

The local prosecutor or the probation officer may begin the probation revocation process. ${ }^{24}$ Although local processes may differ, generally the local prosecutor or the CSCD files a "motion to revoke," a warrant or a certified letter is given to the probationer, and a hearing is arranged. At the hearing, the probationer pleads either "true" or "not true." If the probationer 
pleads the latter, a trial is arranged. If the probationer pleads the former, his probation may be revoked, he may remain on probation supervision after incarceration, he may be placed in a community corrections facility, or the motion to revoke could be dismissed.

As an alternative to sending probation violators to prison or state jail, judges can place them in intermediate sanction facilities, court residential treatment centers, substance abuse treatment facilities, restitution centers, substance abuse felony punishment facilities, boot camps, and halfway houses. In 2001, 9,913 probationers were served in these community corrections facilities (includes probationers who were not violators) while 9,116 were sent to state jail and 11,594 were sent to prison for violations (figure B.1). ${ }^{25}$ The average cost of placing a revoked probationer in a community corrections facility totaled $\$ 6,177$, while CJPC reported that the average cost of revocation to state jail was $\$ 8,448$ and $\$ 40,538$ to state prison.

Figure B.1. Probation revocations as a percentage of TDCJ admissions, FY 1988 to FY 2002

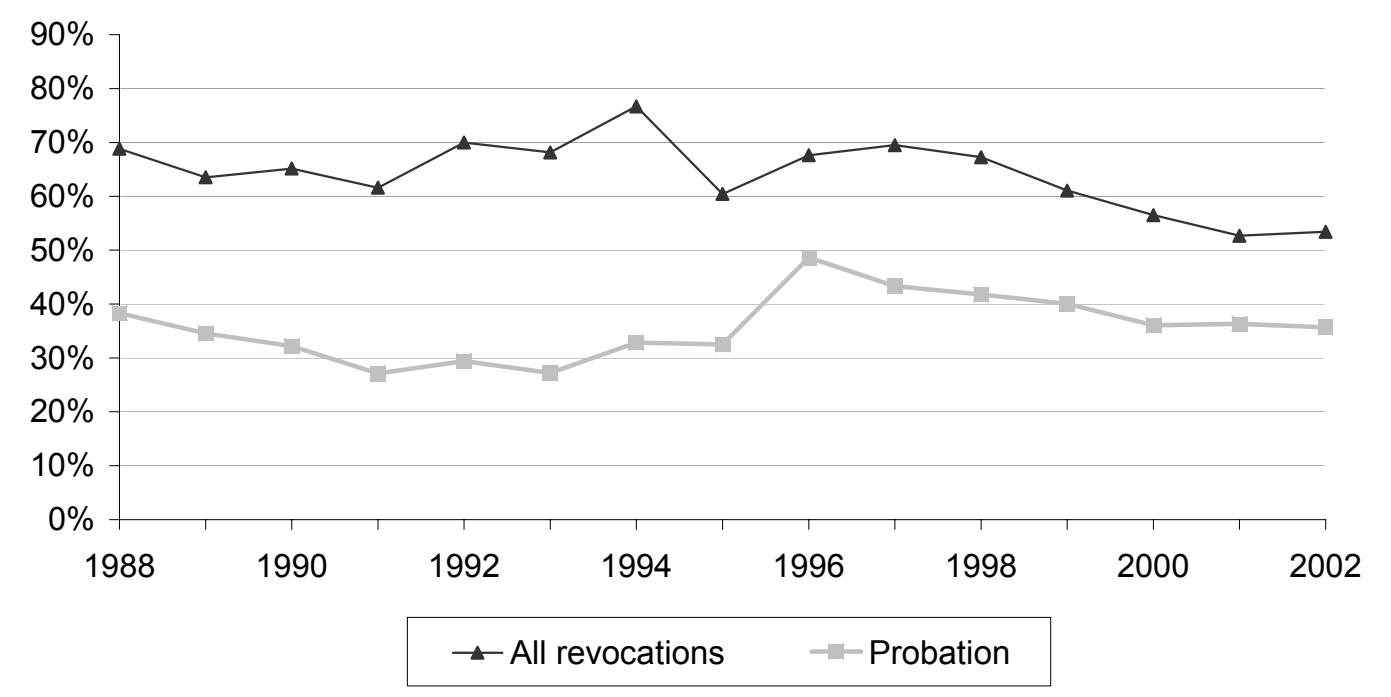

Source: Urban Institute analysis of Criminal Justice Policy Council data. 


\section{Appendix B Notes}

\footnotetext{
${ }^{1}$ The number of confinees given split sentences is small (390, or 1.8 percent of all state jail releases in 2002). Although the total number is not available, the number of state prisoners given split sentences is estimated to be small as well, per a conversation with Criminal Justice Policy Council staff in April 2003. A split sentence is not considered discretionary because the judge awards probation at the time of sentencing rather than during the prisoner's incarceration (with consideration of the prisoner's institutional behavior).

${ }^{2}$ The state provides two-thirds of all funding (probationers pay the rest), oversight, and technical assistance; and counties provide office space, equipment, and administrative assistance. For more information, see the Texas Department of Criminal Justice's Community Justice Assistance Division website, http://www.tdcj.state.tx.us/cjad/cjad-home.htm. (Accessed December 31, 2003.)

${ }^{3}$ Direct supervision probationers are those who are on probation, live or are employed in the area in which they are supervised, and have at least one in-person contact with a probation officer every three months. Indirect supervision probationers are on probation but never report in person to a probation officer "because they have transferred out of their original CSCD or county to another state, another CSCD, or county; they report by mail; they have absconded; or they are incarcerated in county jail, prison, or State Jail (and they have a term of community supervision to complete upon release from incarceration)." (Sources: Criminal Justice Policy Council. 2003. "Parole and Mandatory Supervision Population, Fiscal Years 1988 to 2002." In Statistical Tables: Parole and Time Served, p. 15. Austin, TX: Criminal Justice Policy Council; Criminal Justice Policy Council. 2003. "Total Direct Probation Supervision Population, Fiscal Years 1988 to 2002." In Statistical Tables: Probation, p. 15. Austin, TX: Criminal Justice Policy Council.)

${ }^{4}$ These probationers are under direct supervision, which is comparable to active parole. A typical probation officer also has 36 probationers who are under indirect supervision. A probation officer has a smaller caseload if it includes more probationers that are on active supervision (meaning the probationers report directly to the probation officer) than on inactive supervision.

${ }^{5}$ On average, an officer with a specialized caseload is also responsible for 19 indirect supervision probationers.

${ }^{6}$ TexaSuperVision. 2002. Probation: Legislative Overview, pp. 2-3. Austin, TX: TexaSuperVision.

${ }^{7}$ For a full list, see Larry Gist. 2002. Summary and Citation: Statutory Probation Conditions. February. Unpublished document.

${ }^{8}$ Texas Board of Pardons and Paroles and Texas Department of Criminal Justice. 1998. Parole in Texas. Austin: Texas Board of Pardons and Paroles and Texas Department of Criminal Justice. http://www.tdcj.state.tx.us/publications/parole/parole_in_tx/pit-home.htm. (Accessed January 2, 2004.)

${ }^{9}$ Residential substance abuse treatment programs include court residential treatment centers, substance abuse treatment facilities, and residential substance abuse treatment facilities. Additionally, 145 probationers resided in a community corrections halfway house and 65 resided in facilities for offenders with mental impairments; data for the total number of beds available in these facilities were not provided. (Source: Wynde L. Jones. 2003. Community Supervision in Texas: Summary Statistics, pp. 26-27. Austin: Texas Department of Criminal Justice, Community Justice Assistance Division, Research and Evaluation.) ${ }^{10}$ Bonita White. 2003. "Overview of Community Supervision in the Context of a Budget Crisis," p. 12. Austin, TX: Presentation to the House Committee on Corrections Interim Committee on February 18. http://www.tdcj.state.tx.us/publications/cjad/fact-sheets/House_Report_2-18-03.pdf. (Accessed January 2, 2004.)

${ }^{11}$ TexaSuperVision. 2002. Community Supervision: Legislative Overview, pp. 2-3. Austin, TX: TexaSuperVision.

${ }^{12}$ Per TDCJ Community Justice Assistance Division staff on August 26, 2003.

${ }^{13}$ TexaSuperVision. 2002. Community Supervision: Legislative Overview, p. 3. Austin, TX: TexaSuperVision.

${ }^{14}$ Seventeen percent of probationers were unemployed, 7 percent worked in part-time positions, and 1 percent performed seasonal work. The sample may not be representative; it includes Galveston, Fort Bend, Hood, Jasper, Jack, and Wise CSCDs. (Source: Bonita White. 2002. "An Overview of Community
} 
Correction Fees Collected by Community Supervision and Corrections Departments," pp. 11-12. Austin, TX: Presentation to the House Committee on Corrections Interim Committee on April 2. http://www.tdcj.state.tx.us/publications/cjad/fact-sheets/House_Report_Fees_Final_4-02-02.pdf. [Accessed January 2, 2004.])

${ }^{15}$ Texas Department of Criminal Justice and the Community Justice Assistance Division. 2002. Fee Collections in Community Supervision and Corrections Departments. Austin: Texas Department of Criminal Justice and the Community Justice Assistance Division.

${ }^{16}$ In 1985, the Texas legislature required that the Board of Pardons and Paroles develop guidelines to assess parolees' risk levels. At the recommendation of the Criminal Justice Policy Council and the National Institute of Corrections, a consulting firm recently revised these guidelines; parole officers began using them in 2001. (Source: Criminal Justice Policy Council. 2003. An Overview of Texas Parole Guidelines, December 2001. Austin, TX: Criminal Justice Policy Council.)

${ }^{17}$ Per TDCJ Community Justice Assistance Division, Research and Evaluation unit staff on August 26, 2003.

${ }^{18}$ Texas Department of Criminal Justice, Community Supervision and Corrections Departments, and Judicial Advisory Council. 2002. Texas Residential Programs Community Corrections Facilities, p. 7. Report to House Corrections Interim Committee in Austin, TX, on July 16.

${ }^{19}$ Includes probationers who were placed on probation as part of a split sentence and those who were placed on probation alone; however, few probationers are expected to have been given a split sentence since these types of sentences are rarely awarded.

${ }^{20}$ Wynde L. Jones. 2000. Community Supervision in Texas: Summary Statistics. Austin: Texas Department of Criminal Justice, Community Justice Assistance Division, Research and Evaluation.

${ }^{21}$ Per TDCJ Community Justice Assistance Division, Research and Evaluation unit staff on August 26, 2003.

${ }^{22}$ Criminal Justice Policy Council. 2002. "Trends, Profile, and Policy Issues Related to Felony Probation Revocations in Texas. Austin, TX: Criminal Justice Policy Council.

${ }^{23}$ Ibid.

${ }^{24}$ All information describing the probation revocation process was obtained from TDCJ Community Justice Assistance Division, Research and Evaluation unit staff on August 26, 2003.

${ }^{25}$ The total number of probationers diverted from state prison and state jail for violations is unknown and difficult to estimate, per TDCJ Community Justice Assistance Division, Research and Evaluation unit staff, August 26, 2003. 